UNIVERSIDADE DE SÃO PAULO

FFCLRP - DEPARTAMENTO DE BIOLOGIA

PROGRAMA DE PÓS-GRADUAÇÃO EM BIOLOGIA COMPARADA

\title{
Variabilidade genética e morfológica em populações de Trichodactylus fluviatilis Latreille, 1828 (Brachyura, Trichodactylidae).
}

Edvanda Andrade Souza de Carvalho

Dissertação apresentada à Faculdade de Filosofia, Ciências e Letras de Ribeirão Preto da USP, como parte das exigências para a obtenção do título de Mestre em Ciências, Área: Biologia Comparada

Ribeirão Preto/SP

2013 
UNIVERSIDADE DE SÃO PAULO

FFCLRP - DEPARTAMENTO DE BIOLOGIA

PROGRAMA DE PÓS-GRADUAÇÃO EM BIOLOGIA COMPARADA

\title{
Variabilidade genética e morfológica em populações de Trichodactylus fluviatilis Latreille, 1828 (Brachyura, Trichodactylidae).
}

\author{
Edvanda Andrade Souza de Carvalho
}

Orientador: Prof. Dr. Fernando L. M. Mantelatto

\begin{abstract}
Dissertação apresentada à Faculdade de Filosofia, Ciências e Letras de Ribeirão Preto da USP, como parte das exigências para a obtenção do título de Mestre em Ciências, Área: Biologia Comparada
\end{abstract}

\section{Versão Corrigida}

Ribeirão Preto/SP

2013 
Autorizo a reprodução e divulgação total ou parcial deste trabalho, por qualquer meio convencional ou eletrônico, para fins de estudo ou pesquisa, desde que a fonte seja citada.

Souza-Carvalho, Edvanda, A.

Variabilidade genética e morfológica em populações de Trichodactylus fluviatilis Latreille, 1828 (Brachyura, Trichodactylidae)./Edvanda Andrade Souza de Carvalho; orientador: Fernando Luis Medina Mantelatto.

Ribeirão Preto, 2013

$\mathrm{XIV}+83 \mathrm{f}$

Dissertação (Mestrado - Programa de Pós-graduação em Ciências. Área de concentração: Biologia Comparada). Faculdade de Filosofia, Ciências e Letras de Ribeirão Preto, Universidade de São Paulo.

1.Caranguejo de água doce 2. Complexo de espécies 3. Divergência genética 4.Variabilidade 
Ao meu amor, Fabrício Carvalho, por todo amor e compreensão. 
AGRADECIMENTOS 
Ao prof. Dr. Fernando Luis Medina Mantelatto, obrigada pela valiosa e imprescindível orientação durante estes dois anos de mestrado. Este período sob sua orientação foi muito bom e de extrema importância para meu crescimento científico e pessoal. Muito obrigada por ter me confiado um projeto tão lindo e importante; muito obrigada pela oportunidade de fazer parte da sua equipe, especialmente pela amizade, compreensão, carinho e confiança. Espero continuar trabalhando e aprendendo com você por um bom tempo. Muito, muito, muito obrigada por tudo.

Ao Programa de Biologia Comparada da Faculdade de Filosofia, Ciências e Letras de Ribeirão Preto (FFCLRP), por intermédio do Programa PROAP/CAPES e do coordenador prof. Dr. Ricardo Macedo Corrêa e Castro, pelo apoio financeiro que proporcionou a minha participação em congressos, disciplinas e visitas às coleções carcinológicas, e em especial as secretárias Vera Cassia Cicilini de Lucca e Renata Andrade Callavari, que sempre me receberam com muito carinho e por serem muito prestativas.

À Coordenação de Aperfeiçoamento Pessoal de Nível Superior (CAPES) pela concessão da minha bolsa de mestrado.

A Fundação de Amparo à Pesquisa do Estado de São Paulo (FAPESP) - Procs. 2010/50188-8 (Projeto Temático Biota), 2009/54931-0 (Projeto Coleções Científicas) e ao Conselho Nacional de Desenvolvimento Científico e Tecnológico (CNPq) - Procs. 490314/2011-2 (Projeto de Cooperação Internacional Brasil - Costa Rica), 471011/2011-8 (Edital Universal, Auxílio Individual a Pesquisa) pelo apoio financeiro concedido ao prof. Dr. Fernando Mantelatto que foram de fundamental importância para garantir o suporte financeiro ao desenvolvimento desta pesquisa.

Ao prof. Dr. Célio Magalhães, pela enorme e imprescindível ajuda, atenção e gentileza, para comigo durante todos os momentos que precisei. Minha enorme gratidão por todo conhecimento a mim transmitidos durante este tempo de parceria. $\mathrm{E}$ que venham mais parcerias. Muito obrigada Célio por tudo.

Ao meu amor, Fabrício, nem sei por onde começar. São tantos agradecimentos que infinitas páginas não seriam suficientes. Amor, meu super obrigada por todo companheirismo, ensinamentos, amor, dedicação, carinho, compreensão; por sempre me ouvir, estar ao meu lado em todos os momentos de minha vida, sejam estes bons ou ruins. Sem você este trabalho não seria o mesmo, pois você é o meu tudo. Obrigada por sempre acreditar e lutar juntamente comigo na realização de meus sonhos; obrigada por tornar a minha vida sempre mais feliz ao seu lado. 
À todos que contribuíram com doações e empréstimos de material: Dr. Rogério Costa (UNESP-Botucatu), Dr. Luis Ernesto Arruda Bezerra (UFERSA), Dra. Georgina Bond-Buckup (UFRGS), Dra. Paula Beatriz Araújo (UFRGS), Dra Odete Lopes (MHNCI), Dr. Marcos Tavares (MZUSP), Dr. Sérgio Bueno (IB-USP), Dra Irene Cardoso (MNRJ), em especial aos profs. Drs. Alexandre Almeida (UESC), Sérgio Rocha (UFRB) e Célio Magalhães (INPA) por toda disponibilidade de tempo e preocupação em ajudar com doações de material tão preciosos, para o desenvolvimento desta pesquisa.

Ao Dr. Alexandre Almeida e Fabiana Holanda pelo carinho de sempre e grande ajuda com alguns termos em francês contidos na descrição original de $T$. fluviatilis.

Ao Dr. Vinícius Renner Lampert (UFRGS) e a Msc. Larissa Corteletti da Costa (UVV) e Túlio Paiva (UESC) pela disponibilidade de tempo em coletar e doar exemplares, além de toda atenção.

À profa. Dra. Tiana Kohlsdorf, ao prof. Dr. Wagner Eustáquio Paiva Avelar e Dr. Leonardo Pileggi por todas as sugestões e contribuições durante a minha banca de qualificação.

Á Dra. Paula Rodriguez Moreno, diretora da coleção de crustáceos do Muséum National d'Histoire Naturelle (MNHN), pelas informações sobre o material-tipo e pela bibliografia disponibilizada.

Ao prof. Dr. Flávio Alicino Bockmann (FFCLRP/USP), profa. Dra. Setuko Masunari (UFPR) e Msc.Valéria Fernandes (UFV) pela ajuda em conseguir contatos que pudessem coletar ou emprestar animais.

Às técnicas Cláudia Aparecida Rodrigues (Claudinha) do Laboratório de Microscopia Eletrônica, e Márcia Fioresi Mataqueiro do Laboratório de Citogenética e Morfologia de Invertebrados da FCAV- UNESP, Jaboticabal, por terem ajudado na preparação do material e imagens dos gonópodos.

Ao técnico, Álvaro Costa (FFCLRP/USP), por toda ajuda durante as coletas e por toda gentileza em todos os momentos.

Ao prof. Dr. Fernando Zara (UNESP - Jaboticabal) por ter me recebido em seu laboratório, com muita gentileza e atenção, para a elaboração das analises de MEV. Obrigada por toda ajuda.

A Dra. Mariana Terossi (Mari) por toda ajuda com as técnicas moleculares, pelo carinho, amizade e atenção durante estes dois anos. Muito obrigada minha querida por sempre me apoiar e ajudar com todo carinho. 
Ao Dr. Rafael Robles e Msc. Nicole Olguin pelos ensinamentos e discussões durante meus estudos para a seleção do mestrado e no decorrer destes dois anos.

A todos os atuais companheiros e ex-integrantes da família LBSC: Natália Rossi, Mariana Negri (Kana), Mariana Terossi (Mari), Raquel Buranelli, Tatiana Magalhães (Tati), Ana Francisca Gomes (Kelps), Leonardo Pileggi, Rafael Robles, Mateus Lopes, Caio de Oliveira, Juliana Paixão, Bárbara Paz, Ana Vera, Lucas Zupollini, Natália Grilli, Camila Silveira, Douglas Peiró, Isabela Leone, Nicole Olguin, Emerson Mossolin, Ivana Miranda. Obrigada a todos vocês pela amizade, companheirismo, momentos de descontrações, ensinamentos, e principalmente por todo carinho com o que me acolheram desde o primeiro momento em que nos conhecemos.

À Msc. Gabriela Zanarotti, pelos ensinamentos e ajuda na molecular.

À Msc. Maíra Massarani pela confecção dos desenhos de Trichodactylus.

À Dra . Renata Biagi, por toda atenção e ajuda desde o primeiro momento em que visitei Ribeirão Preto.

À Msc. Renata Lima (Renatinha), por toda ajuda durante o momento em que fui visitar a coleção de crustáceos no INPA e no decorrer do mestrado. Muito Obrigada pelo carinho ao longo desse tempo.

À Msc. Natália Rossi e Msc. Tatiana Magalhães, pela linda amizade que construímos de muito carinho e confiança. Obrigada as duas por toda ajuda, generosidade, e principalmente por compartilhar momentos de muitas descontrações e seriedade, além da enorme atenção que tiveram comigo mesmo antes de vir morar em Ribeirão Preto. Obrigada minhas amigas tão queridas.

À Camila Silveira, pelo carinho de sempre.

À Msc. Nicole Olguin e Msc. Guilhermo Guzmán, por toda ajuda e grande carinho durante a minha visita ao Museu de Zoologia da USP em São Paulo.

À Msc. Ana Francisca Tamburus (Kelps) e seus pais por terem disponibilizados com muito carinho a sua casa para a realização da rodada de comida baiana em comemoração a minha primeira bolsa de mestrado.

À Mariana Negri (Kana), por toda compreensão, paciência e grande ajuda organizando as placas para os PCR de sequenciamentos.

À Juliana Paixão, Bárbara Prado, Caio Cruz e Ana Luiza que foram grandes parceiros nos trabalhos referentes à coleção de crustáceos do LBSC. 
Aos meus amados pais, obrigada por me amar incondicionalmente e sempre lutar para me dar uma vida maravilhosa. Sem vocês eu jamais teria conseguido chegar aqui. Obrigada meus amores por existirem em minha vida. 
O RIO ATINGE SEUS OBJETIVOS PORQUE APRENDEUA CONTORNAR SEUS OBSTÁCULOS (LAO TSÉ ). 


\section{SUMÁRIO}

RESUMO

ABSTRACT.

LISTA DE FIGURAS.

LISTA DE TABELAS.

LISTA DE ABREVIAÇÕES E SÍMBOLOS.

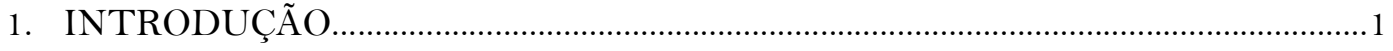

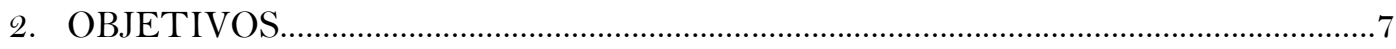

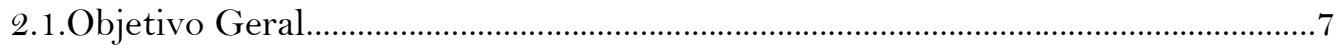

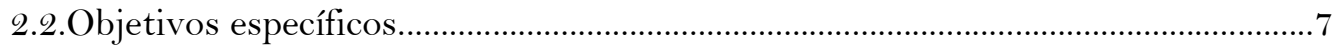

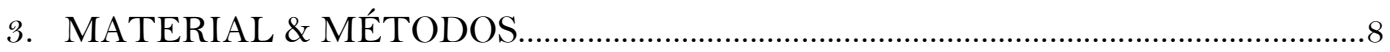

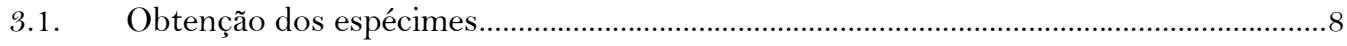

3.2. Obtenção dos dados moleculares...................................................................................

3.3. Obtenção dos dados morfológicos.................................................................................

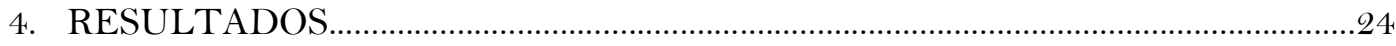

4.1. Análise molecular.................................................................................................... 24

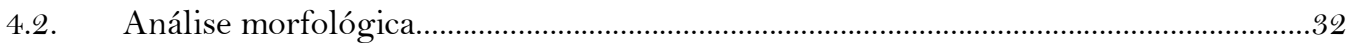

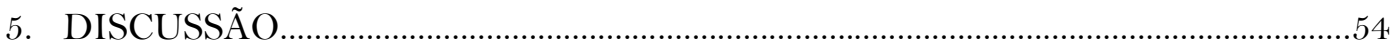

5.1. Relações filogenéticas.......................................................................................................54

5.2. Considerações taxonômicas........................................................................................5

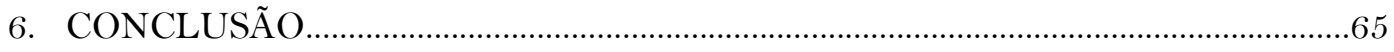

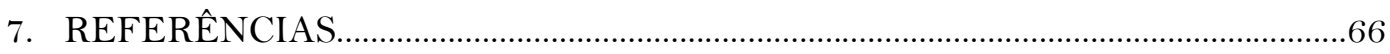

8. ANEXOS

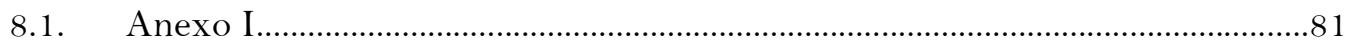

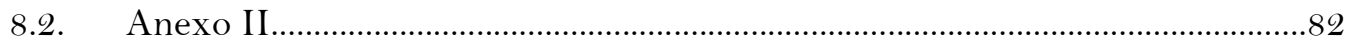

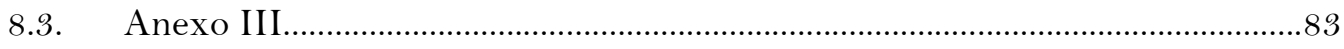




\section{RESUMO}


SOUZA-CARVALHO, E.A. 2013. Variabilidade genética e morfológica em populações de Trichodactylus fluviatilis Latreille, 1828 (Brachyura,

Trichodactylidae). 83f. Dissertação (Mestrado) - Faculdade de Filosofia, Ciências e Letras de Ribeirão Preto, Universidade de São Paulo, Ribeirão Preto.

O caranguejo de água doce Trichodactylus fluviatilis Latreille, 1828 apresenta uma considerável variabilidade morfológica, aliada a uma ampla distribuição geográfica e ocupação de ambientes costeiros e continentais. Tal variabilidade tem gerado, em alguns casos, dúvidas quanto à delimitação da espécie. O presente trabalho tem como objetivo averiguar se as populações de $T$. fluviatilis apresentam divergências morfológicas e genéticas compatíveis com o nível intraespecífico avaliando-se a hipótese de validade deste táxon. Para isto, foi realizada a análise da variabilidade genética entre as populações e uma revisão taxonômica. $\mathrm{O}$ material analisado foi obtido por meio de coletas, visitas e empréstimos de coleções carcinológicas do Brasil. Foram analisados caracteres descritos na literatura e obtidas sequências parciais dos genes mitocondriais 16S rRNA e citocromo c oxidase subunidade I (COI). Dentre os caracteres morfológicos analisados alguns tiveram muita variação, enquanto outros se mostraram bem informativos para alguns grupos. O resultado da análise molecular mostrou a formação de clados internos com altas divergências genéticas entre eles, tanto para o gene $16 \mathrm{~S}$ quanto para o COI. Além disso, a espécie T. petropolitanus foi alocada entre os clados reconhecidos morfologicamente como T. fluviatilis. Tais estruturações genéticas, aliada ao polimorfismo morfológico, mostraram claramente que a espécie reconhecida morfologicamente como $T$. fluviatilis não forma um grupo monofilético, podendo ser considerada um complexo de espécies, que precisa de ajustes taxonômicos consideráveis.

Palavras-chave: caranguejo de água doce, complexo de espécies, divergência genética, variabilidade. 
SOUZA-CARVALHO, E.A. 2013. Genetic and morphological variability in populations of Trichodactylus fluviatilis Latreille, 1828 (Brachyura, Trichodactylidae). 83f. Thesis (Master Science) - Faculty of Philosophy, Sciences and Letters at Ribeirão Preto (FFCLRP), University of São Paulo (USP), Ribeirão Preto.

The freshwater crab Trichodactylus fluviatilis Latreille, 1828 presents a considerable morphological variability, as well as a wide geographical distribution and occupancy of coastal and continental environments. Such variability has generated, in some cases, doubts concerning the species delimitation. The present work aims to investigate whether the populations of $T$. fluviatilis exhibit morphological and genetic divergence compatible with the intraspecific level, assessing the hypothesis of validity of this taxon. Therefore, we have performed the analysis of genetic variability among populations and a taxonomic revision. The material analyzed was obtained from field expeditions, visits and loans from carcinological collections. We analyzed morphological characters described in the literature as well as obtained partial sequences of the 16S rRNA and cytochrome c oxidase subunit I (COI) mitochondrial genes. Some morphological characters analyzed had a wide variation, while others were well informative for some groups. The results of molecular analysis showed the formation of internal clades with high genetic divergence among them, both for $16 \mathrm{~S}$ and COI. Moreover, the species T. petropolitanus was allocated among clades recognized morphologically as $T$. fluviatilis. Such genetic structuration and morphological polymorphism clearly indicate that the species morphologically recognized as $T$. fluviatilis does not form a monophyletic group. Therefore, it must be considered as a species complex, which claims for huge taxonomic adjustments.

Key-words: freshwater crab, genetic divergence, species complex, variability. 


\section{LISTA DE FIGURAS}

Figura 1. Exemplar de Trichodactylus fluviatilis do município de Ilhabela-SP. .5

Figura 2: Ambientes de coleta dos exemplares do complexo Trichodactylus fluviatilis. A: Porto Ferreira (SP); B: Prado (BA); C: Iconha (ES); D: Elísio Medrado (BA); E: Estância (SE); F: Camboriú (SC). 9

Figura 3. Desenho esquemático da morfologia externa do caranguejo Trichodactylus fluviatilis com destaque para as estruturas utilizadas na identificação da espécie (MNRJ 19149 ठ̊ $39.52 \mathrm{~mm}$ ) 22

Figura 4. Desenho esquemático da morfologia de um gonópodo do caranguejo Trichodactylus fluviatilis com destaque para algumas estruturas utilizadas na identificação da espécie (MNRJ 19149 ô 39.52 mm).. .23

Figura 5. Relação filogenética entre populações do complexo T. fluviatilis baseada em Inferência Bayesiana obtida pela análise de sequências parciais do gene $16 \mathrm{~S}$ (rRNA). Valores do nó representam probabilidade a posteriori $(\leq 50 \%$ não apresentados); BA: Bahia; ES: Espírito Santo; MG: Minas Gerais; RJ: Rio de Janeiro; SC: Santa Catarina; SE: Sergipe; SP: São Paulo; RS: Rio Grande do Sul. .28

Figura 6. Relação filogenética entre populações do complexo T. fluviatilis baseada em Máxima Verossimilhança obtida pela análise de sequências parciais do gene $16 \mathrm{~S}$ (rRNA). Valores do nó representam o suporte de bootstrap $(\leq 50 \%$ não apresentados); BA: Bahia; ES: Espírito Santo; MG: Minas Gerais; RJ: Rio de Janeiro; SC: Santa Catarina; SE: Sergipe; SP: São Paulo; RS: Rio Grande do Sul.

Figura 7. Relação filogenética entre populações do complexo T. fluviatilis baseada em Inferência Bayesiana obtida pela análise de sequências parciais do gene COI 
(rRNA). Valores do nó representam probabilidade a posteriori $(\leq 50 \%$ não apresentados); BA: Bahia; ES: Espírito Santo; MG: Minas Gerais; RJ: Rio de Janeiro; SC: Santa Catarina; SE: Sergipe; SP: São Paulo; RS: Rio Grande do Sul. 30

Figura 8. Relação filogenética entre populações do complexo T. fluviatilis baseada em Máxima Verossimilhança obtida pela análise de sequências parciais do gene COI (rRNA). Valores do nó representam o suporte de bootstrap $(\leq 50 \%$ não apresentados); BA: Bahia; ES: Espírito Santo; MG: Minas Gerais; RJ: Rio de Janeiro; SC: Santa Catarina; SE: Sergipe; SP: São Paulo; RS: Rio Grande do Sul. 31

Figura 9. Mapa com a distribuição do complexo T. fluviatilis analisados neste trabalho. 1- espécimes utilizados nas análises morfológicas e moleculares, 2- espécimes utilizados na análise morfológica, 3- exemplares de Trichodactylus fluviatilis sensu stricto utilizados nas análises morfológicas e moleculares, 4- exemplares de Trichodactylus fluviatilis sensu stricto utilizados nas análises morfológicas 32

Figura 10. Vista dorsal de exemplares de A: T. fluviatilis sensu stricto, RJ: Rio de Janeiro, MNRJ 19149 (ふึ, LC 39.52 mm); B: T. fluviatilis, SP: Porto Ferreira, CCDB $4173(\hat{\jmath}$, LC $26.94 \mathrm{~mm})$ 45

Figura 11. Vista dorsal de exemplares de A: Trichodactylus sp. 1, SP: Cananéia, CCDB 1772, (ð̂, LC 27.04 mm), B: Trichodactylus sp. 2, BA: Prado, CCDB 4186 (ð̂, LC $24.83 \mathrm{~mm})$ 46

Figura 12. Vista dorsal de exemplares de A: Trichodactylus cf. crassus, BA: Elísio Medrado, CCDB 3751 (ふ઼, LC 25.76 mm), B: Trichodactylus cf. crassus, SE: Estância, CCDB 4528 (ふ̋, LC $24.41 \mathrm{~mm})$ 47 
Figura 13. Vista dorsal de exemplares de A: Trichodactylus sp., BA: Ilhéus, CCDB 4529 (đ), LC 30.32 mm), B: Trichodactylus sp. 4, RS: São José dos Ausentes, INPA 1953 ( ठ઼, LC $29.94 \mathrm{~mm})$ 48

Figura 14. Vista mésio-ventral do gonópodo 1 direito de espécimes do complexo Trichodactylus fluviatilis. A: T. fluviatilis sensu stricto (MNRJ 19149, Ô, LC 39.52 mm); B: Trichodactylus aff. fluviatilis (CCDB 4668, 今̂, LC $32.67 \mathrm{~mm}$ ); C: Trichodactylus sp. 1 (CCDB 3697, Ô, LC 26.97 mm); D: Trichodactylus sp. 2 (CCDB 4186, §ิ, LC 25.06 mm); E: Trichodactylus sp. 3 (CCDB 4511, §̂, LC $29.32 \mathrm{~mm}) ; \mathrm{F}$ : Trichodactylus sp. 4 (CCDB 2679, $\hat{\jmath}$, LC $16.56 \mathrm{~mm}) ; \mathrm{G}$ : Trichodactylus sp. 4 (INPA 1963, Ô, LC 31.59 mm); H: Trichodactylus sp. 4 (INPA 1951, §̂, LC $18.16 \mathrm{~mm}$ ) 49

Figura 15. Imagem do gonópodo 1 direito (vista mésio-ventral) de espécimes do complexo T. fluviatilis feitas com Microscopia Eletrônica de Varredura. A, D: T. fluviatilis sensu stricto (CCDB 1574, LC $21.83 \mathrm{~mm}$ ); B, E: T. fluviatilis sensu stricto (CCDB 2075, LC 26.94 mm); C, F: Trichodactylus sp. 1 (CCDB 1772, LC 27.26 mm). D, E e F: vista apenas da porção distal do gonópodo 1 50

Figura 16. Imagem do gonópodo 1 direito (vista mésio-ventral) de espécimes do complexo T. fluviatilis feitas com Microscopia Eletrônica de Varredura. A, D: Trichodactylus sp. 2 (CCDB 4186, LC 25.06 mm); B, E: Trichodactylus cf. crassus (CCDB 3751, LC 25.89 mm); C, F: Trichodactylus sp. (CCDB 4529, LC 30.38 mm). D, E e F: vista apenas da porção distal. .51

Figura 17. Imagem do gonópodo 1 direito (vista mésio-ventral) de espécimes do complexo T. fluviatilis feitas com Microscopia Eletrônica de Varredura. C: Trichodactylus sp. 4 (INPA 1963, LC 31.596 mm); B, D: Trichodactylus sp. 4 
(INPA 1951, LC $18.16 \mathrm{~mm}$ ). C e D: vista apenas da porção distal do gonópodo. .52

Figura 18. Abdome e telso de machos de espécimes do complexo Trichodactylus fluviatilis. A: T. fluviatilis sensu stricto (CCDB 1574, LC $21.83 \mathrm{~mm}$ ); B: Trichodactylus aff. fluviatilis (CCDB 4668, LC $32.67 \mathrm{~mm}$ ); C: Trichodactylus sp. 1 (CCDB 3697, LC 26.97 mm); D: Trichodactylus sp. 2 (CCDB 4186, LC 25.06 mm); E: Trichodactylus sp. 3 (CCDB 4511, LC 29.32 mm); F: Trichodactylus cf. crassus (CCDB 3751, 2LC 5.89 mm); G: Trichodactylus sp. (CCDB 4529, LC $30.38 \mathrm{~mm}) ; \mathrm{H}:$ Trichodactylus cf. crassus (CCDB 4528, LC $24.13 \mathrm{~mm}$ ); I:

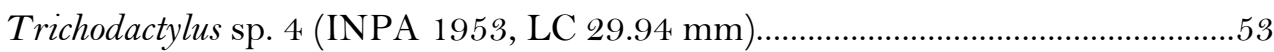




\section{LISTA DE TABELAS}

Tabela I. Primers utilizados na amplificação dos genes de interesse por meio da técnica de PCR (Polymerase Chain Reaction)..... .12

Tabela II. Espécimes de caranguejos utilizados nas análises genéticas. CCDB: Coleção de Crustáceos do Departamento de Biologia da Faculdade de Filosofia, Ciências e Letras de Ribeirão Preto, Universidade de São Paulo, Brasil; UFRGS: Universidade Federal do Rio Grande do Sul; INPA: Instituto Nacional de Pesquisas da Amazônia; MZUSP: Museu de Zoologia, Universidade de São Paulo. .14

Tabela III. Lista de caracteres utilizados na análise morfológica de exemplares do complexo Trichodactylus fluviatilis provenientes de diferentes localidades no Brasil. .20

Tabela IV. Matriz de divergência genética entre os clados encontrada para o gene 16S (rRNA) nos exemplares do complexo T. fluviatilis, calculado no MEGA com distância p. Média ( \pm erro padrão).

Tabela V. Matriz de divergência genética entre os clados encontrada para o gene COI (rRNA) nos exemplares do complexo T. fluviatilis, calculado no MEGA com distância p. Média ( \pm erro padrão). 26 


\section{LISTA DE ABREVIAÇÕES E SÍMBOLOS}

CCDB - Coleção de Crustáceos do Departamento de Biologia, Faculdade de Filosofia, Ciências e Letras de Ribeirão Preto, Universidade de São Paulo, Ribeirão Preto, SP

LBSC - Laboratório de Bioecologia e Sistemática de Crustáceos, Ribeirão Preto, SP

UNESP - Universidade Estadual Paulista Júlio de Mesquita Filho, Campus Jaboticabal e Bauru, SP

FCAV - Faculdade de Ciências Agrárias e Veterinárias de Jaboticabal, UNESP.

UESC - Universidade Estadual de Santa Cruz, Ilhéus, BA

MNRJ - Museu Nacional do Rio de Janeiro, Universidade Federal do Rio de Janeiro, Rio de Janeiro, RJ

UFPR - Universidade Federal do Paraná, Curitiba, PR

UFRGS - Universidade Federal do Rio Grande do Sul, Porto Alegre, RS

MZUSP - Museu de Zoologia, Universidade de São Paulo, São Paulo, SP

IB-USP - Instituto de Biociências, Universidade de São Paulo, São Paulo, SP

UFRB - Universidade Federal do Recôncavo Baiano, Cruz das Almas, BA

INPA - Instituto Nacional de Pesquisas das Amazônia, Manaus, AM

MHNCI - Museu de História Natural Capão da Imbuia, Curitiba, PR

MNHN - Muséum National d'Histoire Naturelle, Paris, França

UFERSA - Universidade Federal Rural do Semi-Árido, Mossoró, RN

UFPE - Universidade Federal de Pernambuco, Recife, PE

UFV - Universidade Federal de Viçosa, Viçosa, MG

UVV - Universidade de Vila Velha, ES

MMA - Ministério de Meio Ambiente

IBAMA - Instituto Brasileiro do Meio Ambiente e dos Recursos Naturais Renováveis MEV - Microscopia Eletrônica de Varredura 
DNTPS - Desoxirribonucleotídeos fosfatados

BioEdit - Biological sequence alignment editor written for Windows 95/98/NT/2000/XP/7

LC - Largura da Carapaça

GenBank - Genetic Sequence Database

ML - Máximo Likelihood

BI - Bayesian Inference

JModeltest - HPC selection of models of nucleotide substitution

MEGA - Molecular Evolutionary Genetics Analysis

CIPRES - Cyberinfrastructure for Phylogenetic Research

MAFT - Multiple Alignment Program for Amino Acid or Nucleotide Sequences

BLAST - Basic Local Alignment Search Tool

NCBI - National Center for Biotechnology Information

RaxML - Randomized Axelerated Maximum Likelihood

mm - Milímetros

M - Molar

$\mu \mathrm{l}$ - microlitros

$\boldsymbol{\mu} \mathbf{M}$ - Micromolar

ठิ - Macho

q - Fêmea 


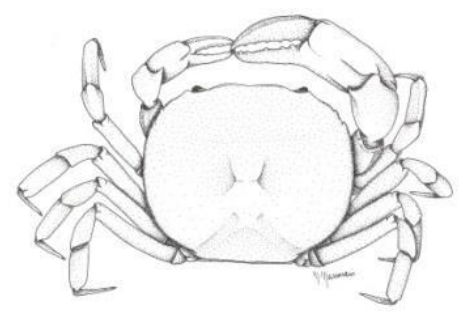

1. INTRODUÇ ÃO 
Charles Darwin, durante suas observações, já notava a variação morfológica que muitos organismos apresentavam, sendo estes dos mesmos locais ou de áreas geográficas distintas. De acordo com Darwin alguns naturalistas da época afirmavam que os animais nunca apresentariam formas ou variedades; do mesmo modo que quando encontravam uma forma idêntica em duas regiões afastadas, afirmavam que duas espécies distintas estariam ocultas sob o mesmo invólucro. Em seu livro ( $A$ Origem das Espécies), Darwin traz uma nota feita por M. A. Candolle: "aqueles que admitem que a maior parte das nossas espécies são nitidamente delimitadas e que as espécies duvidosas são a pequena minoria, enganam-se com certeza. À medida em que melhor se conhece um gênero, descobrem-se formas intermediárias e as dúvidas aumentam quanto aos limites específicos" (Darwin, 2009).

Em quase todas as espécies os indivíduos apresentam variações comportamentais, fisiológicas, em nível celular, morfológicas, dentre outras (Ridley, 2006; Schwander \& Leimar, 2011). Tais variações fenotípicas podem ser resultados de diferenças genéticas entre os indivíduos e polifenismo, ou a combinação de ambos (Schwander \& Leimar, 2011).

As espécies foram originalmente definidas de modo tipológico por suas diferenças morfológicas, sendo este conceito aplicado até o momento por alguns taxonomistas. Porém, este conceito deve ser visto com cuidado para determinados grupos de organismos que são aparentemente muitos diferentes, mas são coespecíficos. Por outro lado, algumas formas - as espécies crípticas - são indistinguíveis morfologicamente, mas divergem em outras características biológicas e são isoladas reprodutivamente, além de apresentarem distribuição mais restrita (Futuyma, 1992).

A dificuldade no reconhecimento de espécies crípticas, devido, às semelhanças morfológicas, pode ocasionar muitos erros de identificação e, consequentemente, uma 
perda de informações sobre a biodiversidade. A falta de caracteres que definam com clareza os limites de cada forma pode levar a valores subestimados da diversidade de determinados grupos de organismos (Lebéfure et al., 2006; Pfenninger \& Schwenk, 2007).

Muitos grupos de organismos como, por exemplo, os crustáceos decápodos, são identificados e descritos utilizando apenas caracteres morfológicos por serem estes de fácil acesso e menos custosos quando comparados às outras técnicas (Carvalho et al., 2013). Atualmente as técnicas moleculares vêm contribuindo na identificação de espécies crípticas juntamente com a taxonomia morfológica. Muitos estudos realizados nos últimos anos com a utilização de técnicas moleculares descobriram linhagens muito divergentes genética e morfologicamente similares (Pfenninger \& Schwenk, 2007). As ferramentas moleculares fornecem um maior número de caracteres para análise e estes, não apresentam plasticidade em função do ambiente. Dessa forma, ela tem se mostrado bastante informativa na resolução de problemas taxonômicos em crustáceos decápodos, na construção de hipóteses de relações filogenéticas e na delimitação de espécies crípticas (Futuyma, 1992; Schubart et al., 2000; Tang et al., 2003; Lefébure et al., 2006; Ridley, 2006; Mantelatto et al., 2009; Jesse et al., 2010; Pileggi \& Mantelatto, 2010; Negri et al., 2012, Carvalho et al., 2013).

Dentre os Crustacea Decapoda, a infraordem Brachyura, que engloba os caranguejos verdadeiros, é a mais diversa, sendo composta principalmente por representantes marinhos ( $\mathrm{Ng}$ et al., 2008). Das aproximadamente 6.700 espécies descritas nesse grupo, 1.300 são representadas pelos caranguejos de água doce, caracterizados por realizar todo o seu ciclo de vida em ambientes dulcícolas sem qualquer dependência de águas marinhas e estuarinas (Magalhães, 2003; $\mathrm{Ng}$ et al., 2008; Yeo et al., 2008; Cumberlidge \& Ng, 2009). 
Ao longo de sua história evolutiva, os caranguejos de água doce desenvolveram adaptações muito importantes para seu sucesso no ambiente dulcícola. Essas estratégias compreendem: capacidade de dispersão limitada, produção de ovos de tamanho grande e número reduzido e, consequentemente, uma baixa taxa de fecundidade, além de apresentar cuidado parental e desenvolvimento epimórfico (direto) (Rodríguez, 1981; Anger, 1995; Ng \& Yeo, 2007; Yeo et al., 2008). Esse tipo de desenvolvimento e a capacidade de dispersão muito limitada aliados à fragmentação dos hábitats, heterogeneidade ambiental e topografia de cada local, resultam num isolamento frequente de várias espécies ( $\mathrm{Ng} \&$ Yeo, 2007; Fang et al., 2013). Esse isolamento, muitas vezes, faz com que essas populações não tenham fluxo gênico, o que acarretaria numa fixação de alelos e uma diferenciação genética entre as populações, ocasionando a especiação alopátrica por isolamento geográfico e a especiação simpátrica por meio da especialização de nichos, além de altos níveis de endemismo (Sternberg \& Cumberlidge, 2001; Ng \& Yeo, 2007; Yeo et al., 2008; Cumberlidge et al., 2009, Carvalho et al., 2013).

Os caranguejos de água doce são encontrados em uma ampla diversidade de hábitats, como rios, córregos, lagoas, áreas alagáveis, cachoeiras e cavernas (Magalhães, 2003; Yeo et al., 2008a). De forma geral, apresentam hábitos crípticos e noturnos, permanecendo escondidos em tocas, fendas e buracos de rochas e de troncos submersos, buracos marginais, na serrapilheira submersa ou entre as raízes e folhas da vegetação aquática (Mello, 1967; Magalhães, 1999).

Atualmente estão alocados em cinco famílias: Potamonautidae Bott, 1970, Potamidae Ortmann, 1896, Gecarcinucidae Rathbun, 1904, Pseudothelphusidae Ortmann, 1893 e Trichodactylidae H. Milne Edwards, 1853 (Cumberlidge \& Ng, 2009; Cumberlidge et al., 2009; Klaus et al., 2011). Destas, apenas as famílias Pseudothelphusidae e Trichodactylidae ocorrem no Brasil, sendo que esta última 
engloba mais de 60\% das espécies descritas com ocorrência no Brasil (Rodríguez, 1992; Magalhães \& Turkay, 1996 a,b,c; Magalhães, 2003).

A família Trichodactylidae tem uma origem filogenética distinta de todas as demais famílias de caranguejo de água doce (Cumberlidge \& Ng, 2009; Sternberg et al.,1999). Essa família apresenta caracteres morfológicos que a distingue das demais: não possuem espinhos nos dáctilos e própodos, apresentam o mero do terceiro maxilípede estreito e uma forma corporal completamente diferente de todas as outras famílias de caranguejos de água doce (Magalhães, 2003; Sternberg \& Cumberlidge, 2003). Atualmente ela é composta por 49 espécies que estão alocadas em 15 gêneros distribuídos em duas subfamílias: Trichodactylinae H. Milne Edwards, 1853 e Dilocarcininae Pretzmann, 1978 (Magalhães \& Turkay, 1996a; Ng et al., 2008). A subfamília Trichodactylinae está composta por 15 espécies alocadas nos gêneros Trichodactylus Latreille, 1828, Rodriguezia Bott, 1969 e Avotrichodactylus Pretzmann, 1968 ( $\mathrm{Ng}$ et al., 2008).

Trichodactylus atualmente composto por onze espécies ( $\mathrm{Ng}$ et al., 2008), foi descrito por Latreille (1828) para acomodar uma única espécie, Trichodactylus fluviatilis, considerada a espécie-tipo.

Constata-se que a delimitação de algumas espécies deste gênero, como $T$. fluviatilis, T. petropolitanus (Göldi, 1886) e T. dentatus H. Milne Edwards, 1853, é dificultada por causa da morfologia externa bem conservativa e a expressiva variabilidade de alguns caracteres utilizados na identificação dessas espécies (Magalhães, 1991). Tais variações levantam dúvidas se os padrões encontrados na morfologia representam espécies distintas ou apenas variações intraespecíficas (Magalhães, 1991). 
A espécie $T$. crassus A. Milne-Edwards 1869, também é bem semelhante morfologicamente com T. fluviatilis. Bott (1969) considerou T. crassus como subespécie de $T$. fluviatils e sugeriu que crassus poderia ser tratada como sinônimo.

Trichodactylus fluviatilis (Figura 1), considerada um caranguejo exclusivamente de água doce, é endêmica do Brasil e ocorre em áreas insulares e continentais, principalmente costeiras, sendo registrada para Pernambuco, Alagoas, Sergipe, Bahia, Minas Gerais, Espírito Santo, Rio de Janeiro, São Paulo, Paraná, Santa Catarina e Rio Grande do Sul (Magalhães, 2003).

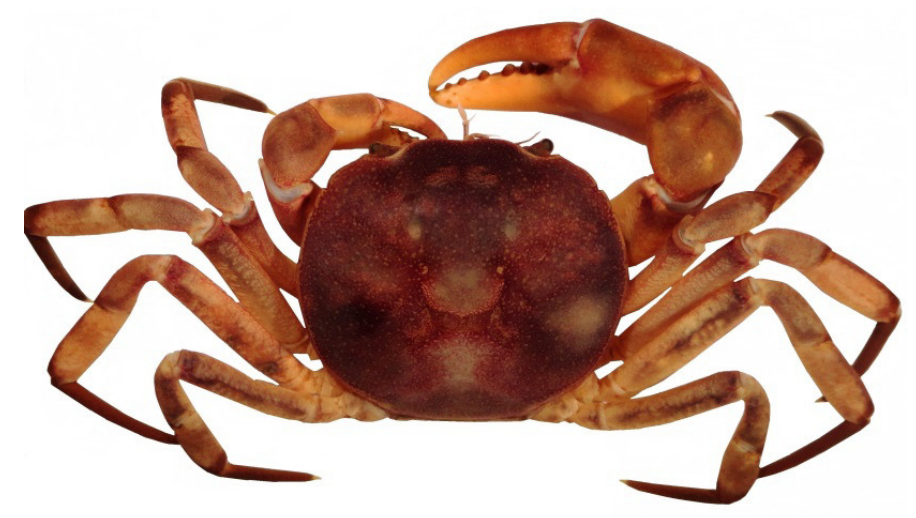

Figura 1: Exemplar de Trichodactylus fluviatilis Latreille, 1828 (ðึCCDB 2072, Ilhabela, SP).

Em São Paulo, essa espécie foi coletada em áreas afastadas da costa e em uma área insular. Rocha \& Bueno (2004), registraram a ocorrência de T. fluviatilis em rios da Serra de Paranapiacaba em altitudes de até $500 \mathrm{~m}$ e cerca de $65 \mathrm{~km}$ afastado da costa. Mello (1967) encontrou esse caranguejo em outras áreas afastadas da costa, como Piracicaba, Cerqueira César e Corumbatai. Mossolin \& Mantelatto (2008) encontraram a espécie na Ilha de São Sebastião, Ilhabela. Gomides et al. (2009) registraram $T$. fluviatilis a uma altitude de $770 \mathrm{~m}$ 
Essa espécie apresenta uma variação considerável em muitos caracteres morfológicos, como já constatado em alguns trabalhos (Göldi, 1885, 1886; Rathbun, 1906; Mello, 1967; Magalhães, 1991; Almeida et al., 2008). Caracteres morfológicos presentes na carapaça, abdome e gonópodo apresentam uma expressiva variação ao longo da sua distribuição.

A plasticidade morfológica dessa espécie é tão pronunciada que pode ser verificada em grupos de uma mesma bacia hidrográfica quanto entre indivíduos de um mesmo lote (Magalhães, 1991). Diante dessa situação, alguns trabalhos acham aconselhável considerar a espécie como um complexo de formas e não como subespécies ou variedades (Mello, 1967; Magalhães, 1991).

Como a utilização de caracteres morfológicos não tem proporcionado informações conclusivas sobre a situação taxonômica de $T$. fluviatilis, pretende-se averiguar neste trabalho, se a utilização da ferramenta molecular poderá contribuir para melhor esclarecer os limites específicos desse táxon, bem como no entendimento da divergência genética que pode estar ocorrendo nas populações dessas espécie (Mayr, 1977). 


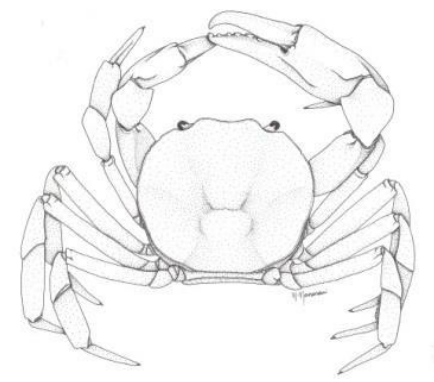

2. OBJETIVOS 
Diante deste cenário de dúvidas relatado anteriormente o presente estudo teve como objetivos:

\subsection{Objetivo Geral}

Testar a hipótese sobre a validade da espécie, avaliando as relações de parentesco entre as populações e se estas constituem um clado monofilético.

\subsection{Objetivos Específicos}

1- Comparar e caracterizar as populações de T. fluviatilis oriundas de diferentes bacias hidrográficas por meio de uma revisão taxonômica, determinando a variabilidade dos caracteres examinados;

2- Mapear o grau de variabilidade e estruturação genética das populações de $T$. fluviatilis oriundas de diferentes bacias hidrográficas. 


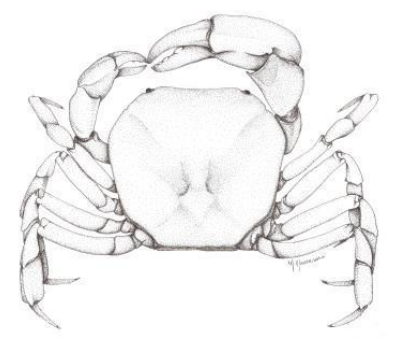

3. MATERIAL \& MÉTODOS 


\subsection{Obtenção dos espécimes}

Espécimes de diferentes populações de $T$. fluviatilis foram obtidos por meio de coletas realizadas em rios, córregos, riachos e cachoeiras (Figura 2). Essas coletas foram realizadas de forma manual sob pedras e buracos marginais e utilizando-se puçás e peneiras na serrapilheira submersa ou entre as raízes e folhas da vegetação aquática.

Os animais foram coletados com permissão dos órgãos responsáveis (ICMBio 31906-1 e MMA/IBAMA/SISBIO 11777-1). Após a coleta, os exemplares foram conservados em álcool etílico 80\%, identificados, tombados e depositados na coleção na Coleção de Crustáceos do Departamento de Biologia (CCDB) da Faculdade de Filosofia, Ciências e Letras de Ribeirão Preto (FFCLRP), Universidade de São Paulo (USP). O material obtido por meio de doação foi devidamente etiquetado, conservado em álcool etílico $80 \%$ e incorporado à CCDB.

Além da análise do material da $\mathrm{CCDB}$, foram realizadas visitas às seguintes instituições: Instituto Nacional de Pesquisas da Amazônia (INPA), Manaus/AM; Museu Nacional, Universidade Federal do Rio de Janeiro (MNRJ), Rio de Janeiro/RJ; Museu de Zoologia, Universidade de São Paulo (MZUSP), São Paulo/SP; Universidade Estadual de Santa Cruz (UESC), Ilhéus/BA. Empréstimos de material provenientes das coleções citadas e de outras também foram solicitados: Coleção Zoológica do Departamento de Oceanografia da Universidade Federal de Pernambuco (UFPE), Recife/PE; Coleção Zoológica do Departamento de Zoologia da Universidade Federal do Rio Grande do Sul (UFRGS), Porto Alegre/RS e Museu de História Natural Capão da Imbuia (MHNCI), Curitiba/PR. 


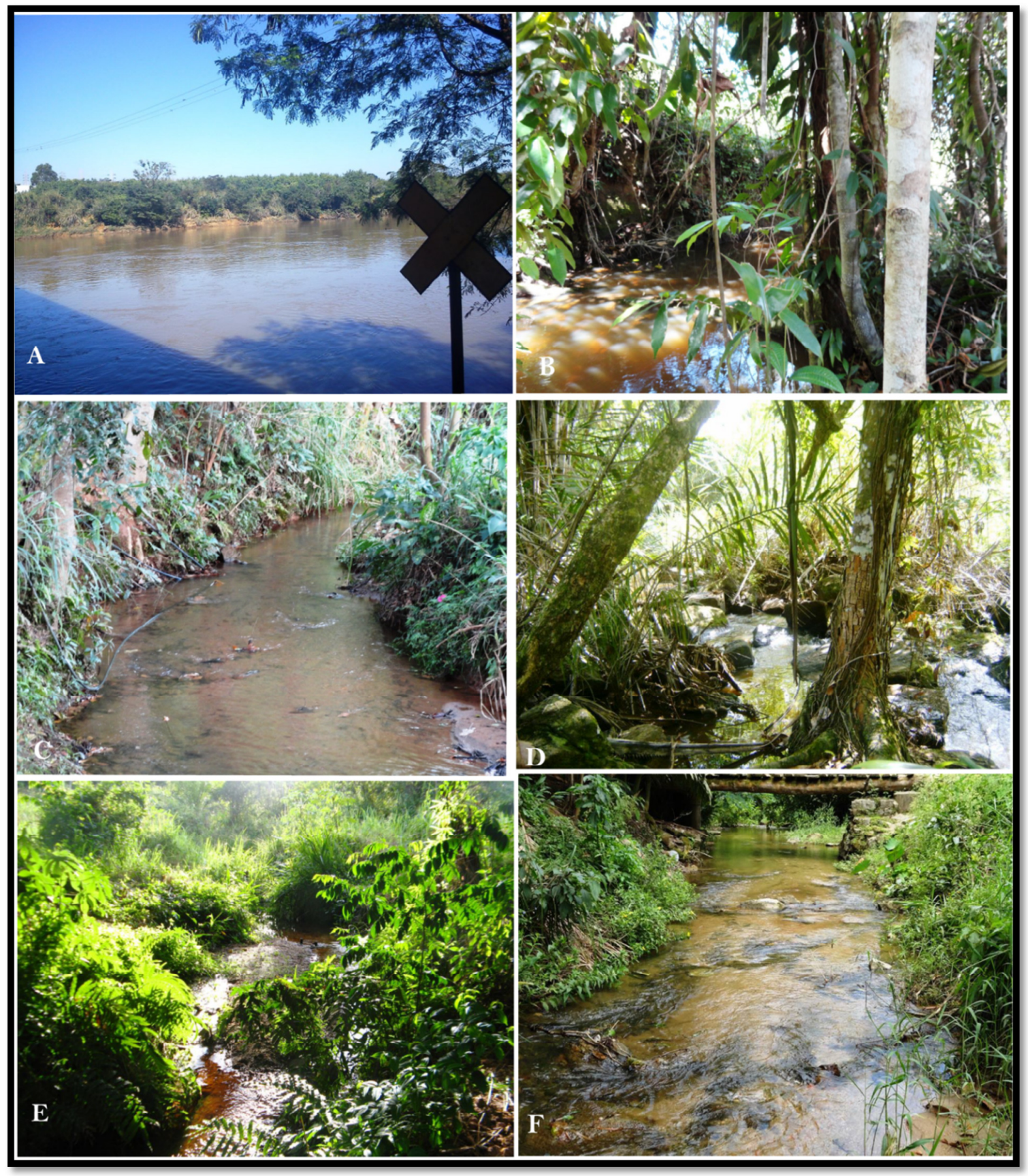

Figura 2: Ambientes de coleta dos exemplares de Trichodactylus fluviatilis. A: Porto

Ferreira (SP); B: Prado (BA); C: Iconha (ES); D: Elísio Medrado (BA); E: Estância (SE);

F: Camboriú (SC). 


\subsection{Obtenção dos dados moleculares}

\subsubsection{Escolha dos marcadores}

Dentre os genes mitocondriais que vêm sendo utilizados em estudos populacionais e sobre relações filogenéticas em crustáceos decápodos, destacam-se o 16S rRNA e o citocromo c oxidase subunidade I (COI) (Schubart, 2000; Harrison, 2004; Francisco \& Galetti Júnior, 2005; Daniels et al., 2006; Liu et al., 2007; Mantelatto et al., 2007; Schubart et al., 2008; Mantelatto et al., 2009a e b; Pileggi \& Mantelatto, 2010; Vergamini et al., 2011; Rossi \& Mantelatto, 2013). O gene 16S é um gene estrutural, não codificante, cuja combinação de regiões conservadas e variáveis é provavelmente um dos motivos de sua grande popularidade em estudos sobre reconstruções filogenéticas animais (Schubart, 2000). Este gene, por ser mais conservado e ser um marcador capaz de distinguir variações no âmbito específico, foi utilizado com a finalidade de testar a validade da espécie e também contextualizar as populações. O gene COI por ser menos conservado foi escolhido para mapear a estrutura e variabilidade genética entre as populações reconhecidas morfologicamente como T. fluviatilis.

\subsubsection{Obtenção dos dados}

As sequências foram obtidas por meio de protocolos, seguindo a metodologia de Mantelatto et al. (2006, 2007 e 2009a, b) com alguns ajustes necessários visando adequação ao material.

As sequências do gene $16 \mathrm{~S}$ foram obtidas de ao menos um indivíduo de cada população de T. fluviatilis. Contudo, para o gene COI, foram obtidas sequências parciais de no mínimo 2 indivíduos de cada população, dependendo da disponibilidade de material. Todos os testemunhos genéticos, dos quais foram obtidas amostras de tecido para análise, foram depositados na CCDB/FFCLRP/USP ou na coleção de origem. 


\section{Extração do DNA}

Para a extração foram utilizados preferencialmente indivíduos de maior tamanho, adultos e machos. O DNA foi extraído do tecido muscular dos quelípodos. Esse tecido foi incubado por $24 \mathrm{~h}$ em $600 \mu \mathrm{l}$ de tampão de lise à $55^{\circ} \mathrm{C}$, juntamente com proteinase $(\mathrm{PK})$. As amostras foram colocadas em gelo por $10 \mathrm{~min}$ para inativar a atividade da PK. As proteínas foram separadas pela adição de $200 \mu \mathrm{l}$ de acetato de amônio (7,5 M) e a amostra centrifugada a 14.00orpm por 10min. O DNA foi precipitado pela adição de $600 \mu \mathrm{l}$ isopropanol resfriado $\left(-20^{\circ} \mathrm{C}\right)$ seguido de centrifugação a 14.000 rpm por 10 min. A amostra resultante ficou no freezer $\left(20^{\circ} \mathrm{C}\right)$ por 48h. Posteriormente, essa amostra foi centrifugada a 14.000rpm por 10min e após, teve o sobrenadante descartado. O pellet resultante foi lavado com etanol $70 \%$, liofilizado e ressuspendido em $30 \mu \mathrm{l}$ de tampão TE 1x. A concentração e a qualidade do DNA extraído foram quantificadas em espectrofotômetro (NanoDrop ${ }^{\circledR}$ 2000/2000c).

\section{Amplificação do DNA}

A região de interesse (fragmentos dos genes mitocondriais $16 \mathrm{~S}$ e COI) foi amplificada por meio da técnica de PCR (Polymerase Chain Reaction) utilizando primers específicos (Tabela I). Os produtos de PCR foram obtidos em reação de $25 \mu \mathrm{l}$ contendo água destilada e deionizada, Betaína 5M, PCR Buffer 10x, $\mathrm{MgCl}_{2}$ 25mM, DNTPs, primers (16S 10 $\mu \mathrm{M}$, COI $20 \mu \mathrm{M})$, Thermus aquaticus (Taq polimerase) (5 U/ $\mu \mathrm{l})$ e uma determinada concentração de DNA previamente calculada.

A amplificação do DNA foi realizada em um termociclador Applied Biosystems Veriti 96 Well Thermal Cycler $^{\circledR}$ com os seguintes ciclos termais: $16 \mathrm{~S}$ - desnaturação inicial por $5 \mathrm{~min}$ a $95^{\circ} \mathrm{C}$; pareamento por 40 ciclos $\left(45 \mathrm{~s}\right.$ a $95^{\circ} \mathrm{C} ; 45 \mathrm{~s}$ a $44-48^{\circ} \mathrm{C}$ e $1 \mathrm{~min}$ a $72^{\circ} \mathrm{C}$ ); extensão final por 3 min a $72^{\circ} \mathrm{C}$; COI - desnaturação inicial por 2 min a $94{ }^{\circ} \mathrm{C}$; pareamento por $35 \operatorname{ciclos}\left(45 \mathrm{~s}\right.$ a $94^{\circ} \mathrm{C}$; $0.45 \mathrm{~s}$ a $44-50^{\circ} \mathrm{C}$ e 1 min a $\left.72^{\circ} \mathrm{C}\right)$; extensão final 
por 5 min a $72^{\circ} \mathrm{C}$. Os resultados obtidos foram observados em eletroforese com gel de agarose $1,5 \%$ e fotografados com câmara digital C-7070 Olimpus ${ }^{\circledR}$ em um transluminator UV M20 UVP.

Tabela I: Primers utilizados na amplificação dos genes de interesse por meio da técnica de PCR (Polymerase Chain Reaction).

\begin{tabular}{lccc}
\hline Gene & Primer & Sequência & Referência \\
\hline $16 \mathrm{~S}$ & H9 & CCGGTCTGAACTCAGATCACGT & Schubart \& Huber, 2006 \\
& L9 & CGCCTGTTTATCAAAAACAT & \\
COI & LCO $1-1490$ & CGCCTGTTTATCAAAAACAT & Folmer et al., 1994 \\
& HCO $1-2198$ & TAAACTTCAGGGTGACCAAAAAATCA & \\
\hline
\end{tabular}

Purificação e amplificação dos produtos do PCR

A purificação foi realizada por meio do kit SureClean Plus ${ }^{\circledR}$ e o sequenciamento das amostras foram realizados em um sequenciador automático ABI 3730 XL DNA Analyzer $^{\circledR}$ (Applied Biosystems, Foster City, California, CA) no Departamento de Tecnologia da Faculdade de Ciências Agrárias e Veterinárias de Jaboticabal, Universidade Estadual Paulista “Júlio de Mesquita Filho" (FCAV-UNESP), por meio do kit de reação ABI Big Dye ${ }^{\circledR}$ Terminator Mix (Applied Biosystems).

\section{Edição de sequências}

Todas as sequências obtidas foram confirmadas pelo sequenciamento de ambas as fitas (senso e anti-senso). A edição e o consenso de ambas as fitas foram realizadas utilizando-se o software BioEdit 7.0.5 (Hall, 2005). As sequências consenso obtidas foram submetidas ao sistema BLAST para comparação com a assembleia do banco de 
dados NCBI (http://blast.ncbi.ncbi.nlm.nih.gov/blast.cgi) visando a confirmação de suas respectivas identidades. No entanto, não existe nenhuma sequência de $T$. fluviatilis no banco de dados, apenas algumas poucas da família Trichodactylidae. Portanto, ao comparar as sequências obtidas com o banco de dados, verificou-se a similaridade com algumas espécies de Trichodactylidae e outras pertencentes a diferentes famílias de caranguejos de água doce.

As sequências obtidas foram editadas no software BioEdit 7.0.5 (Hall, 2005) e posteriormente alinhadas no MAFFT versão 6 (Katoh \& Toh, 2008). Estas também foram traduzidas no intuito de verificar a existência de pseudogenes, os quais poderiam prejudicar as análises. Posteriormente todas as sequências foram submetidas ao banco de dados genéticos - Genbank (ver números de acessos na Tabela II).

Foram adotados como grupo externo alguns representantes da família Trichodactylidae tais como Trichodactylus faxoni Rathbun, 1905, T. borellianus Nobili, 1896, T. panoplus (von Martens, 1869), Sylviocarcinus pictus (H. Milne Edwards, 1853), Sylviocarcinus devillei $\mathrm{H}$. Milne Edwards, 1853 e Valdivia serrata White, 1847. 
Tabela II. Espécimes de caranguejos da família Trichodactylidae utilizados nas análises genéticas. CCDB: Coleção de Crustáceos do Departamento de Biologia da Faculdade de Filosofia, Ciências e Letras de Ribeirão Preto, Universidade de São Paulo, Ribeirão Preto, Brasil; INPA: Coleção de Crustáceos do Instituto Nacional de Pesquisas da Amazônia, Manaus, Brasil; MZUSP: Museu de Zoologia, Universidade de São Paulo, São Paulo, Brasil; UFRGS: Coleção de Crustáceos da Universidade Federal do Rio Grande do Sul, Porto Alegre, Brasil.

\begin{tabular}{|c|c|c|c|c|}
\hline \multirow[t]{2}{*}{ Táxon } & \multirow[t]{2}{*}{ Localidade } & \multirow{2}{*}{$\begin{array}{l}\text { Tombo em } \\
\text { Coleção }\end{array}$} & \multicolumn{2}{|c|}{ GenBank } \\
\hline & & & $16 \mathrm{~S}$ & COI \\
\hline $\begin{array}{l}\text { Trichodactylus fluviatilis } \\
\text { Latreille, } 1828\end{array}$ & $\begin{array}{l}\text { Cananéia, São } \\
\text { Paulo }\end{array}$ & $\begin{array}{l}\text { CCDB } 1772 \\
(\mathrm{x}-\text { dna } 25)\end{array}$ & KF688006 & - \\
\hline Trichodactylus fluviatilis & $\begin{array}{l}\text { Cananéia, São } \\
\text { Paulo }\end{array}$ & $\begin{array}{l}\text { CCDB } 1772 \\
(\mathrm{x}-\mathrm{dna} 35)\end{array}$ & KF688010 & KF688062 \\
\hline Trichodactylus fluviatilis & $\begin{array}{l}\text { Cananéia, São } \\
\text { Paulo }\end{array}$ & $\begin{array}{l}\text { CCDB } 1772 \\
(x-d n a ~ 41)\end{array}$ & KF688012 & KF688065 \\
\hline Trichodactylus fluviatilis & $\begin{array}{l}\text { São Pedro, São } \\
\text { Paulo }\end{array}$ & $\begin{array}{l}\text { CCDB 1574 } \\
(\mathrm{x}-\mathrm{dna} 31)\end{array}$ & KF688008 & KF688060 \\
\hline Trichodactylus fluviatilis & $\begin{array}{l}\text { São Pedro, São } \\
\text { Paulo }\end{array}$ & $\begin{array}{l}\text { CCDB } 1574 \\
(x-d n a ~ 75)\end{array}$ & KF688021 & KF688074 \\
\hline Trichodactylus fluviatilis & $\begin{array}{l}\text { Paulistânia, São } \\
\text { Paulo }\end{array}$ & $\begin{array}{l}\text { CCDB } 3791 \\
(x-d n a ~ 76)\end{array}$ & KF688022 & - \\
\hline Trichodactylus fluviatilis & $\begin{array}{l}\text { Paulistânia, São } \\
\text { Paulo }\end{array}$ & $\begin{array}{l}\text { CCDB } 3791 \\
(x-\text { dna } 41)\end{array}$ & KF 688041 & - \\
\hline Trichodactylus fluviatilis & $\begin{array}{l}\text { Porto Ferreira, } \\
\text { São Paulo }\end{array}$ & $\begin{array}{l}\text { CCDB } 4173 \\
(x-\text { dna } 115)\end{array}$ & KF688035 & - \\
\hline Trichodactylus fluviatilis & $\begin{array}{l}\text { Santa Rita do } \\
\text { Passa Quatro, } \\
\text { São Paulo }\end{array}$ & $\begin{array}{l}\text { CCDB } 2296 \\
\text { x-dna } 44)\end{array}$ & KF688014 & KF688067 \\
\hline Trichodactylus fluviatilis & $\begin{array}{l}\text { Ubatuba, São } \\
\text { Paulo }\end{array}$ & $\begin{array}{l}\text { CCDB } 3879 \\
\text { (x-dna 39) }\end{array}$ & KF688011 & KF688064 \\
\hline Trichodactylus fluviatilis & $\begin{array}{l}\text { Ubatuba, São } \\
\text { Paulo }\end{array}$ & $\begin{array}{l}\text { CCDB 3454 } \\
(x-\text { dna } 37)\end{array}$ & - & KF688063 \\
\hline Trichodactylus fluviatilis & $\begin{array}{l}\text { Ilha Comprida, } \\
\text { São Paulo }\end{array}$ & $\begin{array}{l}\text { CCDB } 1775 \\
\text { (x-dna 48) }\end{array}$ & KF688016 & - \\
\hline Trichodactylus fluviatilis & $\begin{array}{l}\text { Ilha Comprida, } \\
\text { São Paulo }\end{array}$ & $\begin{array}{l}\text { CCDB } 3792 \\
(x-d n a 95)\end{array}$ & KF688030 & - \\
\hline Trichodactylus fluviatilis & $\begin{array}{l}\text { Ilha Comprida, } \\
\text { São Paulo }\end{array}$ & $\begin{array}{l}\text { CCDB } 3187 \\
(x-d n a 97)\end{array}$ & KF688031 & KF688059 \\
\hline
\end{tabular}


Tabela II. Continuação

\begin{tabular}{|c|c|c|c|c|}
\hline \multirow[t]{2}{*}{ Táxon } & \multirow[t]{2}{*}{ Localidade } & \multirow[t]{2}{*}{$\begin{array}{l}\text { Tombo em } \\
\text { Coleção }\end{array}$} & \multicolumn{2}{|c|}{ GenBank } \\
\hline & & & $16 S$ & COI \\
\hline Trichodactylus fluviatilis & $\begin{array}{l}\text { Ilhabela, São } \\
\text { Paulo }\end{array}$ & $\begin{array}{l}\mathrm{CCDB} 2072 \\
(\mathrm{x}-\mathrm{dna} 43)\end{array}$ & KF688013 & KF688066 \\
\hline Trichodactylus fluviatilis & $\begin{array}{l}\text { Ilhabela, São } \\
\text { Paulo }\end{array}$ & $\begin{array}{l}\text { CCDB 2074 } \\
(x-d n a 14)\end{array}$ & - & KF688054 \\
\hline Trichodactylus aff. fluviatils & $\begin{array}{l}\text { Bocaina de } \\
\text { Minas, Minas } \\
\text { Gerais }\end{array}$ & $\begin{array}{l}\text { CCDB } 4668 \\
\text { (x-dna 206) }\end{array}$ & KF688049 & KF688089 \\
\hline Trichodactylus aff. fluviatlis & $\begin{array}{l}\text { Resende, Rio de } \\
\text { Janeiro }\end{array}$ & $\begin{array}{l}\text { CCDB } 4643 \\
\text { (x-dna 179) }\end{array}$ & KF688048 & KF688088 \\
\hline Trichodactylus aff. fluviatilis & $\begin{array}{l}\text { Alto do } \\
\text { Jequitibá, Minas } \\
\text { Gerais }\end{array}$ & $\begin{array}{l}\text { CCDB } 2729 \\
(x-d n a 53)\end{array}$ & - & KF688069 \\
\hline Trichodactylus aff. fluviatlis & $\begin{array}{l}\text { Alto do } \\
\text { Jequitibá, Minas } \\
\text { Gerais }\end{array}$ & $\begin{array}{l}\text { CCDB } 2729 \\
(x-d n a ~ 86)\end{array}$ & - & KF688079 \\
\hline Trichodactylus aff. fluviatlis & $\begin{array}{l}\text { Dores do Rio } \\
\text { Preto, Espírito } \\
\text { Santo }\end{array}$ & $\begin{array}{l}\text { CCDB } 2728 \\
\text { (x-dna 22) }\end{array}$ & - & KF688057 \\
\hline Trichodactylus aff. fluviatlis & $\begin{array}{l}\text { Dores do Rio } \\
\text { Preto, Espírito } \\
\text { Santo }\end{array}$ & $\begin{array}{l}\mathrm{CCDB} 2728 \\
(\mathrm{x}-\mathrm{dna} 52)\end{array}$ & - & KF 688068 \\
\hline Trichodactylus sp. 3 & $\begin{array}{l}\text { Serra, Espírito } \\
\text { Santo }\end{array}$ & $\begin{array}{l}\text { CCDB } 4511 \\
(x-d n a 154)\end{array}$ & KF688043 & - \\
\hline Trichodactylus sp. 3 & $\begin{array}{l}\text { Serra, Espírito } \\
\text { Santo }\end{array}$ & $\begin{array}{l}\text { CCDB } 4511 \\
(x-d n a 155)\end{array}$ & KF688044 & - \\
\hline Trichodactylus sp. 3 & $\begin{array}{l}\text { Iconha, Espírito } \\
\text { Santo }\end{array}$ & $\begin{array}{l}\text { CCDB } 3987 \\
(x-d n a ~ 87)\end{array}$ & Kf688027 & - \\
\hline Trichodactylus sp. 3 & $\begin{array}{l}\text { Iconha, Espírito } \\
\text { Santo }\end{array}$ & $\begin{array}{l}\text { CCDB } 3987 \\
\text { (x-dna 138) }\end{array}$ & KF688039 & - \\
\hline Trichodactylus sp. 2 & Prado, Bahia & $\begin{array}{l}\text { CCDB } 4186 \\
(x-d n a 112)\end{array}$ & KF688032 & KF688083 \\
\hline Trichodactylus sp. 2 & Prado, Bahia & $\begin{array}{l}\mathrm{CCDB} 4174 \\
(\mathrm{x}-\mathrm{dna} 113)\end{array}$ & KF688033 & KF688084 \\
\hline Trichodactylus sp. 2 & Prado, Bahia & $\begin{array}{l}\mathrm{CCDB} 4200 \\
(\mathrm{x}-\mathrm{dna} 114)\end{array}$ & KF688034 & KF688085 \\
\hline
\end{tabular}


Tabela II. Continuação

\begin{tabular}{|c|c|c|c|c|}
\hline \multirow[t]{2}{*}{ Táxon } & \multirow[t]{2}{*}{ Localidade } & \multirow{2}{*}{$\begin{array}{l}\text { Tombo em } \\
\text { Coleção }\end{array}$} & \multicolumn{2}{|c|}{ GenBank } \\
\hline & & & $16 S$ & COI \\
\hline Trichodactylus sp. 2 & $\begin{array}{l}\text { Porto Seguro, } \\
\text { Bahia }\end{array}$ & $\begin{array}{l}\text { CCDB 3294 } \\
(\mathrm{x}-\mathrm{dna} 28)\end{array}$ & KF 688007 & - \\
\hline Trichodactylus sp. 2 & $\begin{array}{l}\text { Porto Seguro, } \\
\text { Bahia }\end{array}$ & $\begin{array}{l}\text { CCDB 2294 } \\
(x-d n a 132)\end{array}$ & KF688038 & - \\
\hline Trichodactylus sp. 2 & $\begin{array}{l}\text { Porto Seguro, } \\
\text { Bahia }\end{array}$ & $\begin{array}{l}\mathrm{CCDB} 3294 \\
(\mathrm{x}-\mathrm{dna} 152)\end{array}$ & KF 688042 & - \\
\hline Trichodactylus cf. crassus & $\begin{array}{l}\text { Elísio Medrado, } \\
\text { Bahia }\end{array}$ & $\begin{array}{l}\text { CCDB } 3751 \\
(x-d n a 34)\end{array}$ & KF688009 & KF688061 \\
\hline Trichodactylus cf. crassus & $\begin{array}{l}\text { Elísio Medrado, } \\
\text { Bahia }\end{array}$ & $\begin{array}{l}\text { CCDB } 3938 \\
(x-d n a ~ 81)\end{array}$ & KF688024 & KF 688078 \\
\hline Trichodactylus cf. crassus & Elísio Medrado & $\begin{array}{l}\text { CCDB } 3751 \\
(x-d n a 129)\end{array}$ & KF688036 & KF 688075 \\
\hline Trichodactylus sp. & Ilhéus, Bahia & $\begin{array}{l}\text { CCDB 3039) } \\
\text { (x-dna 83) }\end{array}$ & KF688026 & - \\
\hline Trichodactylus sp. & Itacaré, Bahia & $\begin{array}{l}\text { CCDB } 1773 \\
\text { (x-dna } 79)\end{array}$ & - & KF 688076 \\
\hline Trichodactylus sp. & Ilhéus, Bahia & $\begin{array}{l}\text { CCDB } 929 \\
(x-d n a ~ 38)\end{array}$ & - & KF688090 \\
\hline Trichodactylus sp. & Ilhéus, Bahia & $\begin{array}{l}\text { CCDB } 4529 \\
(\mathrm{x}-\text { dna } 159)\end{array}$ & - & KF688087 \\
\hline Trichodactylus cf. crassus & Varzedo, Bahia & $\begin{array}{l}\text { CCDB } 3937 \\
(x-d n a ~ 80)\end{array}$ & KF688023 & - \\
\hline Trichodactylus cf. crassus & Varzedo, Bahia & $\begin{array}{l}\text { CCDB } 3937 \\
(x-d n a 131)\end{array}$ & KF 688037 & KF 688077 \\
\hline Trichodactylus cf. crassus & Varzedo, Bahia & $\begin{array}{l}\text { CCDB } 3937 \\
(x-d n a 145)\end{array}$ & KF 688040 & - \\
\hline Trichodactylus cf. crassus & $\begin{array}{l}\text { Entre Rios, } \\
\text { Bahia }\end{array}$ & $\begin{array}{l}\text { CCDB } 4527 \\
\text { (x-dna } 158)\end{array}$ & KF 688046 & - \\
\hline Trichodactylus cf. crassus & Estância, Sergipe & $\begin{array}{l}\text { CCDB } 4528 \\
(\mathrm{x}-\mathrm{dna} 157)\end{array}$ & KF 688045 & - \\
\hline Trichodactylus sp. 4 & $\begin{array}{l}\text { São Miguel } \\
\text { Arcanjo, São } \\
\text { Paulo }\end{array}$ & $\begin{array}{l}\text { CCDB } 2679 \\
(\mathrm{x}-\mathrm{dna} 46)\end{array}$ & KF688015 & - \\
\hline Trichodactylus sp. 4 & $\begin{array}{l}\text { Tapiraí, São } \\
\text { Paulo }\end{array}$ & $\begin{array}{l}\text { CCDB 2664 } \\
(x-d n a ~ 82)\end{array}$ & KF 688025 & - \\
\hline Trichodactylus sp. 4 & Buri, São Paulo & $\begin{array}{l}\text { MZUSP } 15144 \\
(x-d n a 163)\end{array}$ & KF 688047 & - \\
\hline Trichodactylus sp. 4 & $\begin{array}{l}\text { Camboriú, Santa } \\
\text { Catarina }\end{array}$ & $\begin{array}{l}\mathrm{CCDB} 4460 \\
(\mathrm{x}-\mathrm{dna} 120)\end{array}$ & - & KF688086 \\
\hline
\end{tabular}


Tabela II. Continuação

\begin{tabular}{|c|c|c|c|c|}
\hline \multirow[t]{2}{*}{ Táxon } & \multirow[t]{2}{*}{ Localidade } & \multirow[t]{2}{*}{$\begin{array}{l}\text { Tombo em } \\
\text { Coleção }\end{array}$} & \multicolumn{2}{|c|}{ GenBank } \\
\hline & & & $16 \mathrm{~S}$ & COI \\
\hline Trichodactylus sp. 4 & $\begin{array}{l}\text { Maquiné, Rio } \\
\text { Grande do Sul }\end{array}$ & $\begin{array}{l}\text { UFRGS } 3863 \\
\text { (x-dna 66) }\end{array}$ & KF688017 & - \\
\hline Trichodactylus sp. 4 & $\begin{array}{l}\text { Terra de Areia, } \\
\text { Rio Grande do } \\
\text { Sul }\end{array}$ & $\begin{array}{l}\text { UFRGS } 2233 \\
\text { (x-dna 69) }\end{array}$ & KF688019 & KF688072 \\
\hline Trichodactylus sp. 4 & $\begin{array}{l}\text { Osório, Rio } \\
\text { Grande do Sul }\end{array}$ & $\begin{array}{l}\text { UFRGS } 2949 \\
\text { (x-dna } 67)\end{array}$ & - & KF688070 \\
\hline Trichodactylus sp. 4 & $\begin{array}{l}\text { Jaraguá do Sul, } \\
\text { Santa Catarina }\end{array}$ & $\begin{array}{l}\text { UFRGS } 2380 \\
\text { (x-dna } 70)\end{array}$ & - & KF688073 \\
\hline Trichodactylus sp. 4 & $\begin{array}{l}\text { Blumenau, Santa } \\
\text { Catarina }\end{array}$ & $\begin{array}{l}\text { UFRGS } 3567 \\
\text { (x-dna 68) }\end{array}$ & KF688018 & KF 688071 \\
\hline Trichodactylus sp. 4 & $\begin{array}{l}\text { Siderópolis, } \\
\text { Santa Catarina }\end{array}$ & $\begin{array}{l}\text { INPA } 1963 \\
(\mathrm{x}-\mathrm{dna} 74)\end{array}$ & KF688020 & - \\
\hline $\begin{array}{l}\text { Trichodactylus petropolitanus } \\
\text { (Goldi, 1886) }\end{array}$ & $\begin{array}{l}\text { Camboriú, Santa } \\
\text { Catarina }\end{array}$ & $\begin{array}{l}\text { CCDB } 4461 \\
(\mathrm{x}-\mathrm{dna} 121)\end{array}$ & KF688051 & - \\
\hline Trichodactylus petropolitanus & $\begin{array}{l}\text { Juréia-Itatins, } \\
\text { São Paulo }\end{array}$ & $\begin{array}{l}\text { CCDB } 2672 \\
\text { (x-dna } 19)\end{array}$ & KF688004 & KF688056 \\
\hline Trichodactylus petropolitanus & $\begin{array}{l}\text { Santana do } \\
\text { Parnaíba, São } \\
\text { Paulo }\end{array}$ & $\begin{array}{l}\text { CCDB } 2668 \\
(x-d n a ~ 17)\end{array}$ & KF688003 & KF688055 \\
\hline Trichodactylus petropolitanus & $\begin{array}{l}\text { Angra dos Reis, } \\
\text { Rio de Janeiro }\end{array}$ & $\begin{array}{l}\text { CCDB } 2228 \\
(\mathrm{x}-\text { dna } 91)\end{array}$ & KF688050 & - \\
\hline Trichodactylus petropolitanus & $\begin{array}{l}\text { Praia Grande, } \\
\text { São Paulo }\end{array}$ & $\begin{array}{l}\text { CCDB } 3637 \\
(x-d n a 92)\end{array}$ & KF688029 & KF688082 \\
\hline $\begin{array}{l}\text { Trichodactylus faxoni } \\
\text { Rathbun, } 1905\end{array}$ & $\begin{array}{l}\text { Lago Ipixuna, } \\
\text { Amazonas }\end{array}$ & $\begin{array}{l}\text { CCDB } 3135 \\
(x-d n a 90)\end{array}$ & KF688028 & KF688081 \\
\hline $\begin{array}{l}\text { Trichodactylus panoplus (von } \\
\text { Martens, 1869) }\end{array}$ & $\begin{array}{l}\text { Santa Maria, Rio } \\
\text { Grande do Sul }\end{array}$ & $\begin{array}{l}\text { CCDB } 2684 \\
(\mathrm{x}-\mathrm{dna} 25 \mathrm{pa})\end{array}$ & KF688005 & KF688058 \\
\hline $\begin{array}{l}\text { Trichodactylus borellianus } \\
\text { Nobili, } 1896\end{array}$ & $\begin{array}{l}\text { Aquidauana, } \\
\text { Mato Grosso }\end{array}$ & $\begin{array}{l}\text { CCDB } 2792 \\
(x-d n a ~ 89)\end{array}$ & - & KF688080 \\
\hline $\begin{array}{l}\text { Sylviocarcinus devillei } \mathrm{H} . \\
\text { Milne Edwards, } 1853\end{array}$ & $\begin{array}{l}\text { Nova Xavantina, } \\
\text { Mato Grosso }\end{array}$ & $\begin{array}{l}\text { CCDB } 2300 \\
\text { (x-dna 98) }\end{array}$ & - & KF688091 \\
\hline $\begin{array}{l}\text { Sylviocarcinus pictus (H. } \\
\text { Milne Edwards, 1853) }\end{array}$ & $\begin{array}{l}\text { Santa Maria do } \\
\text { Pará, Pará }\end{array}$ & $\begin{array}{l}\text { CCDB } 4344 \\
(\mathrm{x}-\mathrm{dna} 126)\end{array}$ & KF688053 & KF688092 \\
\hline $\begin{array}{l}\text { Valdivia serrata White, } \\
1847\end{array}$ & $\begin{array}{l}\text { Estrada para } \\
\text { Salinópolis, Pará }\end{array}$ & $\begin{array}{l}\text { CCDB } 4343 \\
(\mathrm{x}-\text { dna } 125)\end{array}$ & KF688052 & - \\
\hline
\end{tabular}


Análise de distância genética

A fim de avaliar a taxa de variação intra e interespecífica das populações de $T$. fluviatilis, distâncias genéticas foram calculadas por distância p usando o software MEGA 5.05 (Tamura et al., 2011).

\section{Análises filogenéticas}

Com o intuito de checar a validade da espécie reconhecida morfologicamente como T. fluviatilis foram realizadas análises filogenéticas utilizando como critérios de Máxima Verossimilhança (Máximo Likelihood - ML) (Felsenstein, 1981) e Inferência Bayesiana (Huelsenbeck \& Ronquist, 2001) para ambos os genes.

Os modelos de substituição foram selecionados, segundo o critério Bayesian Information Criterion (BIC), dentre as 88 alternativas disponíveis pelo programa jModelTest 2.1.4 (Guindon \& Gascuel, 2003; Darriba et al., 2012).

A análise de Máxima Verossimilhança foi realizada no programa RAxML (7.2.7) (Stamatakis, 2006) implementado no CIPRES ("Cyberinfrastructure for Phylogenetic Research") (http://www.phylo.org). A consistência das topologias foi avaliada pelo método de "bootstrap" (Felsenstein, 1985) com 1000 réplicas e, apenas valores de confiança acima de 50\% foram apresentados.

A Inferência Bayesiana foi realizada com o programa MrBayes v. 3.1 (Huelsenbeck \& Ronquist, 2001). A análise bayesiana foi configurada para utilizar os seguintes parâmetros: frequência de amostragem igual a 500, quatro cadeias de aquecimento, modelo de substituição assumido foi o General Time Riversible (GTR) + Gamma $(\mathrm{G})$ + Proporção Invariante (I), grupo externo escolhido valor da parada de aquecimento das cadeias menor que 0, 01 depois de no mínimo 1.000.000 de gerações. Posteriormente, a fase pré-estacionária de distribuição foi descartada (burnin=10\%). Posteriormente, foi realizada a análise dos resultados utilizando-se o consenso da 
maioria das árvores geradas. Os valores de suporte dos ramos foram obtidos pelo método de probabilidade a posteriori. As árvores geradas de ambas as análises foram salvas e editadas no MEGA 5.05 (Tamura et al., 2011) e Photoshop CS3.

\subsection{Obtenção dos dados morfológicos}

Previamente às análises, a identificação dos exemplares foi confirmada com base nas características morfológicas diagnósticas da espécie (Latreille, 1828; Magalhães, 2003).

Em laboratório, todos os indivíduos tiveram seu sexo verificado com base na forma do abdome. A diferenciação de jovens e adultos foi realizada com base na forma do abdome e aderência dos somitos abdominais aos esternitos torácicos.

Todas as análises morfológicas foram realizadas sob estereomicroscópio $\left(\right.$ LEICA $^{\circledR}$ DFC 295) e em sua maioria no Laboratório de Bioecologia e Sistemática de Crustáceos (LBSC), na FFCLRP/USP, ou nas instituições anteriormente mencionadas quando da impossibilidade de empréstimos ou de um número elevado de lotes para transporte.

Foram analisados os caracteres diagnósticos descritos para a espécie e outros caracteres considerados informativos (Figura 3; Tabela III). Após a identificação dos caracteres de maior variação, foi realizada uma análise comparativa entre as populações.

Os desenhos das estruturas que apresentaram maior variação foram realizados com uma câmara clara acoplada ao estereomicroscópio (LEICA ${ }^{\circledR}$ MZ6). Posteriormente, esses desenhos foram digitalizados por meio de um scanner (HP Photosmart C3180) e editados programa de edição de imagens Adobe Photoshop CS3 (Adobe System ${ }^{\circledR}$ ). 
Tabela III - Lista de caracteres utilizados na análise morfológica de exemplares do complexo Trichodactylus fluviatilis provenientes de diferentes localidades no Brasil.

\section{Lista de caracteres morfológicos}

Carapaça: forma, presença ou ausência de dentes e entalhes na margem ânterolateral

Margem ântero-lateral da carapaça: lisa ou com grânulos Margem pôstero-lateral da carapaça: lisa ou com grânulos Região frontal: reta ou bilobada, presença ou ausência de grânulos Quelípodo: tamanho do própodo e palma, presença ou ausência de espinho no carpo e mero, comprimento do dáctilo e palma, presença e/ou ausência de dentes lobulares

Órbita inferior: presença ou ausência de grânulos

Órbita superior: presença ou ausência de grânulos e dentes

Antena: número de segmentos da antena

Crista bucal: lisa ou granulada

Abdome masculino: forma, largura e altura do telson e sexto somito abdominal

Gonópodo: forma, disposição dos espinhos nas faces lateral e mesial da porção distal, abertura distal, forma do ápice do gonópodo, sutura marginal, constrição mediana, proeminência e contorno dos bordos laterais, comprimento da porção distal e proximal.

Para análise morfológica do gonópodo 1, estrutura taxonomicamente muito importante e bastante utilizada na identificação das espécies de caranguejos dulcícolas (Ng, 1988; Magalhães, 1991; Cumberlidge, 1999; Magalhães, 2003; Jesse et al., 2010), estes foram dissecados e inicialmente analisados sob estereomicroscópio. Os caracteres 
analisados foram os já descritos na literatura (Figura 4). Posteriormente as amostras foram desidratadas em banhos de álcool 80,90 e $100 \%$ por 20 minutos cada, sendo o último banho de $100 \%$ repetido três vezes. Após esta etapa, as amostras foram submetidas à secagem em ponto crítico de $\mathrm{CO}_{2}$ líquido com EMS 850 (Electron Microscopy Sciences $\left.{ }^{\circledR}\right)$, montadas em stubs e recobertas por uma fina camada de ouro 24k em um metalizador Denton Vacuum Desk II. As fotografias foram feitas com microscópio eletrônico de varredura (MEV) JSM $5410\left(\mathrm{JEOL}^{\circledR}\right)$ no Laboratório de Microscopia Eletrônica da Faculdade de Ciências Agrárias e Veterinárias, UNESP, Jaboticabal. As micrografias eletrônicas foram digitalizadas e editadas no programa de edição de imagens Adobe Photoshop CS3 (Adobe System ${ }^{\circledR}$ ). 


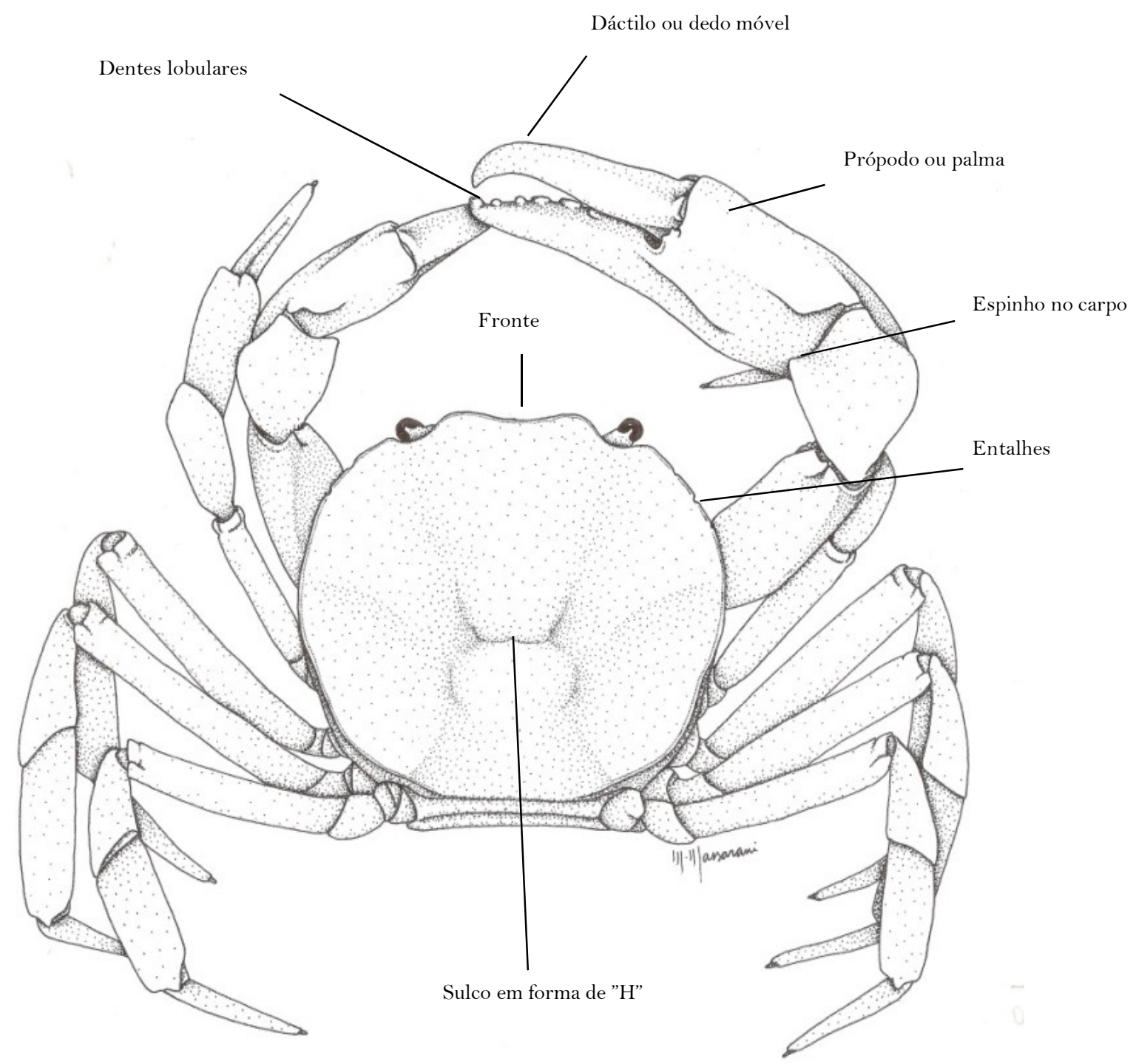

Figura 3. Desenho esquemático da morfologia externa do caranguejo Trichodactylus fluviatilis com destaque para algumas estruturas utilizadas na identificação da espécie (MNRJ 19149, ठૈ, LC $39.52 \mathrm{~mm})$. 


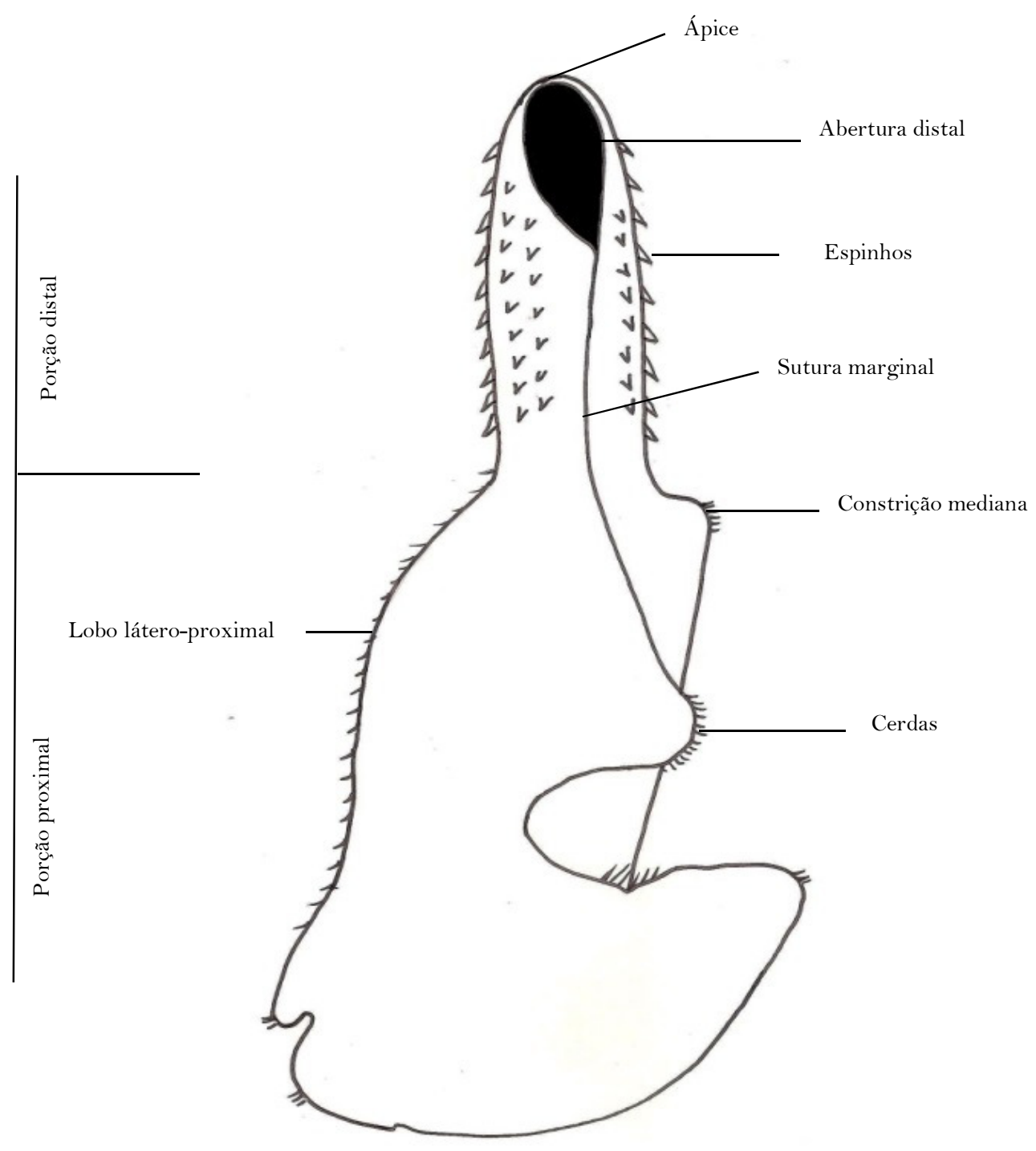

Figura 4. Desenho esquemático da morfologia de um gonópodo do caranguejo Trichodactylus fluviatilis com destaque para as estruturas utilizadas na identificação da espécie (MNRJ 19149, $\widehat{\jmath}$, LC $39.52 \mathrm{~mm})$. 


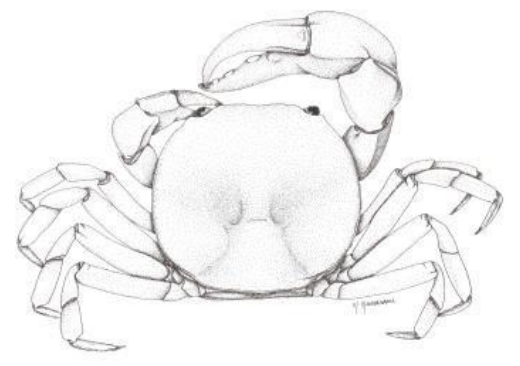

4. RESULTADOS 


\subsection{Análise molecular}

Foram obtidas sequências parciais inéditas do gene mitocondrial 16S com 560 pb provenientes de 52 exemplares, sendo 43 de $T$. fluviatilis e 9 de outras espécies pertencentes à família Trichodactylidae: T. petropolitanus, T. panoplus, T. faxoni. Sylviocarcinus devillei, Valdivia serrata. Para o COI foram obtidas sequências inéditas com 660 pb provenientes de 36 indivíduos, sendo 30 de T. fluviatilis e 6 de outras espécies pertencentes a família: $T$. petropolitanus, $T$. panoplus e $T$. borellianus e $T$. faxoni, Sylviocarcinus pictus, S. devillei e $V$. serrata.

Análises de distância

As sequências do $16 \mathrm{~S}$ não foram idênticas apresentando divergências genéticas bem significativas, sendo que a taxa de divergência interespecífica variou de 5.1 a 10.25\%. Para o gene COI essa taxa variou de 8.8 a 13.5\% (Tabelas IV, V). 
Tabela IV. Matriz de divergência genética entre os clados encontrada para o gene 16S (rRNA) nos exemplares do complexo T. fluviatilis, calculado no MEGA com distância p. Média ( \pm erro padrão). SP: São Paulo; RJ: Rio de Janeiro; MG: Minas Gerais; ES: Espírito Santo; BA: Bahia (região do recôncavo e norte); AL: Alagoas; SE: Sergipe; sul do Brasil (SC: Santa Catarina; PR: Paraná; RS: Rio Grande do Sul).

\begin{tabular}{|c|c|c|c|c|c|c|}
\hline & 1 & 2 & 3 & 4 & 5 & 6 \\
\hline \multicolumn{7}{|l|}{$\begin{array}{l}\text { 1- Trichodactylus sp. } 1 \\
\text { (Planície-costeira } \\
\text { Cananéia-Iguape - SP) }\end{array}$} \\
\hline $\begin{array}{l}\text { 2- T. fluviatilis "sensu } \\
\text { stricto" (RJ, SP) }\end{array}$ & $\begin{array}{c}6.7 \% \\
( \pm 0.9)\end{array}$ & & & & & \\
\hline $\begin{array}{l}\text { 3- Trichodactylus aff. } \\
\text { fluviatilis (rio Paraíba do } \\
\text { Sul - RJ e MG) }\end{array}$ & $\begin{array}{c}5.1 \% \\
( \pm 0.9)\end{array}$ & $\begin{array}{c}6.2 \% \\
( \pm 0.8)\end{array}$ & & & & \\
\hline $\begin{array}{l}\text { 4- Trichodactylus sp. } 2 \text { (Sul } \\
\text { da Bahia) }\end{array}$ & $\begin{array}{l}7.0 \% \\
( \pm 1.0)\end{array}$ & $8.1 \%( \pm 1.0)$ & $\begin{array}{c}7.5 \% \\
( \pm 1.0)\end{array}$ & & & \\
\hline 5- Trichodactylus sp. 3 (ES) & $\begin{array}{l}8.7 \% \\
( \pm 1.0)\end{array}$ & $\begin{array}{c}10 \% \\
( \pm 1.0)\end{array}$ & $\begin{array}{l}9.6 \% \\
( \pm 1.0)\end{array}$ & $\begin{array}{l}7.5 \% \\
( \pm 0.9)\end{array}$ & & \\
\hline $\begin{array}{l}\text { 6- Trichodactylus cf. crassus } \\
\text { (BA, AL, SE) }\end{array}$ & $\begin{array}{l}8.2 \% \\
( \pm 1.0)\end{array}$ & $\begin{array}{l}10.25 \% \\
( \pm 1.0)\end{array}$ & $\begin{array}{l}9.2 \% \\
( \pm 1.0)\end{array}$ & $\begin{array}{l}8.5 \% \\
( \pm 1.0)\end{array}$ & $\begin{array}{l}9.3 \% \\
( \pm 1.0)\end{array}$ & \\
\hline $\begin{array}{l}\text { 7- Trichodactylus sp. } 4 \text { (sul } \\
\text { de SP e sul do Brasil) }\end{array}$ & $\begin{array}{l}7.0 \% \\
( \pm 0.9)\end{array}$ & $\begin{array}{l}8.4 \% \\
( \pm 0.9)\end{array}$ & $\begin{array}{l}7.4 \% \\
( \pm 0.9)\end{array}$ & $\begin{array}{c}7.1 \% \\
( \pm 0.9)\end{array}$ & $\begin{array}{l}9.0 \% \\
( \pm 0.8)\end{array}$ & $\begin{array}{c}7.1 \% \\
( \pm 1.0)\end{array}$ \\
\hline
\end{tabular}


Tabela V. Matriz de divergência genética entre os clados encontrada para o gene COI (rRNA) nos exemplares do complexo $T$. fluviatilis, calculado no MEGA com distância p. Média ( \pm erro padrão). SP: São Paulo; RJ: Rio de Janeiro; MG: Minas Gerais; ES: Espírito Santo; BA: Bahia (região do recôncavo e norte); AL: Alagoas; SE: Sergipe; sul do Brasil (SC: Santa Catarina; PR: Paraná; RS: Rio Grande do Sul).

\begin{tabular}{lccccc}
\hline & & & & & \\
& $\mathbf{1}$ & $\mathbf{2}$ & $\mathbf{3}$ & $\mathbf{4}$ & $\mathbf{5}$ \\
\hline $\begin{array}{l}\text { 1- T. fluviatilis sensu stricto } \\
\text { (RJ e SP) }\end{array}$ & & & & \\
2- Trichodactylus aff. & & & & & \\
fluviatilis (rio Paraíba do Sul & $9.0 \%$ & & & & \\
- RJ e MG) & $( \pm 0.9)$ & & & & \\
3- Trichodactylus sp. 1 & & & & & \\
(Planície costeira Cananéia- & $8.8 \%$ & $9.6 \%$ & & & \\
Iguape - SP) & $( \pm 1.0)$ & $( \pm 1.0)$ & & & \\
4- Trichodactylus sp. 4 (sul de & $10.7 \%$ & $9.6 \%$ & $10.6 \%$ & & \\
SP e sul do Brasil) & $( \pm 0.9)$ & $( \pm 0.8)$ & $( \pm 1.0)$ & & \\
5- Trichodactylus cf. crassus & $12.3 \%$ & $11.9 \%$ & $13.5 \%$ & $11.8 \%$ & \\
(BA, AL, SE) & $( \pm 1.1)$ & $( \pm 1.0)$ & $( \pm 1.2)$ & $( \pm 1.0)$ & \\
6- Trichodactylus sp. 2 (sul & $12.6 \%$ & $12.2 \%$ & $13.5 \%$ & $12.2 \%$ & \\
da Bahia) & $( \pm 1.1)$ & $( \pm 1.1)$ & $( \pm 1.3)$ & $( \pm 1.1)$ & $13 \%( \pm 1.2)$ \\
\hline
\end{tabular}

\section{Análises filogenéticas}

$\mathrm{O}$ modelo de substituição mais adequado para as sequências do gene $16 \mathrm{~S}$ foi o General Time Riversible (GTR) + Gamma (G) + Proporção Invariante (I), com os seguintes parâmetros: frequência das bases, $\mathrm{A}=0.3723, \mathrm{C}=0.1020, \mathrm{G}=0.1723, \mathrm{~T}=$ 0.3533; proporção de sítios invariáveis $=0.1050$ e sítios variáveis seguindo distribuição gama com parâmetro $=0.4470$. Para o gene COI o modelo mais adequado também foi GTR $+\mathrm{G}+\mathrm{I}$, com os seguintes parâmetros: frequência das bases, $\mathrm{A}=0.3249, \mathrm{C}=$ $0.1733, \mathrm{G}=0.1105, \mathrm{~T}=0.3912$; proporção de sítios invariáveis $=0.5560$ e sítios variáveis seguindo distribuição gama com parâmetro $=0.8890$.

A filogenia baseada em sequências do $16 \mathrm{~S}$ revelou a formação de clados geneticamente bem distintos (Figuras 5, 6): clado T. fluviatilis sensu stricto formado por 
indivíduos de São Paulo e região litorânea do Rio de Janeiro; clado I (Trichodactylus sp. 1) - formado por indivíduos provenientes da planície costeira Cananéia-Iguape (Cananéia-SP); clado II (Trichodactylus aff. fluviatilis) - formado por indivíduos oriundos da bacia hidrográfica do rio Paraíba do Sul (Minas Gerais, Rio de Janeiro); clado III (Trichodactylus sp. 2) - formado por indivíduos da macrorregião hidrográfica do Atlântico Leste (extremo sul da Bahia); clado IV (Trichodactylus sp. 3) - formado por indivíduos do Espírito Santo; clado V (Trichodactylus cf. crassus) - formado por indivíduos provenientes da macrorregião hidrográfica do Atlântico Leste (sul, Recôncavo e norte da Bahia e Sergipe); clado VI (Trichodactylus sp. 4) - formado por indivíduos da bacia do Paraná e Atlântico Sudeste (sul de São Paulo e sul do Brasil).

No clado V, apenas para o gene 16S, os indivíduos de Ilhéus (BA) (CCDB 4529) apresenta-se geneticamente bem distante dos demais espécimes do mesmo clado.

O clado VI é formado por indivíduos de áreas geográficas distintas (sul de São Paulo e sul do Brasil). Embora sejam de áreas distintas esses indivíduos não puderam ser separados morfologicamente, por isso foram considerados como um único clado. Esse grupo morfológico apresentou-se monofilético para o gene 16S. Entretanto, para o gene COI (Figuras 7, 8) esse grupo não apresentou-se monofilético, sendo dividido em um clado formado por indivíduos de Santa Catarina e outro por espécimes do Rio Grande do Sul.

Em ambas as análises filogenéticas, BI e ML, a espécie T. petropolitanus foi alocada entre os clados reconhecidos morfologicamente como T. fluviatilis. 


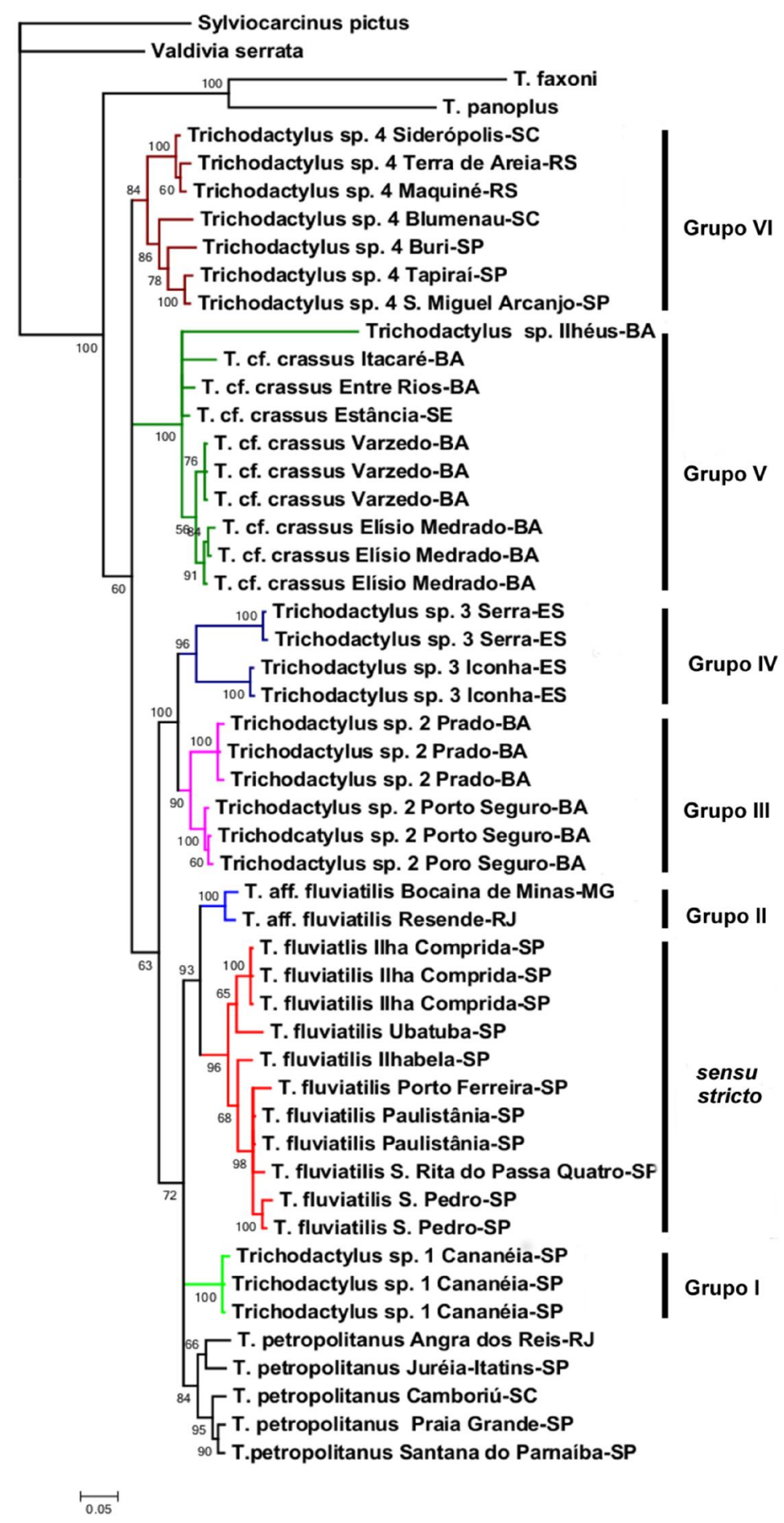

Figura 5. Relação filogenética entre populações do complexo T. fluviatilis baseada em Inferência Bayesiana obtida pela análise de sequências parciais do gene $16 \mathrm{~S}$ (rRNA). Valores do nó representam probabilidade a posteriori ( $\leq 50 \%$ não apresentados); BA: Bahia; ES: Espírito Santo; MG: Minas Gerais; RJ: Rio de Janeiro; SC: Santa Catarina; SE: Sergipe; SP: São Paulo; RS: Rio Grande do Sul. 


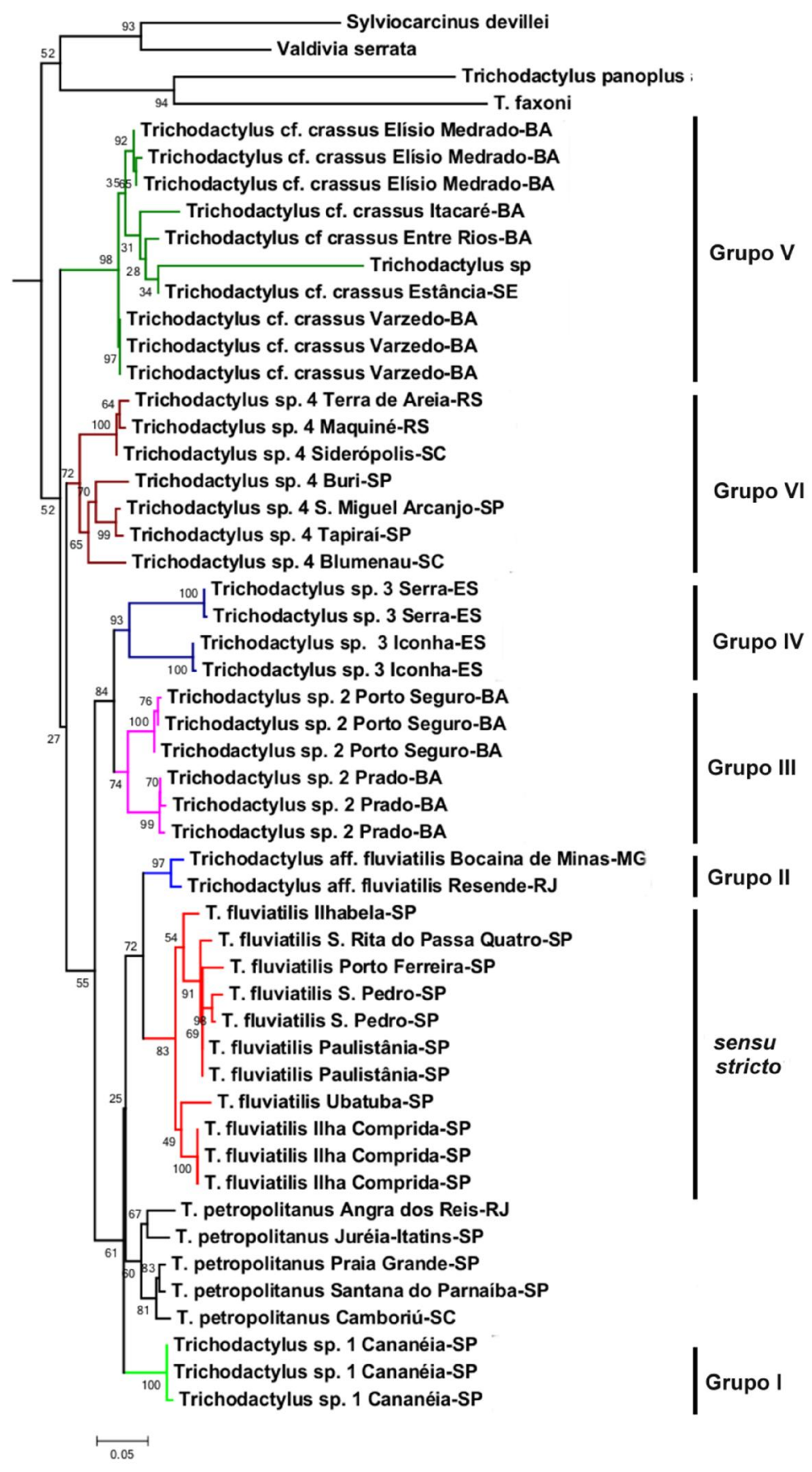

Figura 6. Relação filogenética entre populações do complexo T. fluviatilis baseada em Máxima Verossimilhança obtida pela análise de sequências parciais do gene 16S (rRNA). Valores do nó representam o suporte de bootstrap ( $\leq 50 \%$ não apresentados); BA: Bahia; ES: Espírito Santo; MG: Minas Gerais; RJ: Rio de Janeiro; SC: Santa Catarina; SE: Sergipe; SP: São Paulo; RS: Rio Grande do Sul. 


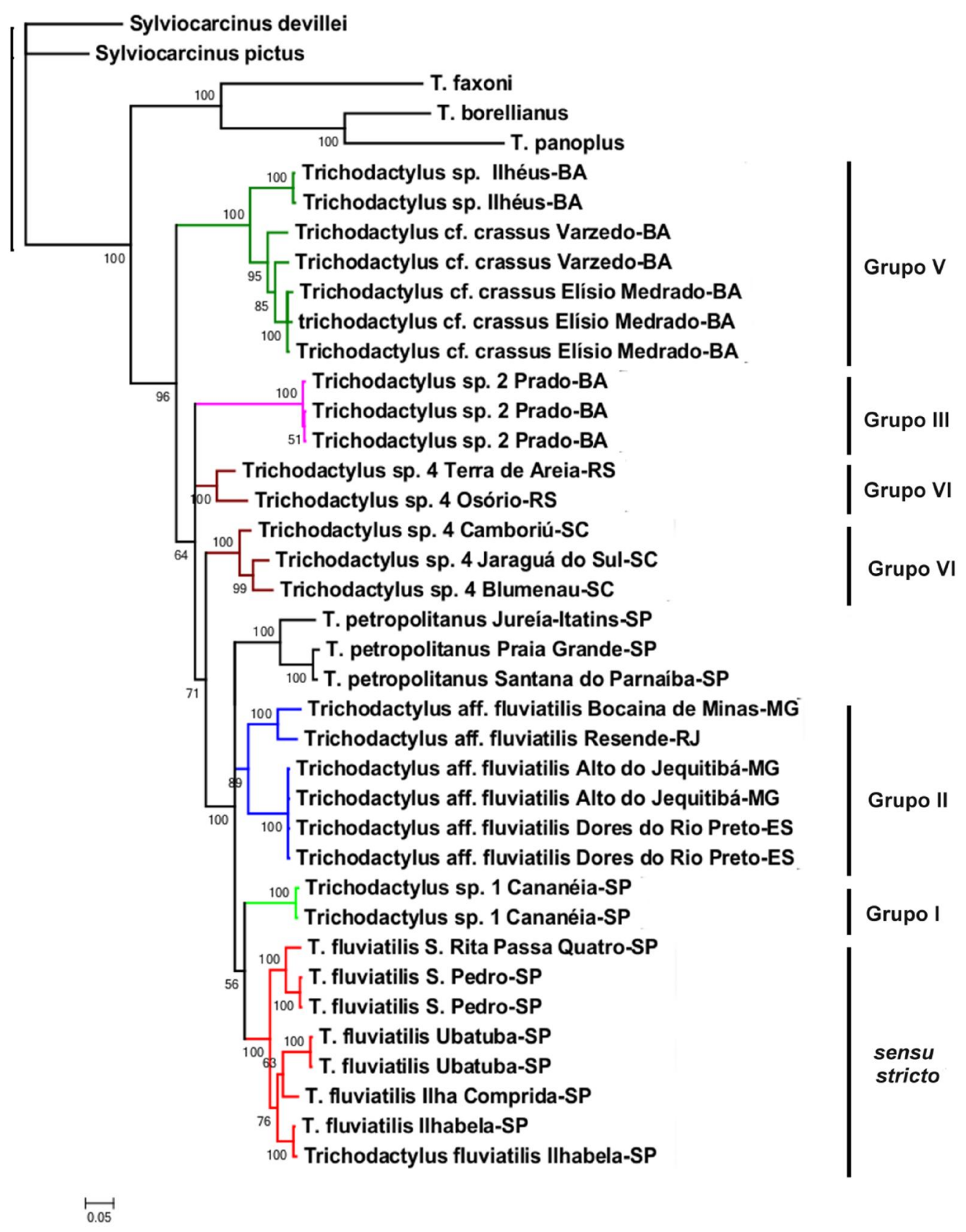

Figura 7. Relação filogenética entre populações do complexo T. fluviatilis baseada em Inferência Bayesiana obtida pela análise de sequências parciais do gene COI (rRNA). Valores do nó representam probabilidade a posteriori ( $\leq 50 \%$ não apresentados); BA: Bahia; ES: Espírito Santo; MG: Minas Gerais; RJ: Rio de Janeiro; SC: Santa Catarina; SE: Sergipe; SP: São Paulo; RS: Rio Grande do Sul. 


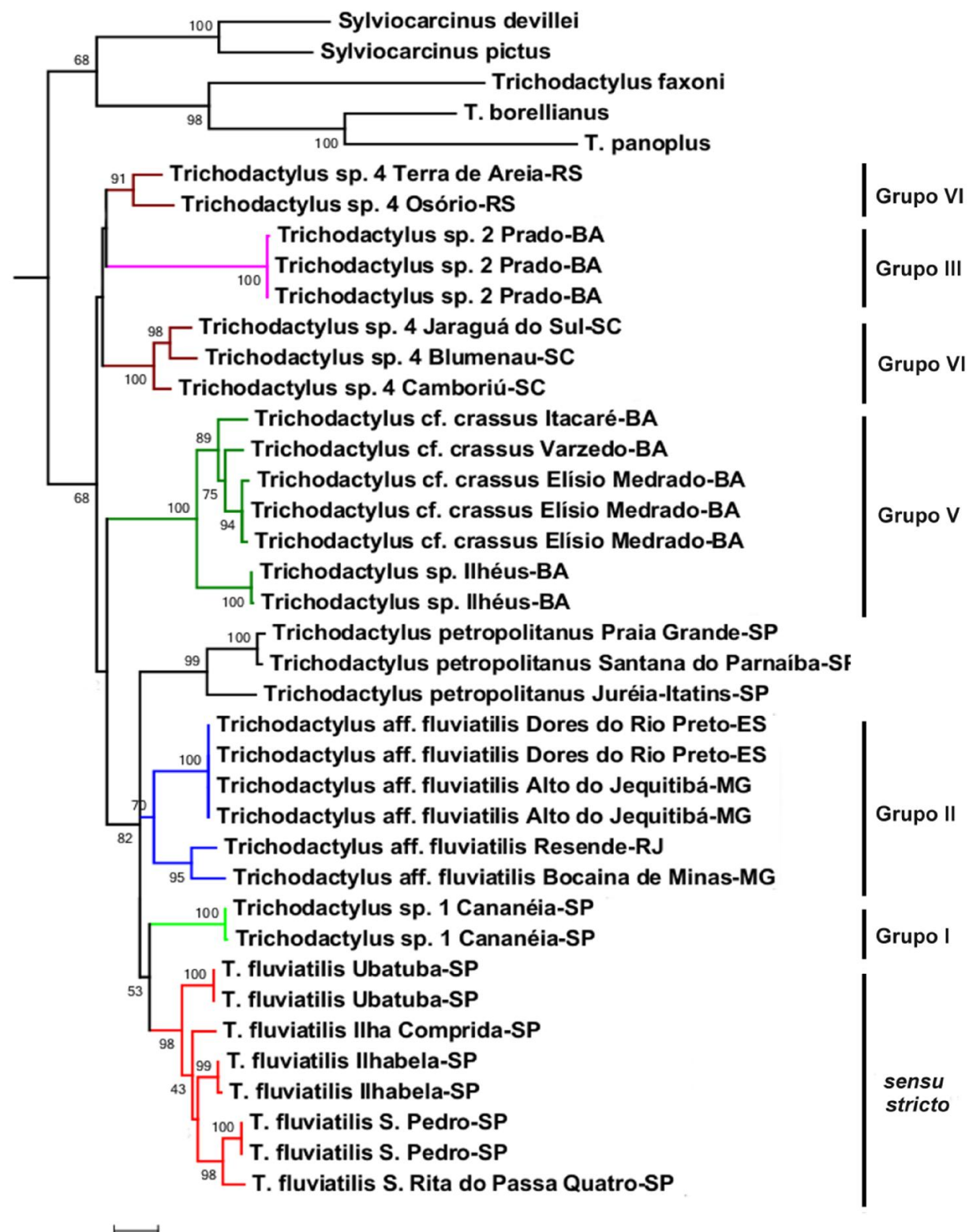

$\stackrel{\longmapsto}{0.1}$

Figura 8. Relação filogenética entre populações do complexo T. fluviatilis baseada em Máxima Verossimilhança obtida pela análise de sequências parciais do gene COI (rRNA). Valores do nó representam o suporte de bootstrap ( $\leq 50 \%$ não apresentados); BA: Bahia; ES: Espírito Santo; MG: Minas Gerais; RJ: Rio de Janeiro; SC: Santa Catarina; SE: Sergipe; SP: São Paulo; RS: Rio Grande do Sul. 


\subsection{Análise morfológica}

Foram analisados 146 espécimes do complexo T. fluviatilis (106 machos e 40 fêmeas) oriundos de diferentes localidades no Brasil (Figura 9).

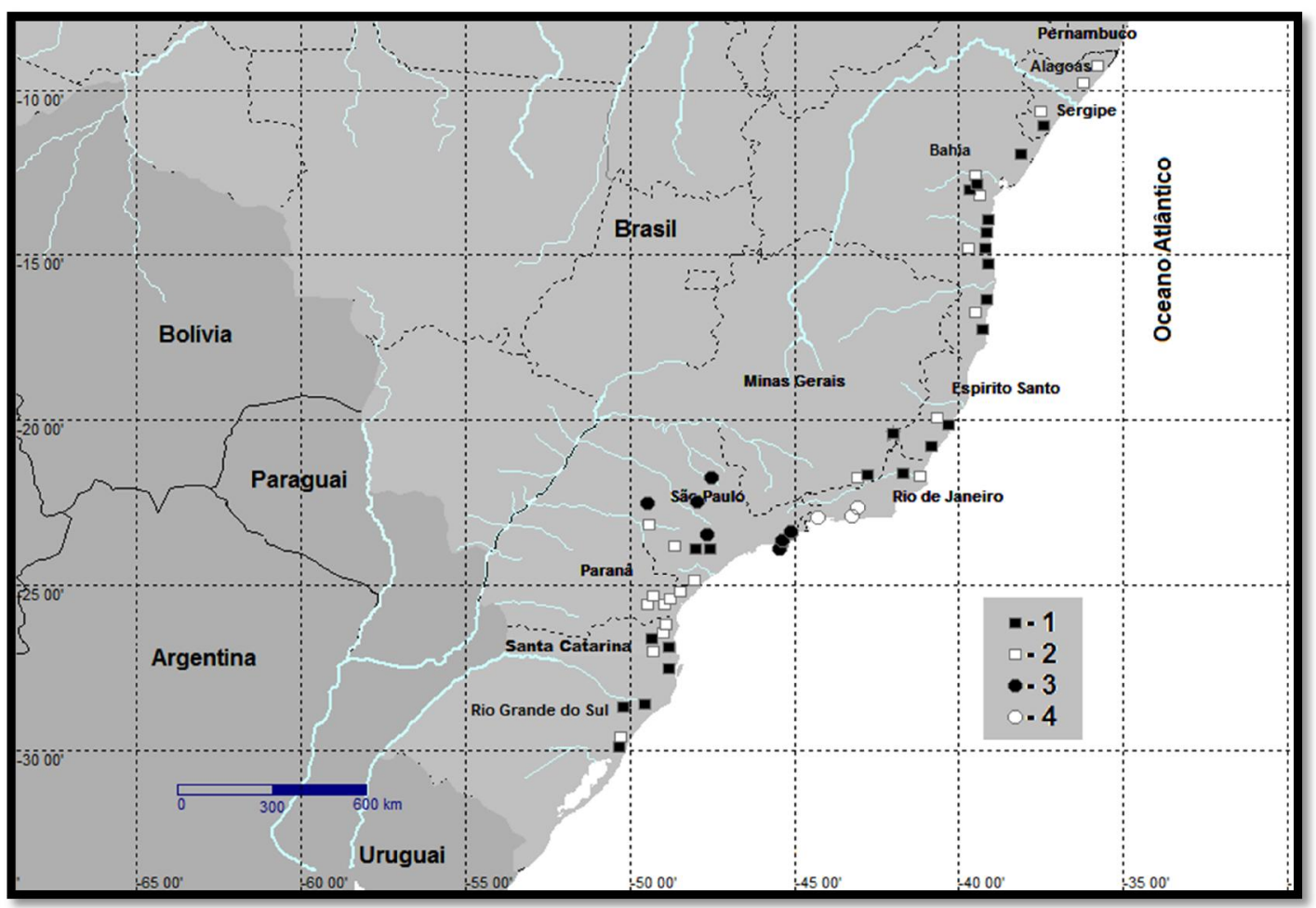

Figura 9. Mapa com a distribuição do complexo T. fluviatilis analisados neste trabalho. 1espécimes utilizados nas análises morfológicas e moleculares, 2- espécimes utilizados na análise morfológica, 3- exemplares de Trichodactylus fluviatilis sensu stricto utilizados nas análises morfológicas e moleculares, 4- exemplares de Trichodactylus fluviatilis sensu stricto utilizados nas análises morfológicas. 


\section{$\underline{\text { Taxonomia }}$}

Subfilo Crustacea Pennant, 1777

Ordem Decapoda Latreille, 1803

Subordem Pleocyemata Burkenroad, 1963

Infraordem Brachyura Latreille, 1803

Superfamília Trichodactyloidea H. Milne Edwards, 1853

Família Trichodactylidae H. Milne Edwards, 1853

Subfamília Trichodactylinae H. Milne Edwards, 1853

Gênero Trichodactylus Latreille, 1828

\section{Trichodactylus fluviatilis Latreille, 1828}

Figuras: 10 A, B; 15 A, D e B, E; 18 A

Material-tipo: Não examinado.

Material examinado: Rio de Janeiro. $2 \hat{\jmath}$, Barra de São João, col. A. Giupponi (MNRJ19149); 10̄, Fazenda Cachoeira, Porciúncula, col. J. Decker (MNRJ 1229); 10̂, Rio de Janeiro, coletor desconhecido (MNRJ 1116); 1, Floresta da Tijuca, Rio de Janeiro, coletor desconhecido (MZUSP 2278); 10ิ, Rio de Janeiro, coletor desconhecido

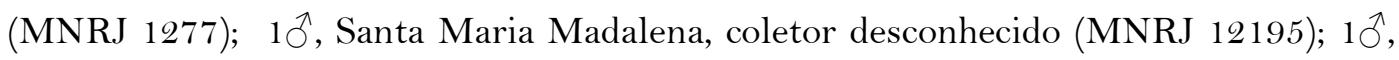
Reserva do Tinguá, Itaguaí, coletor desconhecido (MNRJ 1211). São Paulo. 2 đે, Poço da Escada, São Sebastião, col. E. Mossolin (CCDB 2071); 20̂, 1, Poço da Pedra, São Sebastião, Ilhabela, col. E. Mossolin (CCDB 2075); 10̂, 1q, Cachoeira da Toca, São Sebastião, Ilhabela, col. E. Mossolin (CCDB 2074); 10̄, São Miguel Arcanjo, col. Rocha \& Domingos (CCDB 2679); 2ิ̂, Rio Mogi-Guaçú, Porto Ferreira, col. E.A. Souza- 
Carvalho, et al. (CCDB 4173); 8ठ̂, Rio Mogi-Guaçú, Porto Ferreira, col. A. Costa (CCDB 2679); 10̂, estrada para praia do Itaguá, Ubatuba, col. F.L.M. Mantelatto et al. (CCDB 3879); 1ठ̂, Floresta Estadual Navarro de Andrade, Rio Claro, col. R. Rocha (MZUSP 15783); 10̄, Riviera de São Lourenço, Bertioga, col. A.G. Lima. (MZUSP 18394); 10 đ̂, Paulistânia, col. R. Caetano (CCDB 3791); 1ô, 1q, Parque Estadual de Jacupiranga, Eldorado, col. S. Rocha (MZUSP 15103); 20 , córrego da gruta do Peroba, Fazenda Santa Rita, col. S. Bueno (CCDB 1574); 1옹 Santa Rita do Passa Quatro, coletor desconhecido (CCDB 2296).

Localidade-tipo: Brasil. Provavelmente Rio de Janeiro, RJ.

Caracterização morfológica de $\boldsymbol{T}$. fluviatilis sensu stricto. Carapaça levemente subquadrada ou subcircular; mais larga do que comprida. Margem ântero-lateral da carapaça lisa, as vezes com grânulos pequenos, com 1-3 entalhes ou com 1 dente. Margem póstero-lateral da carapaça lisa. Margem frontal reta ou bilobada. Sulco em forma de "H" bem pronunciado. Margem orbital inferior lisa ou com grânulos pequenos. Crista bucal lisa, algumas vezes com grânulos pequenos. Heteroquelia presente, sendo mais acentuada nos machos; dáctilo do quelípodo maior 1,6 vezes mais longo que a palma; dentes lobulares de 4 a 7; quelípodos com um espinho obtuso ou rombudo presente na face interna do carpo; um pequeno espinho distal as vezes presente na face dorsal do mero. Antena com 10-14 segmentos. Abdome do macho subtriangular, com margens côncavas; todos os somitos abdominais livres; sexto somito abdominal 1,3 vezes mais largo que o telso. Gonópodo reto; ápice arredondado, algumas vezes levemente anguloso; abertura distal larga e voltada para o lado mesial; constrição mediana pronunciada e voltada para a porção proximal; bordo láteroproximal pouco proeminente, suavemente convexo; porção distal com o bordo lateral reto, algumas vezes pouco inflado e bordo mesial reto; sutura marginal reta. 
Distribuição: Brasil - São Paulo e região costeira do Rio de Janeiro.

Ecologia: Espécie de hábito noturno, sendo encontrada em rios, córregos, riachos, cachoeiras, sob pedras, na serrapilheira submersa ou entre as raízes de vegetação marginal. Os rios podem apresentar-se com águas bem turvas.

Medidas: maior espécime analisado: CCDB (2311) - §̂, LC 36.27 mm.

Considerações: As fêmeas algumas vezes apresentam a margem lateral e frontal com mais grânulos do que os machos. Outro fator que vale ressaltar é a coloração que estes caranguejos apresentam, embora esta não seja confiável para a identificação de muitas espécies devido a enorme variação. Nos indivíduos deste grupo a coloração encontrada variou de em tons marrom chocolate, marrom, preto, dentre outras.

\subsubsection{Variabilidade morfológica do complexo T. fluviatilis}

\section{Grupo I (planície costeira Cananéia-Iguape): Trichodactylus sp. 1}

Figuras: $11 \mathrm{~A}, 14 \mathrm{C} ; 15 \mathrm{C}, \mathrm{F} ; 18 \mathrm{C}$.

Material examinado: São Paulo: $1 \widehat{O}^{\lambda}$, rio da Cachoeira do Encanto, Cananéia, col. F.L.M. Mantelatto et al. (CCDB 3697); 2 $\widehat{\jmath}$, rio da Cachoeira do Encanto, Cananéia, col. F.L.M. Mantelatto et al. (CCDB 1772); 1 ô, rio da Cachoeira do Pitú, Cananéia, col. E.A. Souza-Carvalho et al. (CCDB 3752).

Diagnose: Carapaça marcadamente subquadrada. Carapaça com superfície lisa; margem lateral carenada; margem ântero-lateral com 1-2 entalhes; margem frontal 
reta e lisa. Margem orbital superior lisa. Crista bucal com alguns grânulos. Margem orbital inferior com pequenos grânulos. Antena com 13 segmentos. Heteroquelia presente; quelípodos com espinho na face interna do carpo. Abdome do macho com forma subtriangular e margens côncavas. Gonópodo reto e com ápice levemente anguloso; abertura distal voltada para o lado mesial; constrição mediana pouco pronunciada; bordo látero-proximal proeminente e levemente convexo; bordo mésioproximal quase reto; porção distal com o bordo lateral pouco inflado e mesial reto.

Distribuição: Cananéia, São Paulo.

Ecologia: Espécie de hábito noturno, sendo encontrada em riachos e cachoeiras, sob pedras marginais.

Medidas: maior espécime analisado: CCDB (1772) - ô, LC $27.04 \mathrm{~mm}$.

Considerações: os exemplares deste grupo apresentam a carapaça marcadamente mais subquadrada do que os demais exemplares de outros clados.

\section{Grupo II (rio Paraíba do Sul): Trichodactylus aff. fluviatilis}

Figuras: $14 \mathrm{~B}$ e $18 \mathrm{~B}$.

Material examinado: Rio de Janeiro. $2 \hat{\bigcirc}, 3+$, São Fidélis, col. F.L. Carvalho \& R. Robles (CCDB 4643); Minas Gerais. 10̂, Bocaina, col. F.L. Carvalho \& R. Robles (CCDB 4668); 10̂, rio Parnaíba do Sul, Forquilha, Senador Cortes, col. D.F. Moraes

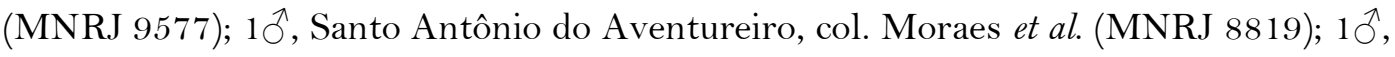


2q, Alto do Jequitibá, col. E. Mossolin (CCDB 2729). Espírito Santo. 10̂, 2q, Dores do Rio Preto, col. E. Mossolin (CCDB 2728).

Diagnose: Carapaça subcircular e/ou subquadrada. Margem ântero-lateral com 1-2 entalhes. Margem póstero-lateral lisa. Margem frontal quase reta ou bilobada, às vezes inclinada para baixo. Margem orbital superior lisa. Margem orbital inferior com grânulos. Crista bucal com grânulos. Antena com 11 segmentos. Heteroquelia presente; quelípodos com espinho presente na face interna do carpo. Abdome do macho triangular. Gonópodo reto e com ápice arredondado; abertura distal larga e voltada para o lado mesial; constrição mediana bem pronunciada; bordo látero-proximal acentuadamente convexo; bordo mésio-proximal reto; porção distal com bordo lateral levemente inflado e mesial reto.

Distribuição: Bacia do rio Paraíba do Sul. Rio de Janeiro, Minas Gerais e Espírito Santo.

Ecologia: Espécie de hábito noturno, sendo encontrada em rios e córregos, sob pedras, em buracos marginais e entre raízes de vegetação marginal. Pode ser encontrada em altitudes de até $1010 \mathrm{~m}$.

Medidas: maior espécime analisado: CCDB (4668) - đ̂, LC $32.67 \mathrm{~mm}$. 


\section{Grupo III (extremo sul da Bahia): Trichodactylus sp. 2}

Figuras: $11 \mathrm{~B}$; $14 \mathrm{D} ; 16 \mathrm{~A}, \mathrm{D} ; 18 \mathrm{D}$.

Material examinado: Bahia. $1{ }^{\Uparrow}, 2$, Estação Veracel Celulose, Porto Seguro, col. E.A. Souza-Carvalho \& F.L. Carvalho (CCDB 3294); 3ô,, Estação Veracel Celulose, Porto Seguro, col. E.A. Souza-Carvalho \& F.L. Carvalho (CCDB 1774); $2 \overbrace{}^{\Uparrow}$, 4ㅇ, rio das Palmeiras, Varzedo, col. S. Rocha (CCDB 3937); 10 $0^{\Uparrow}$, rio da Paixão, Prado, col. E.A. Souza-Carvalho \& F.L. Carvalho (CCDB 4186); 3ð̄, Prado, col. Silva \& Soares (MZUSP 10782).

Diagnose: Carapaça orbicular. Margem ântero-lateral da carapaça sem entalhes ou com 1 entalhe. Margem póstero-lateral da carapaça lisa. Margem frontal reta ou levemente bilobada e lisa; levemente inclinada para baixo. Margem orbital superior lisa. Crista bucal lisa. Margem orbital inferior lisa. Heteroquelia presente, mais acentuada nos machos; quelípodos com espinho presente na face interna do carpo. Antena com 15 segmentos. Abdome do macho subtriangular. Gonópodo reto e com ápice truncado; abertura distal subcircular; constrição mediana ausente; bordo láteroproximal pouco proeminente; bordo mésio-proximal reto; porção distal com bordo lateral e mesial reto; porção basal com um processo bem proeminente e com cerdas basais.

Distribuição: Porto Seguro e Prado, Bahia.

Ecologia: Espécie de hábito noturno, sendo encontrada em córregos e riachos, na serrapilheira submersa. 
Medidas: maior espécime analisado: CCDB (4186) - §̂ LC $25.00 \mathrm{~mm}$.

Consideração: Espécimes jovens podem apresentar até 1-2 dentes na margem ânterolateral da carapaça. Coloração roxa.

\section{Grupo IV (Espírito Santo): Trichodactylus sp. 3}

Figuras: 14 E e 18 E

Material examinado: Espírito Santo. 19 , rio da cachoeira, Serra, col. Labo (MNRJ

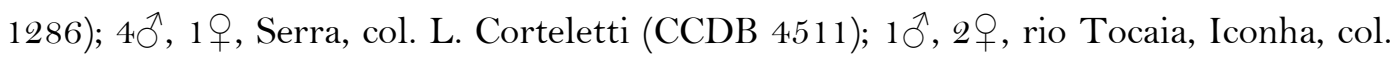
F. Carvalho et al. (CCDB 3987); 10̄, reserva de Santa Lúcia, Santa Tereza, col. A. Giupponi (MNRJ 192446).

Diagnose: Carapaça subquadrada. Margem ântero-lateral com 2 entalhes. Margem ântero-lateral da carapaça lisa. Margem póstero-lateral da carapaça lisa. Margem frontal reta e lisa. Margem orbital superior lisa. Margem orbital inferior com grânulos um pouco proeminente. Crista bucal lisa. Heteroquelia presente; quelípodos com um espinho rombudo presente na face interna do carpo; um pequeno espinho distal as vezes presente na face dorsal do mero. Antenas com 8 segmentos. Abdome do macho triangular com margem lateral reta. Gonópodo reto com ápice arredondado; abertura distal voltada para o lado mesial; constrição mediana quase ausente; bordo láteroproximal côncavo e levemente proeminente; bordo mésio-proximal reto; porção distal com bordo lateral e mesial reto.

Distribuição: Espírito Santo. 
Medidas: maior espécime analisado: CCDB (4511) - †, LC 31.22 mm.

Ecologia: Espécie de hábito noturno, sendo encontrada em cachoeiras, córregos, riachos, sob pedras, entre as raízes de vegetação marginal ou buracos marginais.

\section{Grupo V (Nordeste do Brasil): Trichodactylus cf. crassus}

Figuras $12 \mathrm{~A}, \mathrm{~B}, 16 \mathrm{~B}, \mathrm{E}$;

Material examinado: $\underline{\text { Alagoas. }} 19$, gruta do Pau Amarelo, fazenda Prata, São Miguel dos Campos, col. M. Décio \& M. Darte ( (MNRJ 1222); 19, Serra Branca, Murici, col. M. Décio \& M. Darte (MNRJ 1205); 1, gruta do Pau Amarelo, fazenda Prata, São Miguel dos Campos, col. M. Décio \& M. Darte (MNRJ 1169). Sergipe. 1 ㅇ, fazenda Boa União, riacho do Malhado, afluente do rio Piauí, col. O. Silva (MNRJ 1224); $2 \hat{\text {, }, ~} 1$, Estância, col. V. Lampert (CCDB 4528) Bahia. 10̂, rio Santana, Ilhéus, col. A. Almeida (CCDB 929); 5つ̂, 2 ㅇ, Ribeirão Serafim, Ilhéus, col. A. Almeida \& F.L.M. Mantelatto (CCDB 4529); 3ð̂, rio Santana, Ilhéus, col. A. Almeida (MZUESC 452); 10̂, 19 , CEPLAC, Ilhéus, col. Silva et al. (MZUSP 10784); 30̄, rio Vermelho, Elísio Medrado, col. E.A. Souza-Carvalho \& F.L. Carvalho (CCDB 3751); 40̂, reserva Jequitibá, rio do caranguejo, Elísio Medrado, col. S. Rocha, (CCDB 3938); 10ึ, Buerarema, col. F. Val (MZUSP 9698); 10̂, rio Paraguaçu, Castro Alves, col. S. Rocha (CCDB 4360); $1 \hat{\jmath}$, rio Una Mirim, estrada para Valença, col. S. Rocha (CCDB 4361); 10^, Jaguaribe, coletor desconhecido (MNRJ 17819); $3 \hat{\jmath}$, Floresta Azul, col. M. Trindade (CCDB 4513). 
Diagnose: Carapaça subcircular ou circular. Margem ântero-lateral da carapaça com um pequeno dente ou completamente lisa, sem entalhes. Margem póstero-lateral da carapaça lisa. Margem frontal em vista dorsal reta ou bilobada, lisa. Margem orbital superior lisa. Margem orbital inferior lisa ou com grânulos. Crista bucal lisa. Heteroquelia presente, mais acentuada nos machos; quelípodos com um espinho rombudo presente na face interna do carpo. Antenas com 10-12 segmentos. Abdome do macho triangular. Gonópodo reto com ápice simétrico e levemente anguloso; abertura distal voltada para o lado mesial; constrição mediana proeminente; bordo láteroproximal pouco proeminente; bordo mésio-proximal reto; porção distal com bordo lateral e mesial reto.

Distribuição: Bahia, Sergipe e Alagoas.

Ecologia: Espécie de hábito noturno, sendo encontrada em rios com corredeiras, córregos, riachos, sob pedras, na serrapilheira submersa ou em buracos marginais e raízes de vegetação marginal.

Medidas: maior espécime analisado: MNRJ (1224) - +, LC 38.18 mm.

Considerações: Espécimes jovens deste clado apresentam a carapaça recoberta por muitas cerdas, margem ântero-lateral com 1-2 dentes e abdome pode ser bem triangular. Além disso, vale ressaltar que as fêmeas coletadas em regiões do estado de Sergipe e Alagoas apresentam características morfológicas semelhantes aquela registrada na forma morfologicamente discrepante de Ilhéus (CCDB 4529). Os exemplares da Bahia presentes neste clado (espécimes de Elísio Medrado) são muito semelhante morfologicamente de acordo com a descrição de Trichodactylus crassus. 
Alguns exemplares da Bahia (Figuras 13 A; 16 C, F; 18 G) e Alagoas têm a carapaça com margem lateral provida de grânulos e alguns dentes, sendo completamente diferentes de outros locais (Almeida et al., 2008). Além disso, três espécimes deste clado (CCDB 4529, MNRJ 1222 e MNRJ 1224) merecem destaque, pois apresenta uma morfologia externa completamente diferente dos outros clados. A carapaça apresenta uma forma subquadrada; margem ântero-lateral provida de 3 dentes espiniformes, sendo os dentículos e grânulos localizados entre esses dentes; os dois primeiros dentes são mais próximos entre si e afastados do terceiro. Margem póstero-lateral é provida por 1 pequeno dente e grânulos diminutos; margem frontal provida de grânulos diminutos.

\section{Grupo VI (sul de São Paulo e sul do Brasil): Trichodactylus sp. 4}

Figuras: $13 \mathrm{~B}$.

Material examinado: $\underline{\text { São Paulo. }} 10^{\lambda}, 2$, Buri, col. S. Bueno et al. (MZUSP 15144);

1ठ̂, Rod 079 Km 161, Tapiraí (CCDB 2664); 3ð̂, Araçoiaba da Serra, col. S. Bueno et al. (CCDB 2666). Paraná. 10ึ, Serra Negra, Assungui, col. M. MayeR. (MHNCI 196); 1, Serra Negra, Assungui, col. M. Mayer (MHNCI 194); 1 , , rio Atuba, Curitiba, col. Z. Alexandre (MHNCI 558); 19, rio Atuba, Curitiba, col. Z. Alexandre (MHNCI 559); 1 , , rio Passaúna, Curitiba, col. M.H. Nogueira (MHNCI 440); 1울 rio Passaúna, Curitiba, col. M.H. Nogueira (MHNCI 441); 1仓̂, rio Mãe Catira, Morretes, col. Cury \& Wosiacki (MHNCI 1649); 19, rio Taquaral, Morretes, col. G. Hatschbach (MHNCI 155); 1 을 rio do Meio, Antonina, col. M. Segalla (MHNCI 594). Santa Catarina. $10^{\lambda}$, Camboriú, col. F.L. Carvalho(CCDB 4460); 10^, Blumenau, col. H. Boos, Jr. (UFRGS 3567); 10̂, Criciúma (INPA 1963); 10̂, Jaraguá do Sul, col. G.A. Souza-Filho (UFRGS 
2380). Rio Grande do Sul. 1ð̄, 1ㅇ, São José dos Ausentes, col. Gelain et al (INPA 1953); $1 \hat{\jmath}$, arroio do padre, Terra da Areia, col. W. Bruschi, Jr. (UFRGS 2233); 1 우, Osório, col. G. Bond-Buckup (UFRGS 2949); 19, Maquiné, col. F. Villela (UFRGS 3863).

Descrição: Carapaça circular, subquadrada ou elipsoide; margem lateral lisa ou carenada; margem ântero-lateral lisa ou com 1-2 entalhes; margem frontal quase reta e lisa. Margem orbital superior lisa. Margem orbital inferior com grânulos. Crista bucal liss. Heteroquelia mais acentuada nos machos; quelípodos com espinho rombudo e obtuso na face interna do carpo. Antena com 10-12 segmentos. Abdome do macho largo. Gonópodo reto com ápice levemente anguloso ou arredondado, as vezes truncado; abertura distal voltada para o lado mesial; constrição mediana bem pronunciada, algumas vezes voltada para a porção distal; bordo látero-proximal pouco proeminente; bordo mésio-proximal reto; porção distal bem curta com bordo lateral inflado e mesial levemente inflado.

Consideração: As fêmeas podem apresentar a margem frontal com alguns grânulos pequenos e espaçados; podem apresentar um pequeno espinho distal as vezes presente na face dorsal do mero. Apenas os indivíduos da população de Tapiraí (SP) apresentam a crista bucal com grânulos. O gonópodo de muitos exemplares apresenta a porção distal bem mais curta, ápice truncado e abdome com telso bem curto em relação a exemplares de outros clados (Figuras 14 F, G, H; 17 A, C e B, D; 18 I).

Distribuição: Sul de São Paulo ao sul do Brasil (Paraná, Santa Catarina e Rio Grande do Sul). 
Ecologia: Espécie de hábito noturno, sendo encontrada em rios, córregos, riachos, cachoeiras, sob pedras, na serrapilheira submersa.

Medidas: maior espécime analisado: UFRGS (3068) - ๆ, LC 32.24 mm. 
A

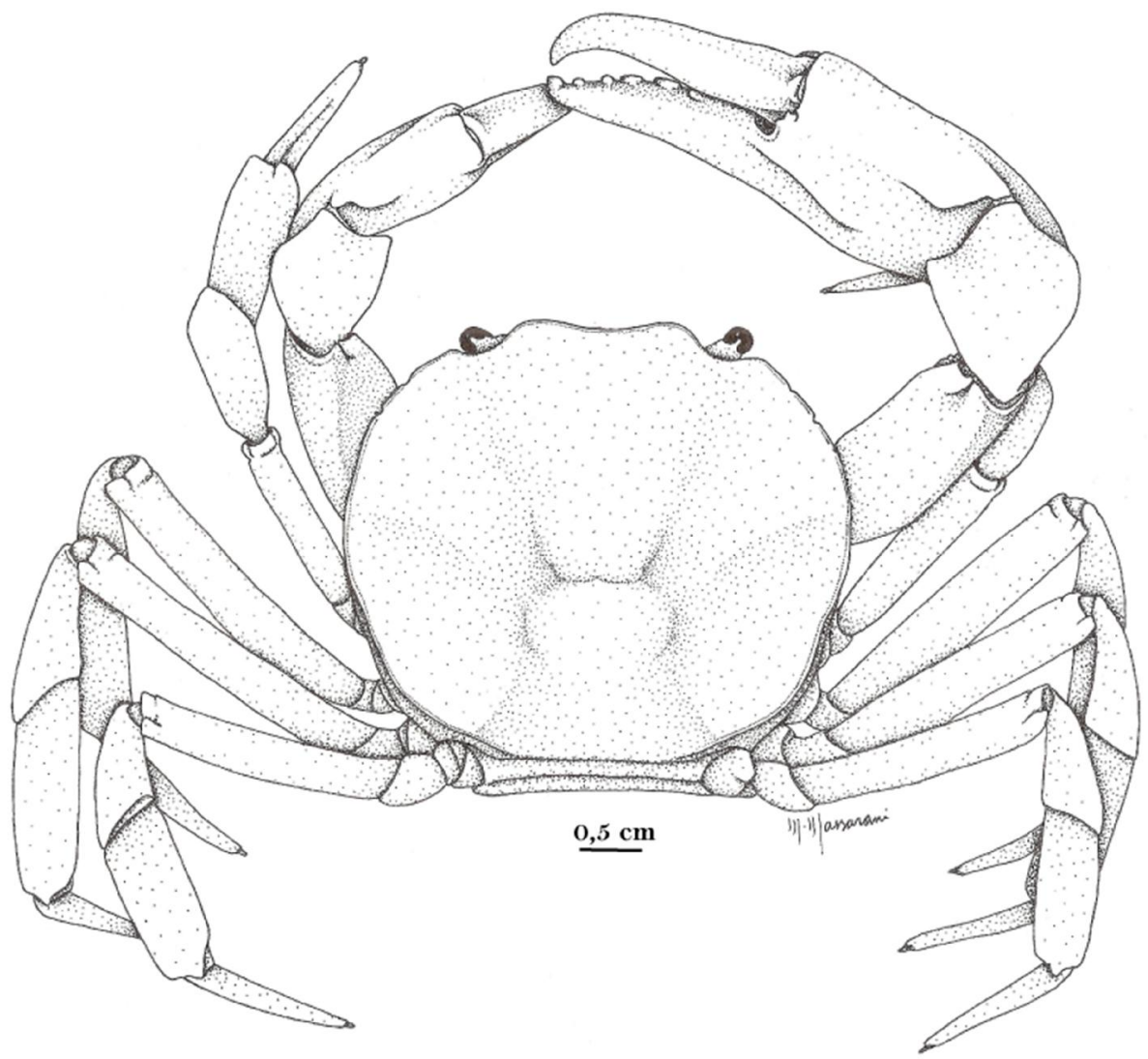

B

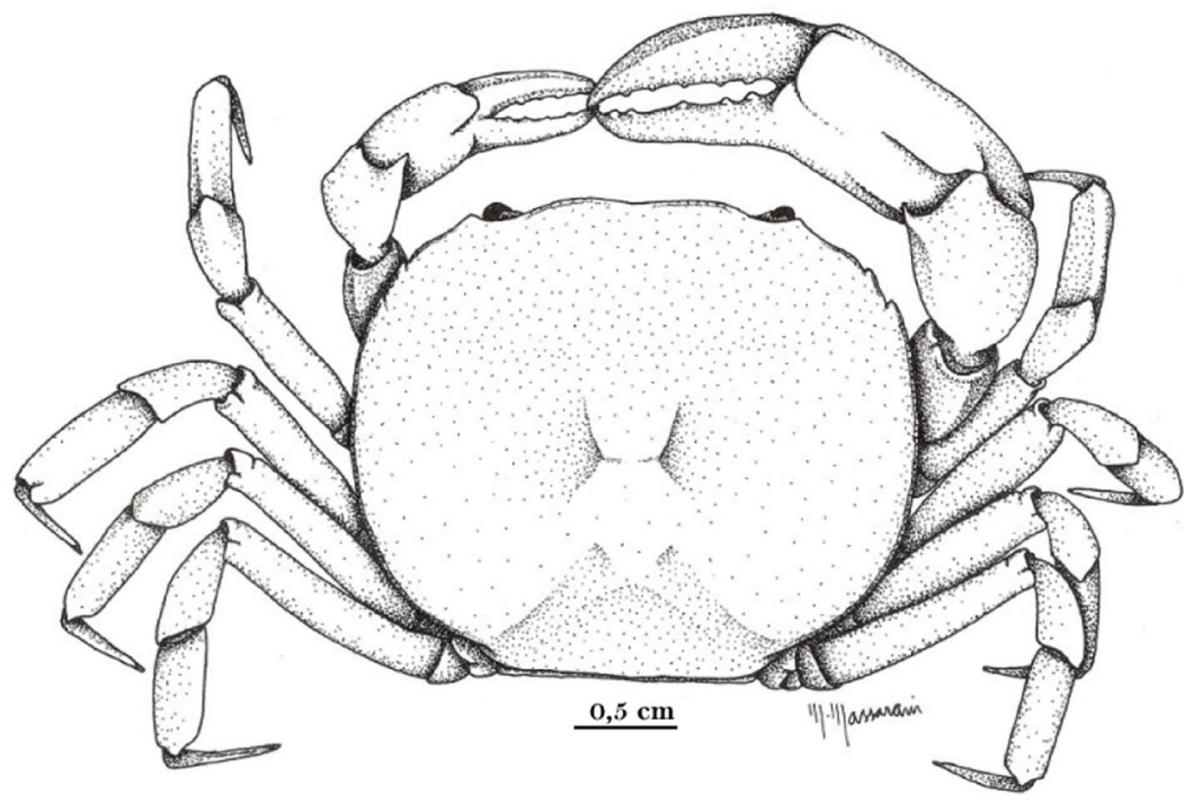

Figura 10. Vista dorsal de exemplares de A: T. fluviatilis sensu stricto, RJ: Rio de Janeiro, MNRJ 19149 (ð̊, LC 39.52 mm); B: T. fluviatilis, SP: Porto Ferreira, CCDB 4173 (ð̋, LC 26.94 $\mathrm{mm})$. 
A

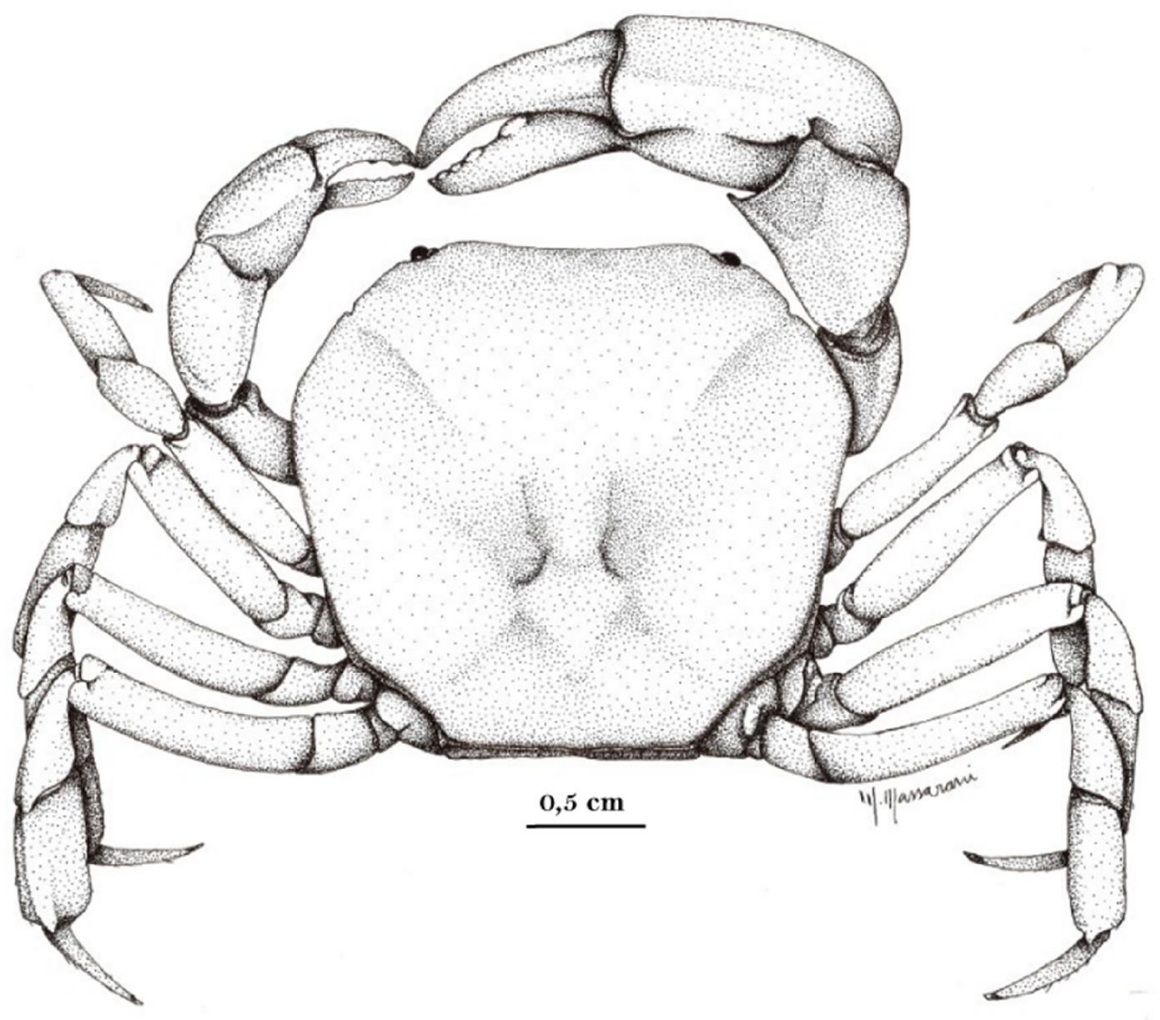

B

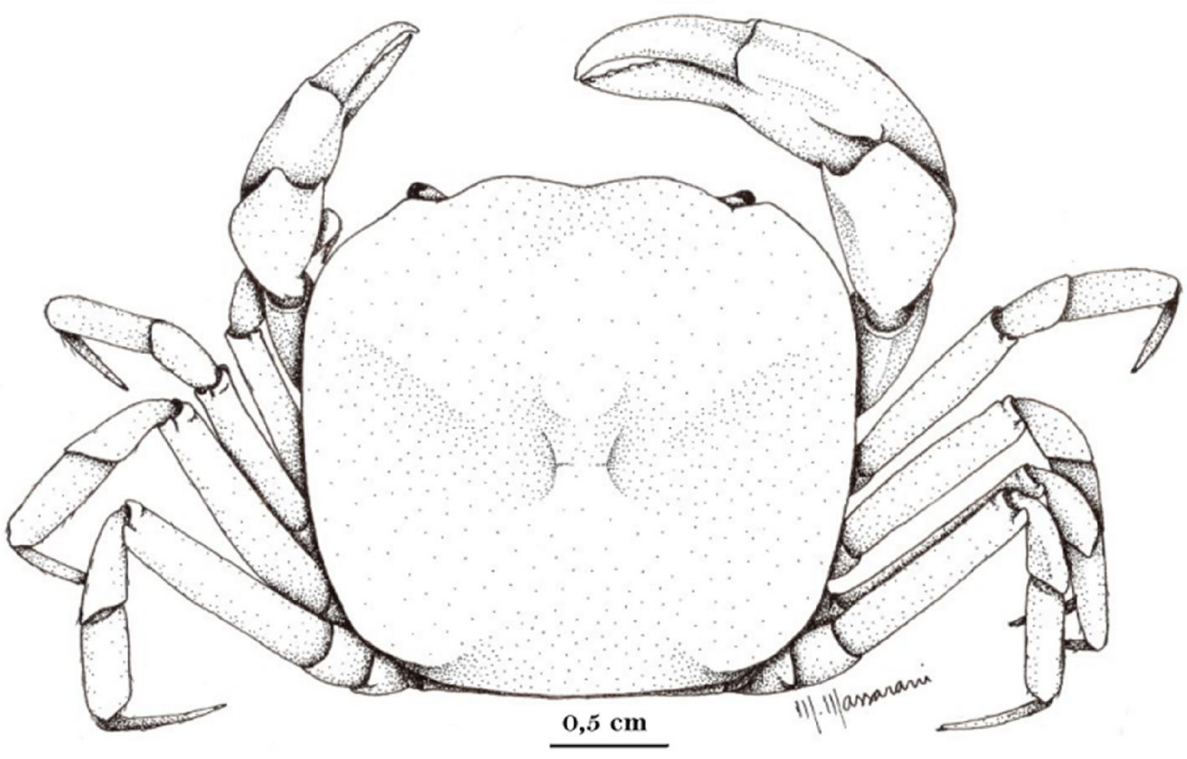

Figura 11. Vista dorsal de exemplares de A: Trichodactylus sp. 1, SP: Cananéia, CCDB 1772, (ð, LC 27.04 mm), B: Trichodactylus sp. 2, BA: Prado, CCDB 4186 (ð, LC 24.83 mm). 

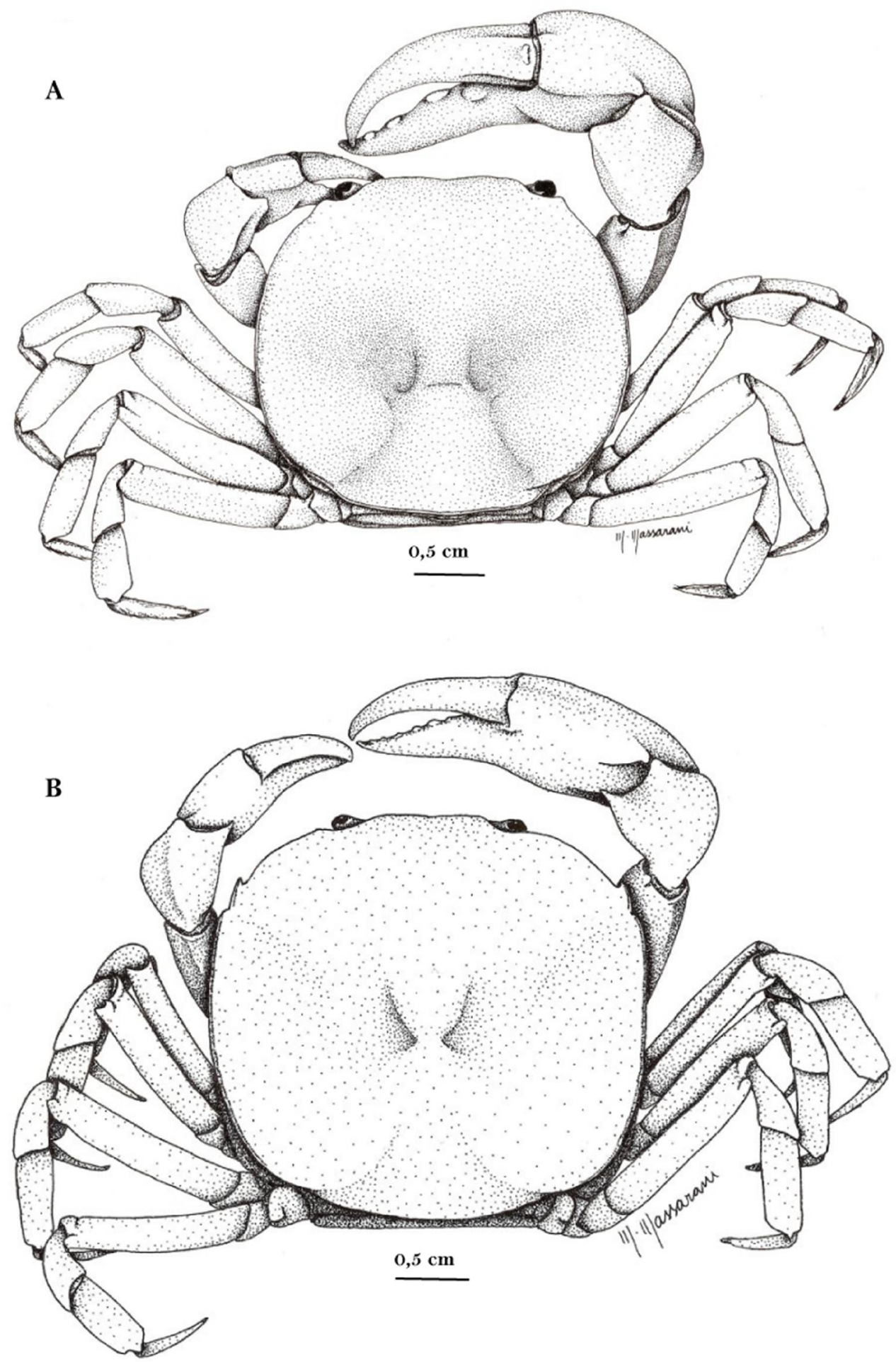

Figura 12. Vista dorsal de exemplares de A: Trichodactylus cf. crassus, BA: Elísio Medrado,

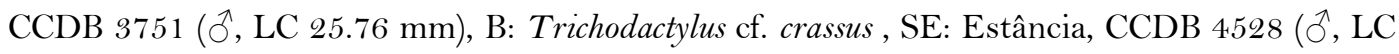
$24.41 \mathrm{~mm})$. 
A
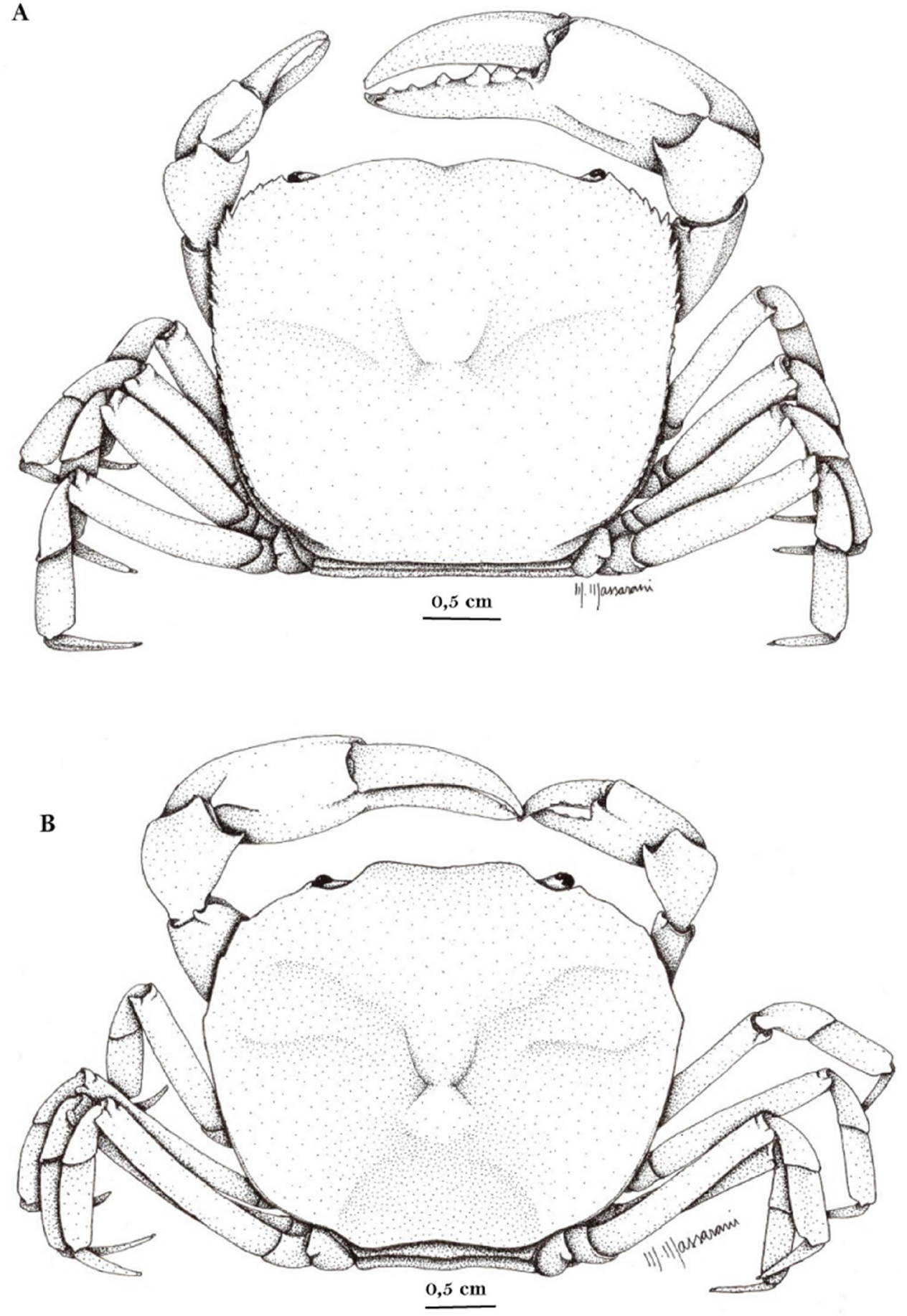

Figura 13. Vista dorsal de exemplares de A: Trichodactylus sp., BA: Ilhéus, CCDB 4529 (ð̂, LC 30.32 mm), B: Trichodactylus sp. 4, RS: São José dos Ausentes, INPA 1953 ( Ô, LC 29.94 mm). 
A

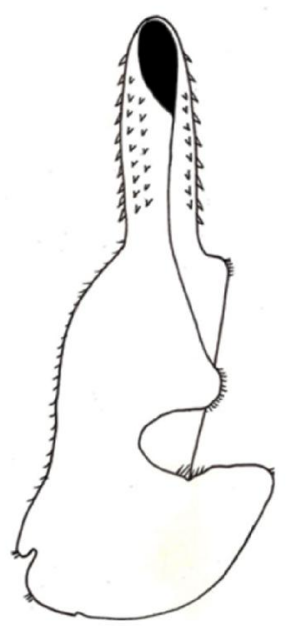

$3 \mathrm{~mm}$

E

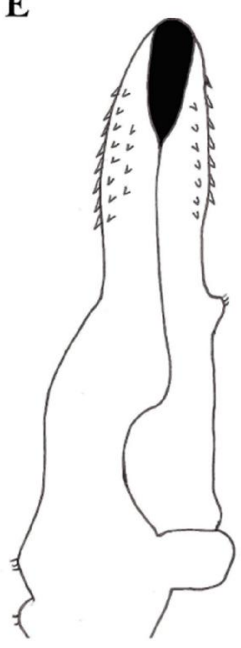

$3 \mathrm{~mm}$
B

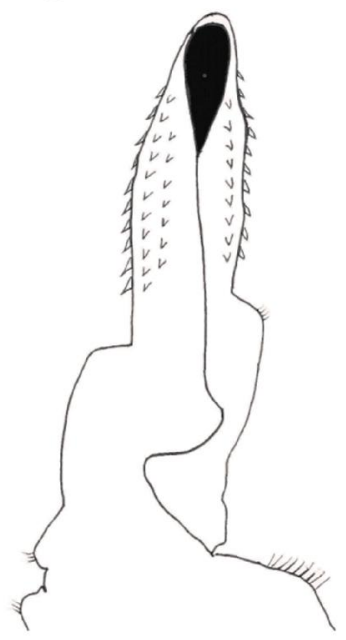

$3 \mathrm{~mm}$
C

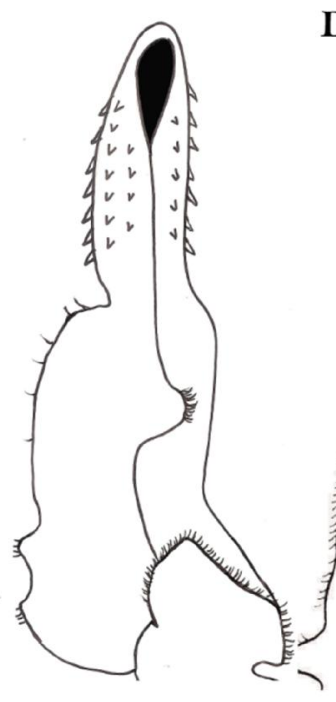

$3 \mathrm{~mm}$
D

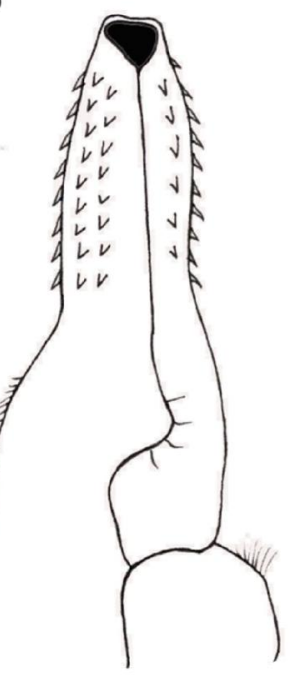

$3 \mathrm{~mm}$
G

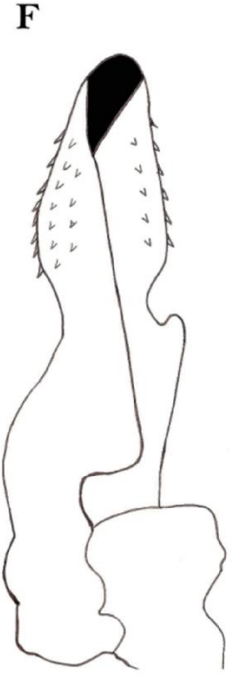

$3 \mathrm{~mm}$

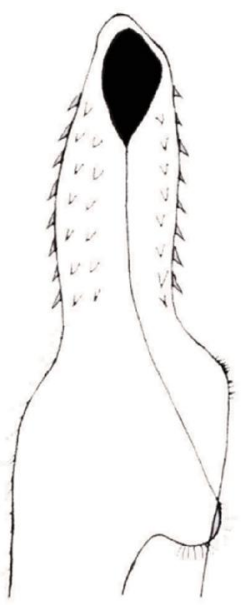

$3 \mathrm{~mm}$
H

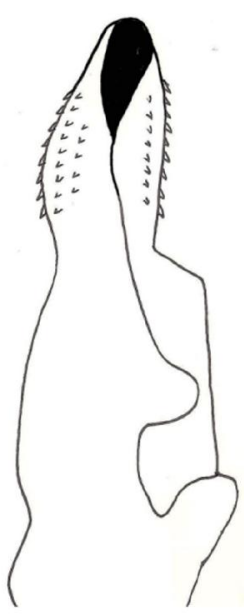

$3 \mathrm{~mm}$

Figura 14. Vista mésio-ventral do gonópodo 1 direito de espécimes do complexo Trichodactylus fluviatilis. A: T. fluviatilis sensu stricto (MNRJ 19149, ત̂, LC $39.52 \mathrm{~mm}$ ); B: Trichodactylus aff. fluviatilis (CCDB 4668, ô, LC $32.67 \mathrm{~mm}$ ); C: Trichodactylus sp. 1 (CCDB 3697, ô, LC 26.97 mm); D: Trichodactylus sp. 2 (CCDB 4186, Ô, LC 25.06 mm); E: Trichodactylus sp. 3 (CCDB 4511, О, LC $29.32 \mathrm{~mm}$ ); F: Trichodactylus sp. 4 (CCDB 2679, Оิ, LC $16.56 \mathrm{~mm}$ ); G: Trichodactylus sp. 4 (INPA 1963, đે, LC 31.59 mm); H: Trichodactylus sp. 4 (INPA 1951, ふै, LC $18.16 \mathrm{~mm})$. 

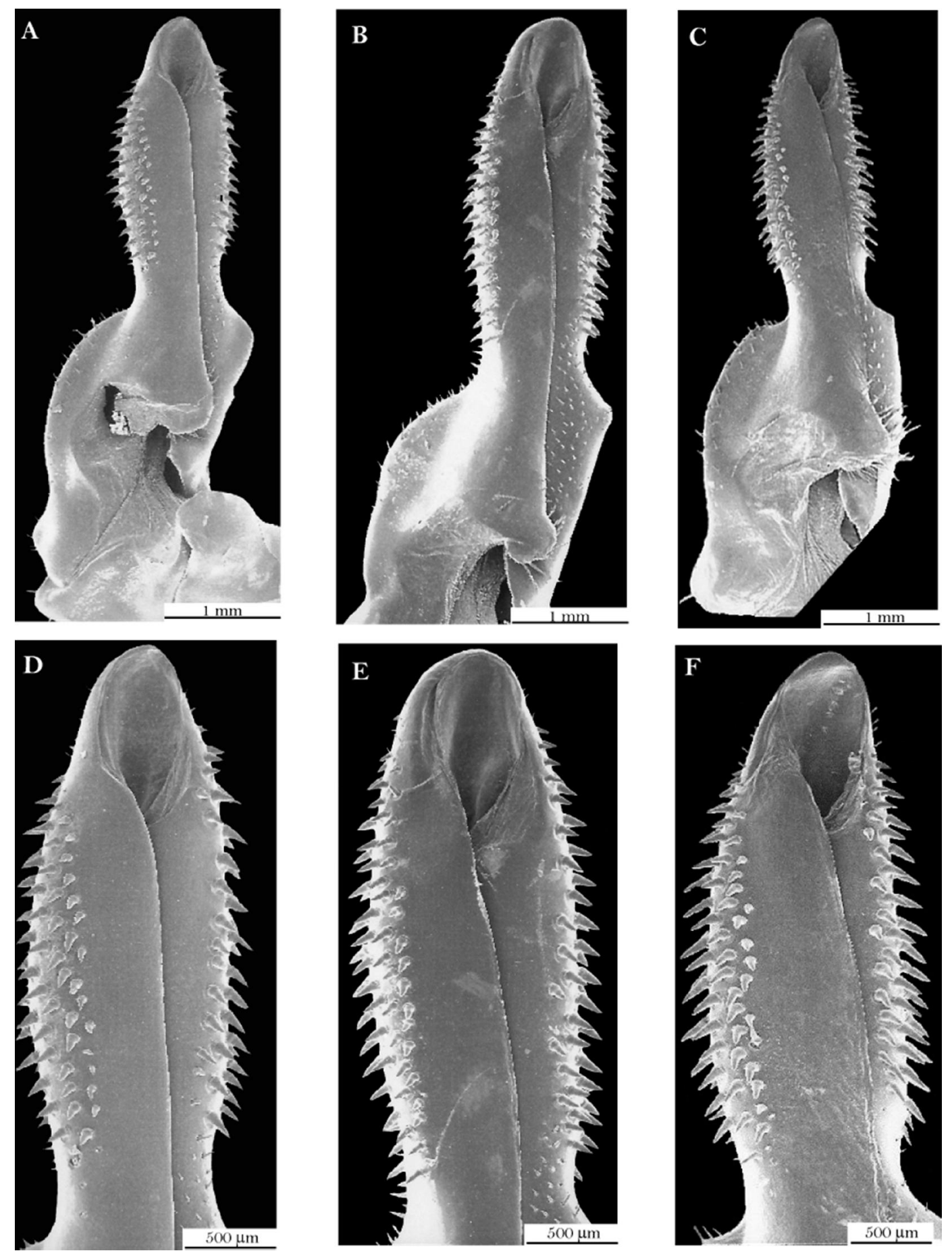

Figura 15. Imagem do gonópodo 1 direito (vista mésio-ventral) de espécimes do complexo $T$. fluviatilis feitas com Microscopia Eletrônica de Varredura. A, D: T. fluviatilis sensu stricto (CCDB 1574, LC 21.83 mm); B, E: T. fluviatilis sensu stricto (CCDB 2075, LC 26.94 mm); C, F: Trichodactylus sp. 1 (CCDB 1772, LC 27.26 mm). D, E e F: vista da porção distal do gonópodo. 

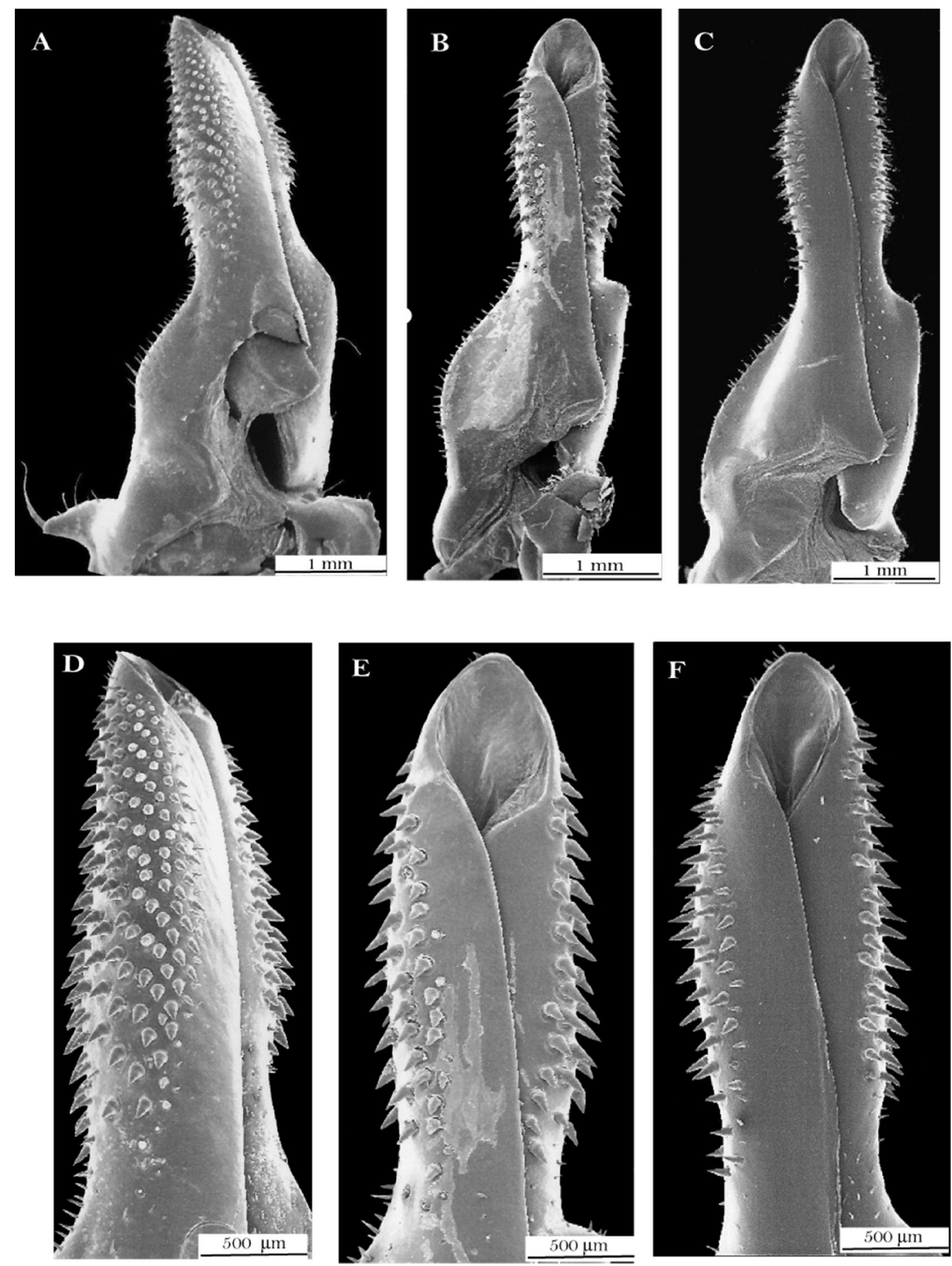

Figura 16. Imagem do gonópodo 1 direito (vista mésio-ventral) de espécimes do complexo $T$. fluviatilis feitas com Microscopia Eletrônica de Varredura. A, D: Trichodactylus sp. 2 (CCDB 4186, LC $25.06 \mathrm{~mm}$ ); B, E: Trichodactylus cf. crassus (CCDB 3751, LC $25.89 \mathrm{~mm}$ ); C, F: Trichodactylus sp. (CCDB 4529, LC 30.38 mm). D, E e F: vista da porção dista do gonópodo. 

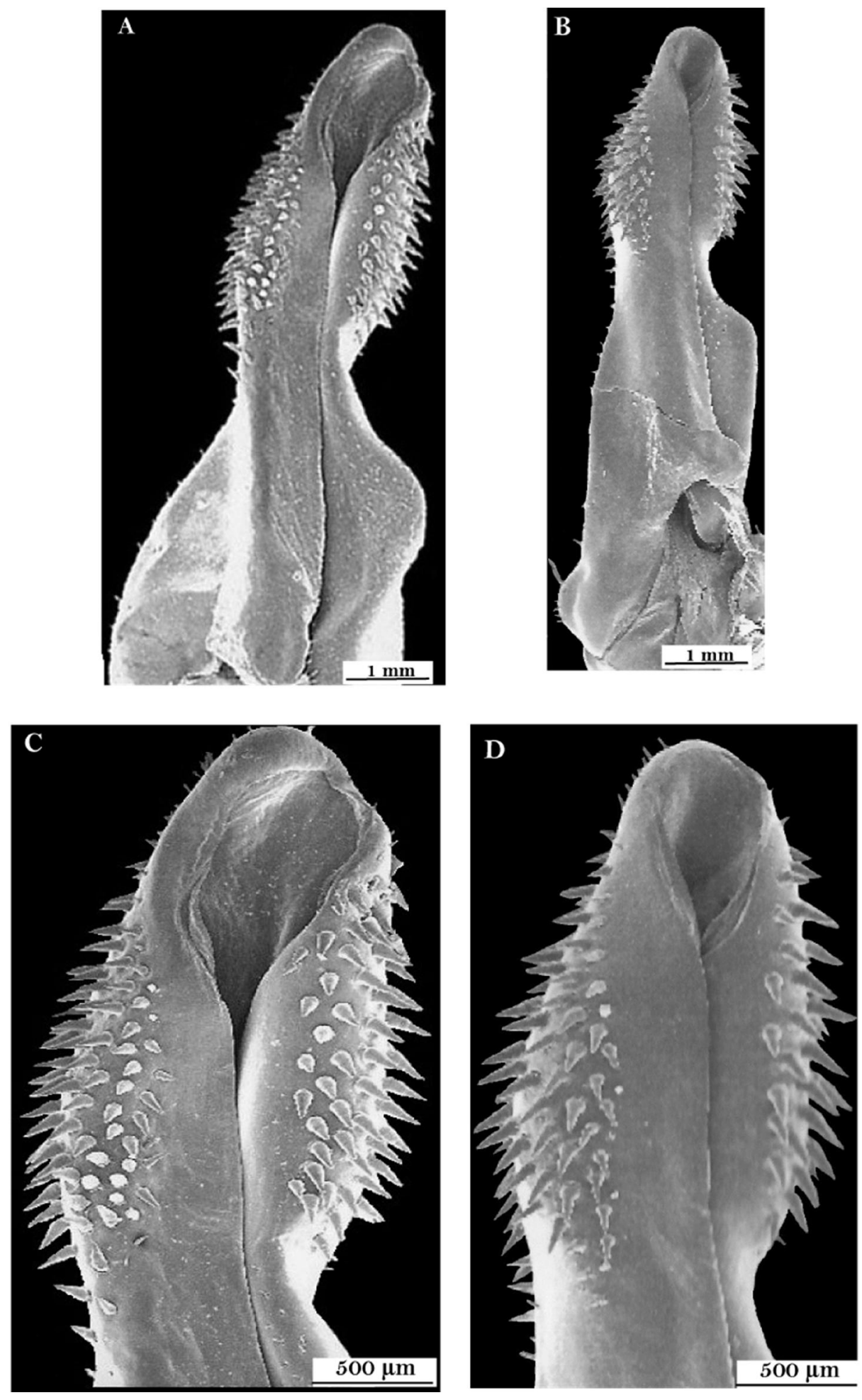

Figura 17. Imagem do gonópodo 1 direito (vista mésio-ventral) de espécimes do complexo $T$. fluviatilis feitas com Microscopia Eletrônica de Varredura. C: Trichodactylus sp. 4 (INPA 1963, LC $31.596 \mathrm{~mm}$ ); B, D: Trichodactylus sp. 4 (INPA 1951, LC $18.16 \mathrm{~mm}$ ). C e D: vista da porção distal do gonópodo. 

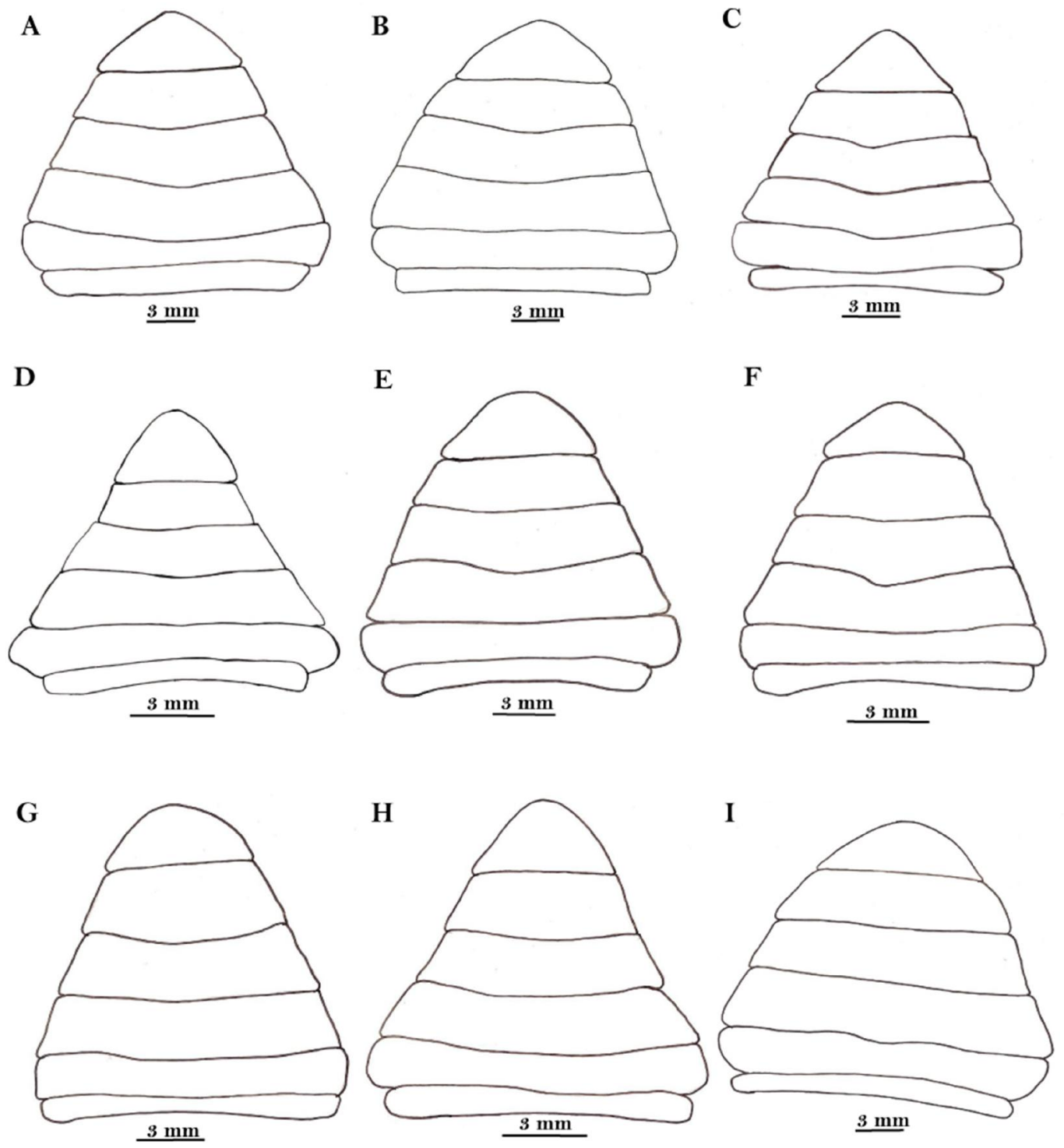

Figura 18. Abdome e telso de machos de espécimes do complexo Trichodactylus fluviatilis. A: $T$. fluviatilis sensu stricto (CCDB 1574, LC $21.83 \mathrm{~mm}$ ); B: Trichodactylus aff. fluviatilis (CCDB 4668, LC $32.67 \mathrm{~mm}$ ); C: Trichodactylus sp. 1 (CCDB 3697, LC $26.97 \mathrm{~mm}$ ); D: Trichodactylus sp. 2 (CCDB 4186, LC $25.06 \mathrm{~mm}$ ); E: Trichodactylus sp. 3 (CCDB 4511, LC $29.32 \mathrm{~mm}$ ); F: Trichodactylus cf. crassus (CCDB 3751, 2LC 5.89 mm); G: Trichodactylus sp. (CCDB 4529, LC $30.38 \mathrm{~mm}$ ); H: Trichodactylus cf. crassus (CCDB 4528, LC $24.13 \mathrm{~mm}$ ); I: Trichodactylus sp. 4 (INPA 1953, LC 29.94 mm). 


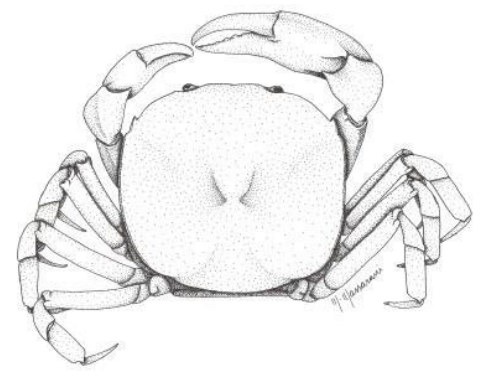

5. DISCUSS 


\subsection{Relações filogenéticas}

As populações de $T$. fluviatilis analisadas não constituem um grupo monofilético. Os resultados encontrados na análise molecular mostraram a formação de clados geneticamente distintos com altos valores de suporte para cada ramo e divergências genéticas consideráveis, deixando claro que a entidade taxonômica reconhecida morfologicamente como $T$. fluviatilis na verdade é um complexo formado por várias espécies, de acordo com o conceito filogenético de espécie (sensu Mishler \& Theriot, 2000). Esses clados pertencem a bacias hidrográficas distintas o que reforça a possibilidade de isolamento e consequente especiação.

As divergências genéticas encontradas foram consideravelmente elevadas e compatíveis com as diferenças já registradas entre espécies distintas de caranguejos de água doce e outros decápodos. Daniels et al. (2003), ao analisarem várias populações de Potamonautes clarus Gouws, Stewart \& Coke, 2000, relataram valores de divergência interespecíficos entre 0,2-10\% para o gene 16S. Espécies distintas de Potamonautes MacLeay, 1838 apresentaram divergências que variaram de 1,65 a 27,78\% para o gene 16S (Daniels et al, 2002). De acordo com Daniels et al. (2002), valores de divergências para o gene $16 \mathrm{~S}$ podem variar de $1 \%$ entre espécies crípticas a 23\% entre espécies de parentesco distantes pertencentes ao gênero Potamonautes.

Além da formação de clados geneticamente distintos, a parafilia encontrada nas populações reconhecidas morfologicamente como $T$. fluviatilis corrobora a existência de inconsistência taxonômica na espécie. Trichodactylus petropolitanus demonstrou-se uma espécie monofilética, e algumas vezes facilmente distinguida morfologicamente de T. fluviatilis. Entretanto, esta espécie foi alocada, com alto suporte, entre os clados da espécie reconhecida morfologicamente como $T$. fluviatilis em ambas as análises e para os genes $16 \mathrm{~S}$ e COI. 
Os espécimes presentes no clado II (Trichodactylus aff. fluviatilis) apresentam-se como o grupo mais próximo genética e morfologicamente de $T$. fluviatilis sensu stricto. Estes resultados podem estar relacionados aos eventos geológicos que ocorreram no rio Paraíba do Sul. Durante o Mioceno houve a captura fluvial da cabeceira do rio Tietê pelo rio Paraíba do Sul, ou seja, houve um desvio natural das águas do rio Tietê para o rio Paraíba do Sul (Oliveira, 2010). Esta captura fluvial pode ter provocado a dispersão desses caranguejos (Trichodactylus aff. fluviatilis) do Tietê para o Paraíba do Sul e isso pode explicar o fato deles ainda serem morfologicamente similares e geneticamente mais próximos do grupo sensu stricto.

O grupo morfológico no clado V (Trichodactylus cf. crassus), que apresentou uma divergência genética considerável, constitui-se em uma entidade distinta das demais populações analisadas, corroborando a hipótese de que estes animais podem ser considerados como T. crassus, espécie que já foi considerada sinônimo por Magalhães, 1991. Desta forma não haveria justificativa para considerar essa espécie como sinônimo de T. fluviatilis, sendo, portanto uma espécie válida, do ponto de vista morfológico e filogenético.

Os espécimes de Varzedo (BA) pertencentes a este clado formaram um subgrupo dentro do clado V (Trichodactylus cf. crassus). Embora essa localidade seja muito próxima a Elísio Medrado (BA), elas estão separadas por um divisor de águas, a Serra da Jibóia. Dessa forma, o fluxo gênico entre essas populações seria dificultado. Entretanto, são necessárias coletas em outros pontos dessa região para se avaliar a existência de fluxo gênico entre essas duas populações e outras regiões próximas, e assim considerar se estas correspondem ou não a espécies distintas.

Em relação aos indivíduos de Ilhéus com morfologia discrepante e que foram alocados nesse clado, será necessária a obtenção e análise de um maior numero de 
sequências genéticas para afirmar se a variação morfológica encontrada é uma resposta adaptativa ao ambiente em que vive ou se está relacionada a mudanças genotípicas.

A separação dessas populações de Trichodactylus em grupos geneticamente distintos encontra correspondência em áreas geográficas e bacias hidrográficas separadas. Esse isolamento com posterior divergência genética, pode ocorrer em populações naturais de crustáceos de água doce, uma vez que o ambiente terrestre pode representar uma barreira intransponível, impedindo dessa forma a dispersão e conectividade entre bacias (Carini \& Hughes, 2004; Vergamini, 2011). Além disso, a fragmentação de hábitats também pode reduzir uma possível dispersão em populações adjacentes, levando a um aumento da diferenciação genética (Carini \& Hughes, 2004).

Uma vez isoladas, essas populações podem acumular divergências genéticas de tal forma que não haverá mais fluxo gênico entre elas. Por sua vez, a inexistência de fluxo gênico acarretaria numa fixação de alelos e uma diferenciação genética entre as mesmas, podendo levar ao processo de especiação alopátrica com a formação de novas espécies com altos graus de endemismo ( $\mathrm{Ng} \&$ Yeo, 2007; Yeo et al., 2008)

O endemismo vem sendo reportado para vários grupos de crustáceos de água doce pertencentes às diferentes famílias. Países como China, Filipinas, Colômbia, México, Japão, dentre outros, possuem um grande número de espécies de caranguejos de água doce que são endêmicos. Dentre as famílias de caranguejos podemos citar como exemplo a Potamonautidae que apresenta muitas espécies endêmicas de determinadas regiões: Potamonautes brincki (Bott, 1960), P. granularis Daniels, Stewart \& Gibbons, 1998, P. parvispina Stewart, 1997a e P. clarus são endêmicas de diferentes sistemas de rios na África do Sul (Daniels et al., 2000; Cumberlidge \& Daniels, 2008). Além destes, cabe ressaltar que outros crustáceos dulcícolas como os aeglídeos apresentam também alto grau de endemismo, como por exemplo Aegla perobae Hebling 
\& Rodrigues, 1977, A. microphthalma Bond-Buckup \& Buckup, 1994 e Aegla franca Schmitt, 1942 que são registradas apenas para suas localidade-tipo (Bueno et al. 2007; Takano, 2011).

Estudos que trabalham com ferramentas moleculares estão reconhecendo muitas espécies crípticas em Decapoda e em outros grupos de animais (Daniels et al., 1998; Keenan et al., 1998; Schubart et al., 2001a, 2001b; Kitaura et al., 2002; Daniels et al., 2003; Liu et al., 2005; Schubart \& Koller, 2005; Pfenninger \& Schwenk, 2007; Lai et al., 2010; Negri et al., 2012). Daniels et al. (2000), ao analisar duas populações de Potamonautes brincki, descobriu dois grupos morfo e geneticamente distintos, sendo um deles considerado uma nova espécie. Ragioneiri et al. (2009), por meio de análises genéticas e morfométricas idenificaram o complexo Neosarmatium meinerti (De Man, 1887). Malay et al. (2009) descobriram uma espécie nova de Calcinus fuscus com clados geneticamente bem suportados.

Outros trabalhos recentes utilizaram a morfologia em conjunto com técnicas moleculares, relatando a descoberta de novas espécies, descrevendo a estrutura genética ou resolvendo problemas taxonômicos. Vergamini et al. (2011), ao analisar populações de Macrobrachium amazonicum Spence Bate, 1868, verificaram que as variações genéticas e morfológicas encontradas faziam parte da variabilidade populacional da espécie. Almeida et al. (2013) descreveram uma nova espécie de Alpheidae, Alpheus buckupi, morfologicamente similar a outras do mesmo grupo, mas claramente divergente do ponto de vista genético. Fransen (2013) descreveu uma nova espécie, Nippontonia christellae, com base em dados morfológicos e genéticos. Carvalho et al. (2013) encontraram a formação de dois grupos geneticamente distintos de Macrobrachium potiuna (Müller, 1880), sendo um deles uma possível espécie críptica. 
De forma análoga aos casos acima relatados, conclui-se que a espécie reconhecida morfologicamente como $T$. fluviatilis forma um complexo de espécies crípticas. Adicionalmente, este estudo também deixa claro que a utilização apenas da morfologia não permite realizar uma separação consistente das espécies nesse grupo, sendo de extrema importância a utilização também da ferramenta molecular no reconhecimento das mesmas. Portanto, é imperativo que uma nova nomenclatura associada à descrição dessas espécies seja proposta para acomodar taxonomicamente os grupos aqui relatados.

\subsection{Considerações taxonômicas}

As populações analisadas neste trabalho deixam claro que a espécie reconhecida morfologicamente como Trichodactylus fluviatilis apresenta uma alta plasticidade em muitos caracteres morfológicos. Desta maneira, o uso apenas da morfologia não é suficiente para delimitar com clareza o limite de algumas formas e identificar espécies crípticas. Os clados encontrados na análise filogenética molecular que confirmaram a presença de um conjunto de espécies crípticas também tiveram suporte morfológico.

A variação morfológica presente na espécie reconhecida morfologicamente como $T$. fluviatilis já foi relatada em alguns trabalhos anteriores por Göldi (1885, 1886), Rathbun (1906b), Mello (1967), Magalhães (1991), Almeida et al. (2008), porém todos inconclusivos e sem uma abordagem filogenética reunindo exemplares de várias localidades ao longo de sua distribuição, como feito no presente trabalho.

Mello (1967) e Magalhães (1991) em suas análises morfológicas com um número considerável de material proveniente de toda a distribuição da espécie observaram que a variabilidade de $T$. fluviatilis apresenta uma distribuição muito 
irregular e por isso consideraram mais conveniente tratar $T$. fluviatilis como um complexo de formas sem atribuir categorias taxonômicas inferiores, como subespécies ou variedades.

Almeida et al. (2008), analisaram indivíduos provenientes do sul da Bahia, encontraram duas formas (A e B) para T. fluviatilis. A forma A descrita por estes autores e também analisada no presente trabalho apresenta características morfológicas que a distingue de qualquer outro grupo morfológico. Muitos indivíduos juvenis da espécie reconhecida morfologicamente como $T$. fluviatilis geralmente apresentam características morfológicas que ao longo de sua ontogenia vão sendo perdidas, podem se tornar reduzidas ou até mesmo mudar a sua forma quando os indivíduos se tornam adultos. Entretanto, os indivíduos juvenis dessa forma apresentaram as mesmas características dos adultos, indicando que as variações encontradas nesse grupo são consistentes durante todo o desenvolvimento do indivíduo.

Algumas dessas características morfológicas que estes espécimes apresentam como a forma, tamanho e posição dos dentes na margem ântero-lateral da carapaça, e a fronte acentuadamente bilobada, são semelhantes a outras espécies do gênero, como $T$. dentatus e T. petropolitanus. Segundo Magalhães (1991), essas três espécies são semelhantes morfologicamente e, devido a sua alta variabilidade, uma distinção segura entre elas se torna difícil em alguns casos. Todavia, T. dentatus e T. petropolitanus, na maioria das vezes, podem ser facilmente distinguidos desta forma discrepante de $T$. fluviatilis encontrada em Ilhéus e dos demais grupos morfológicos do complexo $T$. fluviatilis pelo número e forma dos dentes na margem ântero-lateral da carapaça.

Considerando os diversos grupos morfológicos encontrados, é imperativo que se defina qual é a entidade que representa T. fluviatilis sensu stricto. Embora Latreille 
(1828) não faça nenhum tipo de citação com relação à localidade-tipo (mencionando apenas Brasil), e quantos animais foram analisados na sua descrição, levanta-se a possibilidade desta ser localizada no Rio de Janeiro. Esta possibilidade, também indicada por Bott (1969), possui suporte nas várias expedições científicas que ocorreram no Brasil no século XIX, contemplando o Rio de Janeiro e outras cidades litorâneas. Ademais, a localidade-tipo de $T$. petropolitanus, espécie próxima a $T$. fluviatilis, é na região de Petrópolis, Rio de Janeiro. O grupo morfológico que ocorre nessa região apresenta características morfológicas mais próximas à descrição original de Latreille (1828), embora essa descrição seja superficial. Dessa forma, este grupo juntamente com demais indivíduos que ocorrem na parte litorânea de São Paulo, foi denominado de T. fluviatilis sensu stricto. Porém, são necessárias coletas adicionais no Rio de Janeiro, principalmente na parte litorânea, para se aumentar a confiabilidade e representatividade dos dados.

O grupo formado por $T$. fluviatilis sensu stricto apresenta uma alta plasticidade em muitos caracteres morfológicos. Geralmente, os caracteres diagnósticos que mais sofrem variação são: forma da carapaça, presença de entalhes ou dentes e forma do gonópodo. Mesmo com a sobreposição de muitos caracteres morfológicos analisados, foi possível encontrar uma combinação de caracteres que delimitam este e os demais grupos.

A região da bacia do Paraíba do Sul, que engloba alguns municípios do Rio de Janeiro, Minas Gerais e Espírito Santo possui indivíduos que apresenta a forma mais similar a T. fluviatilis sensu stricto. Cabe ressaltar que o espécime de Bocaina de Minas (Minas Gerais) foi coletado a $1.010 \mathrm{~m}$ de altitude, sendo este o registro altitudinal mais elevado para esta espécie. Essas semelhanças morfológicas entre esses grupos podem 
estar relacionadas a eventos geológicos que ocorreram nessa região, como a captura do rio Tietê pelo Paraíba do Sul.

O grupo III (Trichodactylus sp. 2) constituído por animais provenientes do extremo sul da Bahia (regiões de Prado e Porto Seguro), formaram um grupo morfologicamente distinto dos demais indivíduos desse estado e de outras localidades do Brasil. Esta morfologia diferenciada pode estar associada aos diferentes processos geológicos, como por exemplo a Formação Barreiras (Lima et al., 2006). Esta formação constitui depósitos sedimentares de origem predominantemente continental, mas também marinha, que se estende desde a região Amazônica (região costeira) até o Rio de Janeiro (Lima et al., 2006; Nunes et al., 2011). O extremo sul da Bahia é considerado uma área de domínio dessa formação, apresentando relevo tabulares característicos e com amplo domínio de argissolos, sendo considerado, portanto um ambiente diferenciado (Lima et al., 2006; Oliveira, 2007). Portanto, durante a formação do grupo Barreiras nessa região pode ter ocorrido um isolamento desta população de caranguejo, o que pode ter levado a divergências morfológicas e genéticas.

O extremo sul da Bahia é uma região com expressiva complexidade de sistemas hídricos, sendo intercortada por várias bacias hidrográficas de pequeno e médio porte (Sarmento-Soares et al., 2009). Essa região apresenta uma vasta riqueza hídrica, porém é pouco estudada. Estudos realizados com a fauna ictiológica vêm mostrando a grande diversidade e endemismo de peixes nessa região (Sarmento-Soares et al., 2009).

Os espécimes desse grupo (Trichodactylus sp. 2) foram coletados próximos à porção inferior do rio Jucuruçu. Esses caranguejos apresentam características morfológicas diferentes e que os separam de outros grupos, como por exemplo, a forma do gonópodo. Fica claro, portanto, que os espécimes desse grupo constituem uma espécie distinta e endêmica desta região do extremo sul da Bahia. O registro de novas 
espécies nessa região também foi relatado para peixes do gênero Characidium, Parotocinclus Eigenmann \& Eigenmann, 1889 (Sarmento-Soares et al., 2009), demonstrando que eventos geológicos podem estar propiciando a especiação de populações de alguns grupos de organismos nessa região.

O clado V (Trichodactylus cf. crassus) formado por espécimes de diferentes bacias hidrográficas na Bahia, Sergipe e Alagoas estão alguns indivíduos bem semelhantes morfologicamente com T. crassus A. Milne-Edwards, 1869. Essa semelhança está relacionada à forma da carapaça, que é mais circular quando comparada aos demais grupos morfológicos, e à margem ântero-lateral da carapaça, que apresenta um dente espiniforme. Magalhães (1991) ao analisar espécimes de T.fluviatilis da Bahia também encontrou semelhança com $T$. crassus quanto à morfologia da carapaça, que apresentou características intermediárias entre a forma orbicular e a forma crassus, sendo ambas muito semelhantes entre si. Bott (1970) sugeriu que T. crassus poderia ser considerado sinônimo de T. fluviatilis. Magalhães (1991) também considerou esta espécie como sinônimo de $T$. fluviatilis, porém trabalhos recentes consideraram T. crassus como espécie válida (Magalhães \& Türkay, 1996a; Ng et al., 2008). Em função da similaridade morfológica entre esse clado $\mathrm{V}$ e a forma $T$. crassus, e que a localidade-tipo desta última é a Bahia (A. Milne-Edwards, 1869), provavelmente arredores de Salvador, pode-se inferir que este grupo corresponde à espécie T. crassus. Entretanto, a análise do material-tipo desta espécie e a ampliação de amostragem na região é necessária para uma atribuição segura do nome T. crassus para esse grupo.

Os espécimes pertencentes ao clado VI (Trichodactylus sp. 4), embora oriundos de áreas geográficas distintas, foram considerados pertencentes ao mesmo grupo taxonômico devido à semelhança na morfologia do gonópodo que os separam dos demais grupos. Os espécimes deste clado merecem destaque em relação ao gonópodo 
que apresenta a porção distal curta, sendo este caráter claramente distinto em relação aos demais grupos analisados.

Fica claro, portanto, que para alguns grupos (Trichodactylus sp. 2 e Trichodactylus sp. 4) do complexo T. fluviatilis o gonópodo é o caráter mais informativo e pode ser utilizado na separação dos mesmos, enquanto que para outros grupos, que apresentam sobreposição de alguns caracteres como o número de entalhes ou dentes na margem ântero lateral da carapaça, é aconselhável a utilização de um conjunto de características para definir cada grupo morfológico.

As variações encontradas na morfologia de fluviatilis sensu stricto e grupos afins foram observadas em espécimes que habitam o mesmo local ou em populações que habitam diferentes regiões geográficas e ambientes distintos. Outros grupos de crustáceos de água doce também apresentaram variações entre diferentes populações analisadas; este é o caso do caranguejo Potamonautes brincki, do camarão da família Atyidae, Atyaephyra desmarestii (Millet, 1831), do palaemonídeo Palaemonetes antennarius (H. Milne Edwards, 1837) e Aegla plana Buckup \& Rossi, 1977 (Stewart, 1997b; Daniels et al., 2000; Anastasiadou \& Leonardos, 2008; Anastasiadou et al., 2009; Hepp et al., 2012).

A variação morfológica encontrada nessas populações de caranguejos e outros crustáceos de água doce pode ser reflexo de diferenças genéticas entre os indivíduos (polimorfismos genéticos) ou influenciada por diferentes pressões seletivas como dieta, comportamento, temperatura, desenvolvimento, dentre outros fatores ocasionados por mudanças ambientais (Wimberger, 1992; Schwander \& Leimar; 2011; Hepp et al., 2012). A heterogeneidade de cada ambiente pode provocar uma radiação adaptativa e levar ao processo de especiação de uma determinada população (Hepp et al., 2012). Além disso, se a variação morfológica vier acompanhada de isolamento geográfico, 
pode ocorrer uma ruptura do fluxo gênico, sendo este o primeiro passo para que ocorra especiação (Irwin et al., 2001, 2005; Hepp et al., 2012).

Desta forma, conclui-se que a expressiva plasticidade morfológica em $T$. fluviatilis descrita em trabalhos anteriores não pode ser atribuída unicamente à variabilidade populacional deste táxon, mas também à presença de um conjunto de espécies morfologicamente similares, como reveladas nas relações filogenéticas inferidas com base nos dados moleculares. 


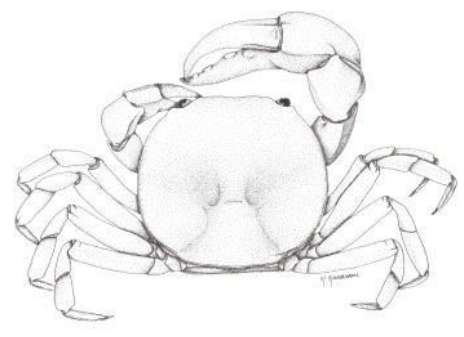

6. CONCLUSÕES 
Diante dos resultados encontrados em que as populações da espécie reconhecida morfologicamente como T. fluviatilis não constituem um grupo monofilético, sendo composta por um complexo de espécies.

A maioria dos caracteres diagnósticos descritos para a espécie $T$. fluviatilis não é informativa devido à sua considerável variabilidade. Dessa forma, a proposição de novos táxons no grupo deve ser baseada em uma combinação de características morfológicas em conjunto com outras ferramentas, como a molecular.

Conclui-se que a existência de um complexo de espécies no que se reconhecia até o momento como $T$. fluviatilis demonstra que a fauna de caranguejos de água doce no Brasil está subestimada e que mais estudos envolvendo o uso de técnicas moleculares devem ser realizados com urgência para evitar o desaparecimento de espécies que ainda nem foram descritas e estudadas. 


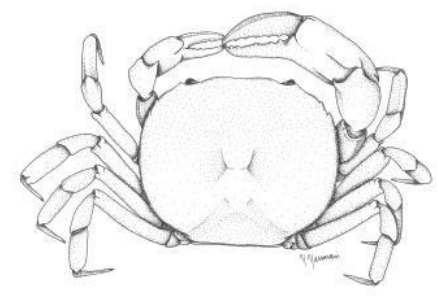

7.REFERÊNCLAS 
ALMEIDA, A.L.; COELHO, A.P.; LUZ, J.P.; SANTOS, J.T. \& FERRAZ, N.R. 2008. Decapod crustaceans in fresh waters of southeastern Bahia, Brazil. Revista Biología Tropical, 56(3): 1225-1254.

ALMEIDA, A.; TEROSSI, M.; ARAÚJO-SILVA, C.L. \& MANTELATTO, F.L. 2013. Description of Alpheus buckupi spec. nov., a new amphi-Atlantic snapping shrimp (Caridea: Alpheidae), based on morphological and molecular data. Zootaxa, 3652(4): 437-452.

ANASTASIADOU, C. \& LEONARDOS, I.D. 2008. Morphological variation among populations of Atyaephyra desmarestii (Decapoda: Caridea: Atyidae) from freshwater habitats of northwestern Greece. Journal of Crustacean Biology, 28(2): 240-247.

ANASTASIADOU, C.; LIASKO, R. \& LEONARDOS, I.D. 2009. Biometric analysis of lacustrine and riverine populations of Palaemonetes antennarius (H. Milne Edwards, 1837) (Crustacea, Decapoda, Palaemonidae) from northwestern Greece. Limnologica, 39: 244-254.

ANGER, K. 1995. The conquest of freshwater and land by marine crabs: adaptations in life-history patterns and larval bioenergetics. Journal of Experimental Marine Biology and Ecology, 193: 119-145.

BOTT, R. 1969. Die Süsswasserkrabben Süd-Amerikas und ihre Stammesgeschichte: eine revision der Trichodactylidae und der Pseudothelphusidae östlich der Anden (Crustacea, Decapoda). Abhandlungen der senckenbergischen naturforschenden gesellschaft, 518: 1-94.

BOTT, R. 1970. Betrachtungen über die Entwicklungsgeschichte und Verbreitung der Süßwasserkrabben nach der Sammlung des Naturhistorischen Museums in Genf/Schweiz. Revue Suisse de Zoologie, 77: 327-344. 
BUENO, S.L.S.; SHIMIZU, R.M. \& ROCHA, S.S. 2007. Estimating the population size of Aegla franca (Decapoda, Anomura, Aeglidae) by mark-recapture technique from an isolated section of Barro Preto stream, county of Claraval, state of Minas Gerais, southeastern Brazil. Journal of Crustacean Biology 27: 553-559.

CARINI, G. \& HUGHES, J.M. 2004. Population structure of Macrobrachium australiense (Decapoda: Palaemonidae) in Western Queensland, Australia: the role of contemporary and historical processes. Heredity, 93(4): 350-363.

CARVAlHO, F.; PILEGGI, L.G. \& MANTELATTO, F.L. 2013. Molecular data raise the possibility of cryptic species in the Brazilian endemic prawn Macrobrachium potiuna (Decapoda, Palaemonidae). Latin American Journal of Aquatic Research, , 41(4): 707-717.

CUMBERLIDGE, N. 1999. The freshwater crabs of West Africa: Family Potamonautidae. Paris: Institut de Recherche pour le De'veloppement, Collection Faune et Flore Tropicales. 382 p.

CUMBERLIDGE, N. \& DANIELS, S.R. 2008. A conservation assessment of the freshwater crabs of southern Africa (Brachyura: Potamonautidae). African Journal of Ecology, 46: 74-79.

CUMBERLIDGE, N. \& NG, P.K.L. 2009. Systematics, evolution, and biogeography of freshwater crabs. In: MARTIN, J.W.; CRANDALL, K.A. \& FELDER, D.L. (eds.). Decapod Crustacean Phylogenetics. Taylor and Francis/CRC Press, Boca Raton. Crustacean Issues, 18: 491-508.

CUMBERlidGe, N.; NG, P.; YEO, D.C.J.B.; MAGAlHÃES, C.; CAMPOS, M.R; ALVAREZ, F.; NARUSE, T.; DANIELS, S.R.; ESSER, L.R.; ATTIPOE, F.Y.K; CLOTILDE-BA, F.L; DARWALL, W.; MCIVOR, A.; JONATHAN E.M.; BAILLIE, J.E.M.; COLLEN, B. \& RAM, M. 2009. Freshwater crabs and 
the biodiversity crisis: Importance, threats, status, and conservation challenges. Biological Conservation, 142: 1665-1673.

DANIELS, S.R. 2003. Examining the genetic structure among populations of the common cape river crab Potamonautes perlatus from river systems in South Africa reveals hydrographic boundaries. Journal of Crustacean Biology, 23: 936-950.

DANIELS，S.R.; CUMBERLIDGE，N.; PÉREZ-LOSADA， M.; MARIJNISSEN, S.A.E. \& CRANDALL, K.A. 2006. Evolution of Afrotropical freshwater crab lineages obscured by morphological convergence. Molecular Phylogenetics and Evolution, 40: 227-235.

DANIELS, S.R.; GOUWS, G.; STEWART, B.A. \& COKE, M. 2003. Molecular and morphometric data demonstrate the presence of cryptic lineages among freshwater crabs (Decapoda: Potamonautidae: Potamonautes) from the Drakensberg Mountains, South Africa. Biological Journal of the Linnean Society, 78: 129-147.

DANIELS, S.R.; STEWART, B.A. \& BURMEISTER, L. 2000. Geographic patterns of genetic and morphological divergence amongst populations of a river crab (Decapoda, Potamonautidae) with the description of a new species from mountain streams in the Western Cape, South Africa. Zoologica Scripta, 30(3): 181-197.

DANIELS, S.R.; STEWART, B.A \& GIBBONS, M.J. 1998. Potamonautes granularis sp. nov. (Brachyura, Potamonautidae), a new cryptic species of river crab from the Olifants River System, South Africa. Crustaceana, 71(8): 885-903.

DANIELS, S.R.; STEWART, B.A.; GOUWS, G.; CUNNINGHAM, M. \& MATTHEE, C.A. 2002. Phylogenetic relationships of the southern African freshwater crab fauna (Decapoda: Potamonautidae: Potamonautes) derived from 
multiple data sets reveal biogeographic patterning. Molecular Phylogenetic and Evolution, 25: 511-523.

DARRIBA, D.; TABOADA, G.L; DOALlO, R. \& POSADA D. 2012. jModelTest 2: more models, new heuristics and parallel computing. Nature Methods, 9(8): 772.

DARWIN, C. 1859. On The Origin of Species. London: John Murray, 502 p.

DUDGEON, D. 2010. Prospects for sustaining freshwater biodiversity in the 21 st century: linking ecosystem structure and function. Current Opinion in Environmental Sustainability, 2: 422-430.

EYDOUX, F. \& SOULEYET, L.F.A. 1842. Crustacés. In: VAILLANT, A.N. Voyage autour du monde exécuté pendant les années 1836 et 1837 sur la corvette la Bonite. Paris: Arthus Bertrand, 2: 219-250.

FANG, F.; SUN, H.; ZHAO, Q.; LIN, C.; SUN, Y.; GAO, W.; XU, J.; ZHOU, J.; GE, F. \& LIU, N. 2013. Patterns of diversity, areas of endemism, and multiple glacial refuges for freshwater crabs of the genus Sinopotamon in China (Decapoda: Brachyura: Potamidae). PLoS ONE 8(1):e53143. doi:10.1371/journal.pone.0053143.

FELSENSTEIN, J. 1985. Confidence limits on phylogenies: an approach using the bootstrap. Evolution, 39: 783-791.

FOLMER, O.; BLACK, M.; LUTZ, R. \& VRIJENHOEK, R. 1994. DNA primers for amplification of mitochondrial cytochrome c oxidase subunit I from diverse metazoan invertebrates. Molecular Marine Biology and Biotechnology, 3(5): 294-299.

FRANCISCO, A.K. \& GALETTI JUNIOR, P.M 2005. Genetic distance between broodstocks of the marine shrimp Litopenaeus vannamei (Decapoda, Penaeidae) by mtDNA analyses. Genetics and Molecular Biology, 28: 258-261. 
FRANSEN, C.H.J.M. 2013. A new species of the sponge-associated pontoniine shrimp genus Nippontonia Bruce \& Bauer, 1997 (Decapoda, Caridea, Palaemonidae) from Sabah, Malaysia. Zootaxa, 3694(4): 343-357.

FUTUYMA, D.J. 1992. Biologia evolutiva. 2. ed. Ribeirão Preto: Sociedade Brasileira de Genética/CNPq. 646 p.

GELlER J.B; WALTON, E.D; GROSHOLZ E.D. \& RUIZ, G.M. 1997. Cryptic invasion of the crab Carcinus detected by molecular phylogeography. Molecular Ecology, 6: 901-906.

GÖLDI, E.A. 1885. Studien über neue und wenig bekannte Podophthalmen Brasiliens. Vorläufige Notizen Zoologischer Anzeiger, 8: 662-663.

GÖLDI, E.A. 1886. Studien über neue und weniger bekannte Podophthalmen Brasiliens. Archiv für Naturgeschichte, 52: 19-46.

GOMIDES, S.C.; NOVELli, I.A.; SANTOS, A.O.; BRUGIOLO, S.S.S. \& SOUSA, B.M. 2009. Novo registro altitudinal de Trichodactylus fluviatilis (Latreille, 1828) (Decapoda, Trichodactylidae) no Brasil. Acta Scientiarum. Biological Sciences, 31(3): 327-330.

GUINDON, S. \& GASCUE, S. 2003. A simple, fast and accurate method to estimate large phylogenies by maximum-likelihood". Systematic Biology, 52: 696-704.

HALL, T. 2005. BioEdit v.7.0.5. Biological sequences alignment editor for Windows. Ibis Therapeutics a division of Isis pharmaceuticals http:// www.mbio.nesu.edu/bioefit.html

HARRISON, J.S. 2004. Evolution, biogeography, and the utility of mitochondrial $16 \mathrm{~s}$ and COI genes in phylogenetic analysis os the crab genus Austinixia (Decapoda: Pinnotheridae). Molecular Phylogenetics and Evolution, 30(3): 743-754.

HEPP, L.U.; FORNEL, R.; RESTELLO, R.M; TREVISAN, A.T. \& SANTOS, S. 2012. Intraspecific morphological variation in a freshwater crustacean Aegla plana in 
southern Brazil: Effects of geographical isolation on carapace shape. Journal of Crustacean Biology, 32(4): 511-518.

HUELSENBECK, J.P. \& RONQUIST, F. 2001. MrBayes: Bayesian inference of phylogeny. Bioinformatics, 17(8): 754-755.

IRWIN, D.E.; BENSCH, S. \& IRWIN, J.H. 2005. Speciation by distance in a ring species. Science, 307: 414-416.

IRWIN, D.E.; BENSCH, S. \& PRICE, T.D. 2001. Speciation in a ring. Nature, 409: 333-337.

JESSE, R.; SCHUBART, C.D. \& KLAUS, S. 2010. Identification of a cryptic lineage within Potamon fluviatile (Herbst) (Crustacea: Brachyura: Potamidae). Invertebrate Systematics, 24: 348-356.

KATOH, K. \& TOH, H. 2008. Recent developments in the MAFFT multiple sequence alignment program. Briefings in Bioinformatics, 9: 286-298.

KLAUS, S.; YEO, D.C.J. \& AHYONG, S.T. 2011. Freshwater crab origins-Laying Gondwana to rest. Zoologischer Anzeiger, 250: 449-456.

KEENAN, C.P.; DAVIE, P.J.F \& MANN, D.L. 1998. A revision of the genus Scylla de Haan, 1833 (Crustacea: Decapoda: Brachyura: Portunidae). Raffles Bulletin of Zoology, 46(1): 217-146.

KITAURA, J.; NISHIDA, M. \& WADA, K. 2002. Genetic and behavioral diversity in the Macrophthalmus japonicus species complex (Crustacea: Brachyura: Ocypodidae). Marine Biology, 140(1): 1-8.

LAI, J.C.Y.; NG, P.K.L. \& DAVIE, P.J.F. 2010. A revision of the Portunus pelagicus (Linnaeus, 1758) species complex (Crustacea: Brachyura, Portunidae), with the recognition of four species. Raffles Bulletin of Zoology, 58(2): 199-237. 
LATREILLE, P.A. 1825. Families naturelles du règne animal, exposées succinnctement et dans un ordre analytique, avec I' indication de leurs genres. Paris: J.-B. Baillière. 570 p.

LATREILLE, P.A. 1828. Trichodactyle, Trichodactylus. In: Encyclopédie Méthodique. Histoire naturelle. Entomologie, ou Histoire Naturelle des Crustacés, des Arachnides et des Insectes. Paris: Agasse, 10: p.705.

LEFÉBURE, T.; DOUADY, C.J.; GOUY, M. \& GIBERT, J. 2006. Relationship between morphological taxonomy and molecular divergence within Crustacea: Proposal of a molecular threshold to help species delimitation. Molecular Phylogenetics and Evolution, 40(2): 435-447.

LIMA, C.C.U.; BOAS, G.S.V. \& BEZERRA, F.H.R. 2006. Faciologia e análise tectônica preliminar da formação barreiras no litoral sul do estado da Bahia, Brasil. Revista do Instituto de Geociências - USP, 6(2): 71-80.

LIU, M.Y. ; CAI, Y.X. \& TZENG, C.S. 2007. Molecular systematics of the freshwater prawn genus Macrobrachium Bate, 1868 (Crustacea: Decapoda: Palaemonidae) inferred from mtDNA sequences, with emphasis on East Asian species. Zoological Studies, 46(3): 272-289.

MAGALHÃES, C. 1991. Revisão taxonômica dos caranguejos dulcícolas da família Trichodactilydae (Crustacea: Decapoda: Brachyura). 175f. Tese de doutorado. Universidade de São Paulo - SP.

MAGALHÃES, C. 1999b. Crustáceos Decápodos. In: ISMAEL, D.; VALENTI, W.C. \& MATSUMURA-TUNDISI, T. (eds.). Biodiversidade do Estado de São Paulo, Brasil. Invertebrados de água doce. São Paulo: FAPESP. p. 127-133.

MAGALHÃES, C. 2003. Famílias Pseudothelphusidae e Trichodactylidae. In: MELO, G.A.S. (ed). Manual de identificação dos Crustacea Decapoda de água doce do Brasil. São Paulo: Loyola. p. 143-287. 
MAGALHÃES, C. \& TÜRKAY, M. 1996a. Taxonomy of the neotropical freshwater crab family Trichodactylidae, I: the generic system with description of some new genera (Crustacea: Decapoda: Brachyura). Senckenbergiana Biologica, $75(1 / 2): 63-95$.

MAGALHÃES, C. \& TÜRKAY, M. 1996b. Taxonomy of the neotropical freshwater crab family Trichodactylidae II: the genera Forsteria, Melocarcinus, Sylviocarcinus and Zilchiopsis (Crustacea: Decapoda: Brachyura). Senckenbergiana Biologica, 75(1/2): 97-130.

MAGALHÃES, C. \& TÜRKAY, M. 1996c. Taxonomy of the neotropical freshwater crab family Trichodactylidae III: the genera Fredilocarcinus and Goyazana (Crustacea: Decapoda: Brachyura). Senckenbergiana Biologica, 75(1/2): 131142.

MALAY, M.C.D.; KOMAI, T. \& CHAN, T.I. 2009. A new cryptic species in the “Calcinus anani Poupin \& McLaughlin, 1998” species complex (Decapoda: Anomura: Diogenidae): evidence from colouration and molecular genetics. Zootaxa, 3367: 165-175.

MANTELATTO F.L.; PARDO, L.M; PILEGGI, L.P. \& FELDER, D.L. 2009 a. Taxonomic re-examination of the hermit crab species Pagurus forceps and Pagurus comptus (Decapoda: Paguridae) by molecular analysis. Zootaxa, 2133: 20-32.

MANTELATTO, F.L.; ROBLES, R.; BIAGI, R. \& FELDER, D.L. 2006. Taxonomic and distributional status based on molecular data for hermit crab genera Loxopagurus Forest, 1964, and Isocheles Stimpson, 1858 (Decapoda, Anomura, Diogenidae). Zoosystema, 28(2): 495-506. 
MANTELATTO, F.L.; ROBLES, R. \& FELDER, D.L. 2007. Molecular phylogeny of the Western Atlantic species of the genus Portunus (Crustacea, Brachyura, Portunidae). Zoological Journal of the Linnean Society, 150(1): 211-220.

MANTELATTO F.L.; ROBLES, R.; SCHUBART C.D. \& FELDER, D.L. 2009 b. Molecular phylogeny of the genus Cronius Stimpson, 1860, with reassignment of C. tumidulus and several American species of Portunus to the genus Achelous De Haan, 1833 (Brachyura: Portunidae). In: MARTIN, J.W.; CRANDALL, K.A. \& FELDER, D.L. (eds). Crustacean Issues: Decapod Crustacean Phylogenetics. Taylor and Francis/CRC Press, Boca Raton, 18: 567-579.

MARTENS, E. von. 1869. Siidbrasilianische Suss-und Brackwasser-Crustaceen nach den Sammlungen des Dr. Reinh, Hensel. Archiv für Naturgeschichte 35(1):1-37.

MAYR, E. 1977. Populações, espécies e evolução. São Paulo: Nacional e EDUSP. 485p.

MELLO, G.A.S. 1967. Diferenciação geográfica e dimorfismo sexual de Trichodactylus (Trichodactylus) fluviatilis Latreille, 1828 (Crustacea, Brachyura). Papéis Avulsos de Zoologia, 20(3): 13-44.

MILNE-EDWARDS, A. 1869. Révision des genres Trichodactylus, Sylviocarcinus et Dilocarcinus et description de qualques espèces nouvelles qui s'y rattachent. Annlas Society Entomology France, 9: 170-178.

MILNE EDWARDS, H. 1837. Histoire naturelle des Crustacés, comprenant I' anatomie, la physiologie et la classification de ces animaux. Paris: Librairie Encyclopédique de Roret, 552 p.

MILNE EDWARDS, H. 1853. Memoire sur la famille des Ocypodiens. Annales des Sciences Naturelles , 20(3): 163-228.

MISHLER, B.D. \& THERIOT, E.C. 2000. The Phylogenetic Species Concept (sensu Mishler and Theriot): Monophyly, Apomorphy, and Phylogenetic Species 
Concepts. In: WHEELER, Q.D. \& MEIER, R. (eds). Species concepts and phylogenetic theory: a debate. New York: Columbia University Press. p. 44-54.

MOREIRA, C. 1901. Contribuições para o conhecimento da fauna brasileira. Crustáceos do Brazil. Archivos Museu Nacional do Rio de Janeiro, 11: 1-151.

MOREIRA, C. 1913. Historia Natural. Zoologia. Crustáceos. Publicações do Conselho Nacional de Proteção ao Indío, 13 (Anexo5). 21 p.

MOSSOLIN, E.C. \& MANTELATTO, F.L. 2008. Taxonomic and distributional results of a freshwater crab fauna survey (Family Trichodactylidae) on São Sebastião Island (Ilhabela), South Atlantic, Brazil. Acta Limnologica Brasiliensia, 20(2): 125-129.

MULLER, F. 1892. Trichodactylus, siri de agua doce, sem metamorfose. Archivos do Museu Nacional do Rio de Janeiro, 8: 125-133.

NEGRI, M.; PILEGGI, L.G. \& MANTELATTO, F.L. 2012. Molecular barcode and morphological analyses reveal the taxonomic and biogeographical status of the striped-legged hermit crab species Clibanarius sclopetarius (Herbst, 1796) and Clibanarius vittatus (Bosc, 1802) (Decapoda: Diogenidae). Invertebrate Systematics, 26 (5/6): 561-571.

NG, P.K.L. 1988. The Freshwater Crabs of Peninsular Malaysia and Singapore. Department of Zoology, National University of Singapore, Shinglee Press, Singapore. $156 \mathrm{p}$.

NG, P.K.L.; GUINOT, D. \& DAVIE, P.J.F. 2008. Systema Brachyurorum: Part I. An annotated checklist of extant brachyuran crabs of the world. The Raffles Bulletin of Zoology, 17: 1-286.

NG, P.K.L. \& YEO, D.C.J. 2007. Malaysian freshwater crabs: conservation prospects and challenges. In: CHUA, L. (ed.), Proceedings of the Seminar on the Status of Biological Diversity in Malaysia and Threat Assessment of Plant Species in 
Malaysia, 28-30 June 2005. Forest Research Institute Malaysia, Kepong, p. 95120.

NUNES, F.C.; SILVA, E.F. \& BOAS, G.S.V. 2011. Grupo Barreiras: características, gênese e evidências de neotectonismo. Rio de Janeiro: Embrapa Solos. 31 p.

OLIVEIRA, D. 2010. Capturas fluviais como evidências da evolução do relevo: uma revisão bibliográfica. Revista do Departamento de Geografia, 20: 37-50.

ORTMANN, A. 1897. Carcinologische Studien. Zoologische Jahrberichter Systematische, 10(3): 258-372.

PFENNINGER, M. \& SCHWENK, K. 2007. Cryptic animal species are homogeneously distributed among taxa and biogeographical regions. BMC Evolutionary Biology, 7: 121.

PILEGGI, L.G. \& MANTELATTO, F.L. 2010. Molecular phylogeny of the freshwater prawn genus Macrobrachium (Decapoda, Palaemonidae) with emphasis on the relationships among American species and the status of the type species. Invertebrate Systematics, 24: 194-208.

PRETZMANN, G. 1968b. Die Familie Trichodactylidae (Milne-Edwards 1853) Smith 1870 (Vorläufige Mitteilung). Entomologisches Nachrichtenblatt, 15(7-8): 7076.

RAGIONIERI, L.; FRATINI, S.; VANNINI, M. \& SCHUBART, C.D. 2009. Phylogenetic and morphometric differentiation reveal geographic radiation and pseudo-cryptic speciation in a mangrove crab from the Indo-West Pacific. Molecular Phylogenetics and Evolution, 52: 825-834.

RATHBUN, M.J. 1906b. Les crabes d'eau douce (Potamonidae). Nouvelles Archives du Muséum d'Histoire Naturelle, 8(4): 33-122. 
Revenga, C.; CAMBell, I.; ABell, R.; VIlliers, P. \& BRYER, P. 2005. Prospects for monitoring freshwater ecosystems towards the 2010 targets. Philosophical Transactions, da Royal Society B, 360: 397-413.

RIDLEY, M. 2006. Evolução. 3. ed. Porto Alegre: Artmed. 752p.

ROCHA, S.S. \& BUENO, S.L.S. 2004. Crustáceos decápodes de água doce com ocorrência no Vale do Ribeira de Iguape e rios costeiros adjacentes, São Paulo, Brasil. Revista Brasileira de Zoologia, 21: 1001-1010.

RODRÍGUEZ, G. 1981. Decapoda. In: HURLBERT, S.H.; RODRÍGUEZ, G. \& SANTOS, N.D. (eds.), Aquatic Biota of Tropical South America, Part I: Arthropoda. San Diego, San Diego State University, 41-51 p.

RODRÍGUEZ, G. 1992. Les crabes d'eau douce d'Amerique. Famile des Pseudothelphusidae. Orstom, 22: 1-223.

RODRÍGUEZ, G. \& MAGALHÃES, C. 2005. Recent advances in the biology of the neotropical freshwater crabs family Pseudothelphusidae (Crustacea, Decapoda, Brachyura). Revista Brasileira de Zoologia, 22: 354-365

ROSSI, N. \& MANTELATTO, F.L. 2013. Molecular analysis of the freshwater prawn Macrobrachium olfersii (Decapoda, Palaemonidae) supports the existence of a single species throughout its distribution. PLoS ONE 8(1): e54698. doi: $10.1371 /$ journal.pone.0054698

SARMENTO-SOARES, L.M.; MAZZONI, R. \& MARTINS-PINHEIRO, R.F. 2009. A fauna de peixes na bacia do Rio Jucuruçu, leste de Minas Gerais e extremo Sul da Bahia. Pan-American Journal of Aquatic Sciences, 4(2): 193-207.

SCHUBART, C.D.; CONDE, J.E.; CARMONA-SUÁREZ, C.; ROBLES, R. \& FELDER, D.L. 2001a. Lack of divergence between 16S mtDNA sequences of the swimming crabs Callinectes bocourti and C. maracaiboensis (Brachyura: Portunidae) from Venezuela. Fisheries Bulletin, 99(3): 475-481. 
SCHUBART, C.D.; CUESTA, J.A. \& RODRÍGUEZ, A. 2001b. Molecular phylogeny of the crab genus Brachynotus (Brachyura: Varunidae) based on the $16 \mathrm{~S}$ rRNA gene. Hydrobiologia, 449(1): 41-46.

SCHUBART, C.D. \& HUBER, M.G.J. 2006. Genetic comparisons of German populations of the stone crayfish, Austropotamobius torrentium (Crustacea: Astacidae). Bulletin Français de la Pêche et de la Pisciculture, 380-381: 10191028.

SCHUBART, C.D. \& KOLLER, P. 2005. Genetic diversity of freshwater crabs (Brachyura: Sesarmidae) from central Jamaica with description of a new species. Journal of Natural History, 39(6): 469-481.

SCHUBART, C.D.; NEIGEL, J.E. \& FELDER, D.L. 2000. Use of the mitochondrial 16S rRNA gene for phylogenetic and population studies of Crustacea. Crustacean Issues, 12: 817-830.

SCHUBART C.D.; REIMER, J. \& DIESEL, R. 1998a. Morphological and molecular evidence for a new endemic freshwater crab, Sesarma ayatum sp. n., (Grapsidae, Sesarminae) from eastern Jamaica. Zoologica Scripta, 27(4): 373-380.

SCHUBART, C.D.; SANTL, T. \& KOLLER, P. 2008. Mitochondrial patterns of intraand interspecific differentiation among endemic freshwater crabs of ancient lakes in Sulawesi. Contributions to Zoology, 77(2): 83-90.

SCHWANDER, T. \& LEIMAR, O. 2011. Genes as leaders and followers in evolution. Trends in Ecology and Evolution, 26(3): 143-151.

SMITH, S.I. 1869. Notice of the Crustacea collected by Prof. C.F. Hartt on the coast of Brazil in 1867. Transactions of the Connecticut Academy of Arts and Sciences, 2: $1-42$. 
STAMATAKIS, A. 2006. RAxML-VI-HPC: Maximum Likelihood-based phylogenetic analyses with thousands of taxa and mixed models. Bioinformatics, 22(21): 2688-2690.

STERNBERG, R. von \& CUMBERLIDGE, N. 2001. Notes on the position of the true freshwater crabs within the brachyrhynchan Eubrachyura (Crustacea: Decapoda: Brachyura). Hydrobiologia, 449: 2 1-39.

STERNBERG, R. von \& CUMBERLIDGE, N. 2003. Autapomorphies of the endophragmal system in Trichodactylidae freshwater crabs (Crustacea: Decapoda: Eubrachyura). Journal of Morphology, 256: 23-28.

STERNBERG, R.; CUMBERLIDGE, N. \& RODRÍGUEZ, G. 1999. On the marine sister groups of the freshwater crabs (Crustacea: Decapoda: Brachyura). Journal of Zoological Systematics and Evolutionary Research, 37: 19-38.

STEWART, B.A. 1997b. Morphological and genetic differentiation between populations of river crabs (Decapoda: Potamonautidae) from the Western Cape, South Africa, with a taxonomic re-examination of Gecarcinautes brincki. Zoological Journal of the Linnean Society, 119: 1-21.

TAMURA, K.; PETERSON, D.; PETERSON, N.; STECHER, G.; NEI, M. \& KUMAR, S. 2011. MEGA5: molecular evolutionary genetics analysis using maximum likelihood, evolutionary distance, and maximum parsimony methods. Molecular Biology and Evolution 28(10): 2731-2739.

TANG, B.; ZHOU, K.; SONG, D.; YANG, .G \& DAI, A. 2003. Molecular systematic of the Asian mitten crabs, genus Eriocheir (Crustacea: Brachyura). Molecular Phylogenetics and Evolution, 29(2): 309-316.

TAKANO, B. 2011. Estrutura populacional, crescimento somático e alométrico, biologia reprodutiva e estimativa do tamanho populacional de Aegla perobae Hebling \& Rodrigues, 1977 do município de São Pedro, estado de São Paulo. 
138f. Dissertação de mestrado. Universidade de São Paulo, Instituto de Biociências, São Paulo - SP.

VERGAMINI, F.G. 2009. Análise comparativa entre populações costeiras e continentais do camarão Macrobrachium amazonicum (Heller, 1862) (Crustacea, Palaemonidae) por meio de dados morfológicos e moleculares. 91f. Dissertação de Mestrado. Universidade de São Paulo, Faculdade de Filosofia, Ciências e Letras de Ribeirão Preto, Ribeirão Preto - SP.

VERGamini， F.G.; PIlegGi, L.G. \& MANTElatTO, F.L. 2011. Genetic variability of the Amazon River prawn Macrobrachium amazonicum (Decapoda, Caridea, Palaemonidae). Contributions to Zoology, 80(1): 67-83.

WIMBERGER, P.H. 1992. Plasticity of fish body shape. The effects of diet, development, family and age in two species of Geophagus (Pisces: Cichlidae). Biological Journal of the Linnean Sociely, 45: 197-218.

WHITE, A. 1847a. List of the specimens of Crustacea in the collection of the British Museum. London, 141 p.

YEO, D.C.J.; NG, P.K.L.; CUMBERLIDGE, N.; MAGALHÃES, C.; DANIELS, S.R. \& CAMPOS, M.R., 2008. A global assessment of freshwater crab diversity (Crustacea: Decapoda: Brachyura). Hydrobiologia, 595: 275-286.

YOUNG, C.G. 1900. The Stalk-Eyed Crustacea of British Guiana, West Indies, and Bermuda. London, John M. Watkins, 514p. 


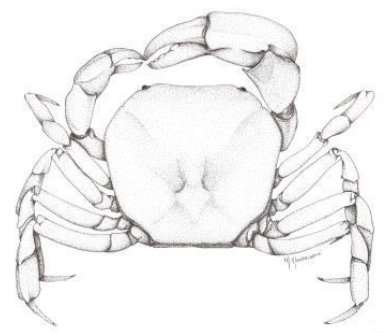

ANEXOS 
ANEXO I - Exemplares do complexo Trichodactylus fluviatilis de diferentes localidades. A - Porto Ferreira, SP. B - Ilhabela, SP. C - Paulistânia, SP. D - Rio de Janeiro, RJ.

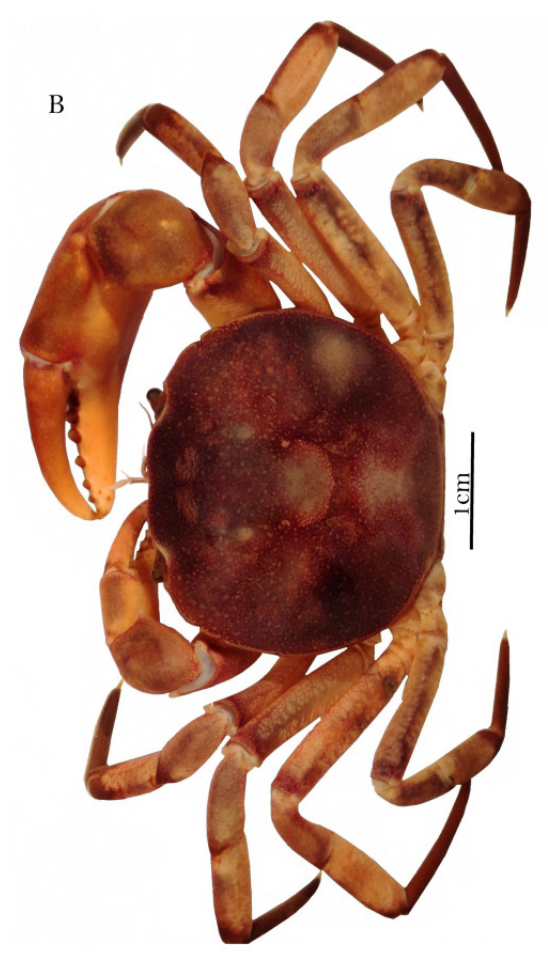

D
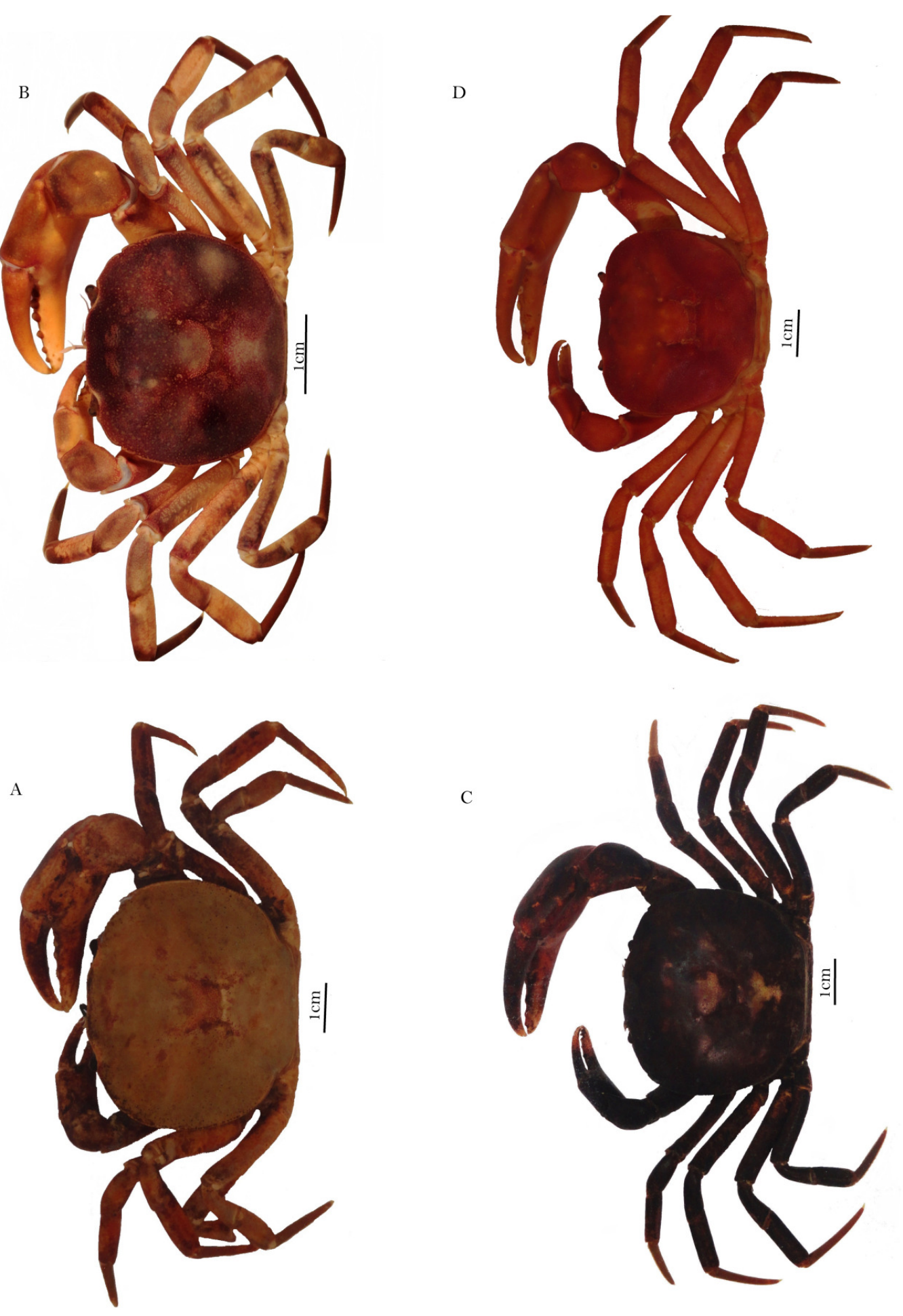
ANEXO II - Exemplares do complexo Trichodactylus fluviatilis de diferentes localidades. A - Cananéia, SP. B - Prado, BA. C - Elísio Medrado, BA. D - Ilhéus, BA.

\section{B}
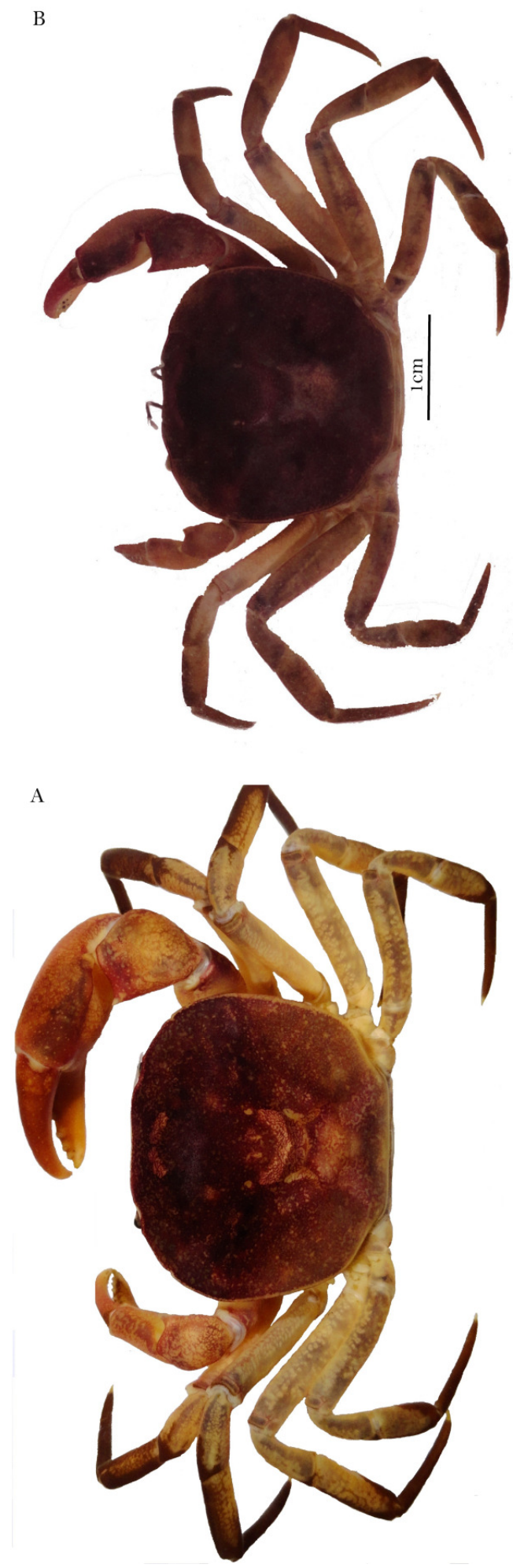
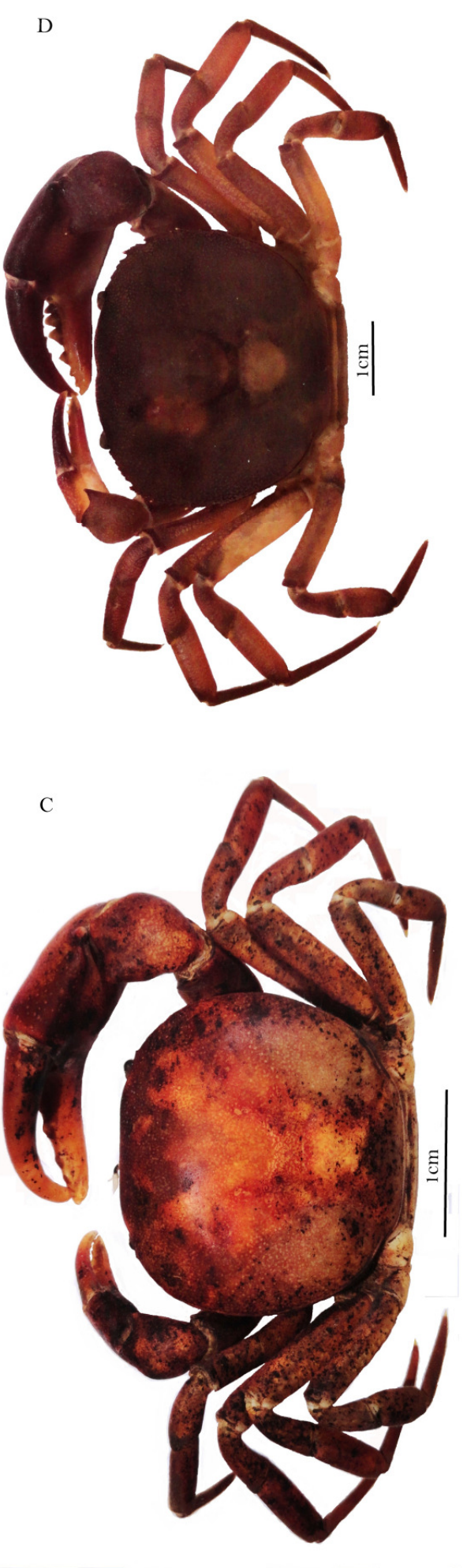
ANEXO III - Exemplares do complexo Trichodactylus fluviatilis de diferentes localidades. A - Serra, ES. B - São José dos Ausentes, RS.

A

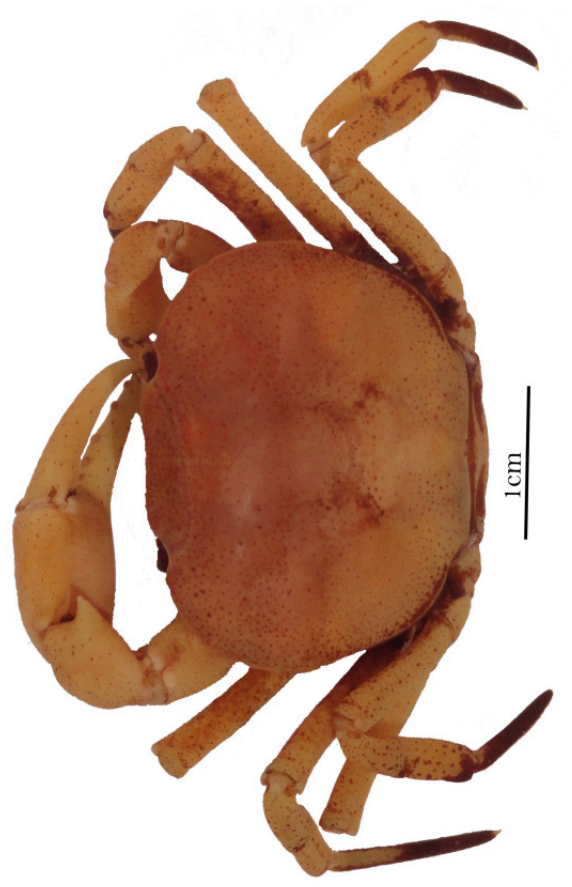

B

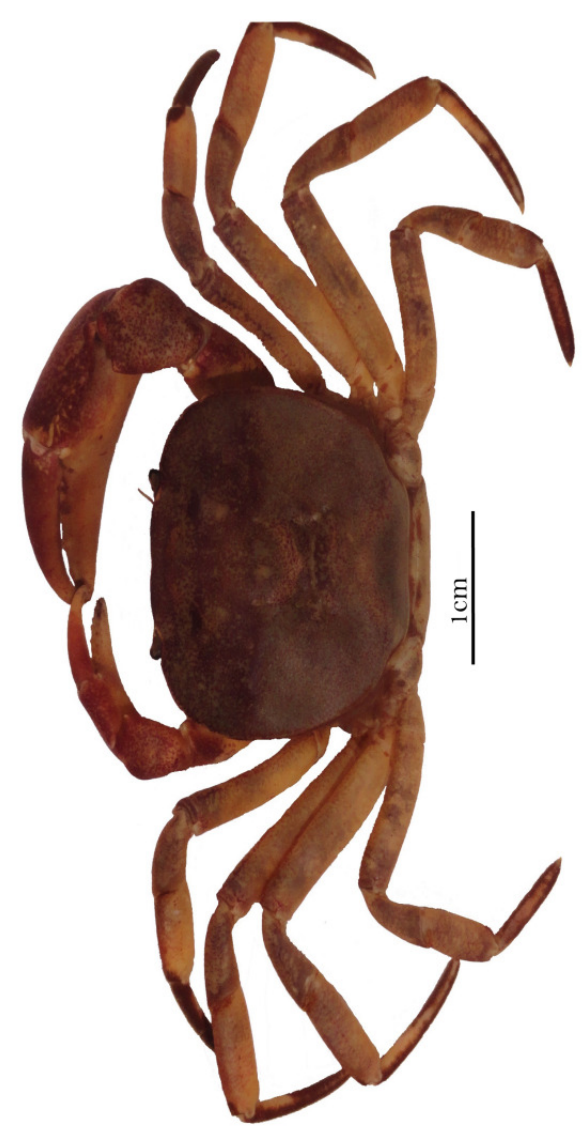

